\title{
Sexe, onderwijs en arbeidsmarkt
}

Citation for published version (APA):

van de Loo, P., \& van der Velden, R. K. W. (1991). Sexe, onderwijs en arbeidsmarkt. Researchcentrum voor Onderwijs en Arbeidsmarkt, Faculteit der Economische Wetenschappen. ROA Working Papers No. 5 https://doi.org/10.26481/umarow.1991005

Document status and date:

Published: 01/01/1991

DOI:

10.26481/umarow.1991005

Document Version:

Publisher's PDF, also known as Version of record

\section{Please check the document version of this publication:}

- A submitted manuscript is the version of the article upon submission and before peer-review. There can be important differences between the submitted version and the official published version of record.

People interested in the research are advised to contact the author for the final version of the publication, or visit the DOI to the publisher's website.

- The final author version and the galley proof are versions of the publication after peer review.

- The final published version features the final layout of the paper including the volume, issue and page numbers.

Link to publication

\footnotetext{
General rights rights.

- You may freely distribute the URL identifying the publication in the public portal. please follow below link for the End User Agreement:

www.umlib.nl/taverne-license

Take down policy

If you believe that this document breaches copyright please contact us at:

repository@maastrichtuniversity.nl

providing details and we will investigate your claim.
}

Copyright and moral rights for the publications made accessible in the public portal are retained by the authors and/or other copyright owners and it is a condition of accessing publications that users recognise and abide by the legal requirements associated with these

- Users may download and print one copy of any publication from the public portal for the purpose of private study or research.

- You may not further distribute the material or use it for any profit-making activity or commercial gain

If the publication is distributed under the terms of Article $25 \mathrm{fa}$ of the Dutch Copyright Act, indicated by the "Taverne" license above, 
Sexe, onderwijs en arbeidsmarkt

ROA-W-1991/5

P.J.E. van de Loo, R.K.W. van der Velden 
SEXE, ONDERWIJS EN ARBEIDSMARKT

ROA-W-1991/5

P.J.E. van de Loo, R.K.W. van der Velden

RESEARCHCENTRUM VOOR ONDERWIJS EN ARBEIDSMARKT

Faculteit der Economische Wetenschappen

Rijksuniversiteit Limburg

Maastricht, december 1991 
CIP-GEGEVENS KONINKLIJKE BIBLIOTHEEK, DEN HAAG

Loo, P.J.E. van de

Sexe, onderwijs en arbeidsmarkt/P.J.E. van de Loo, R.K.W. van der Velden. - Maastricht: Researchcentrum voor Onderwijs en Arbeidsmarkt, Faculteit der Economische Wetenschappen, Rijksuniversiteit Limburg. - (Werkdocument/Researchcentrum voor Onderwijs en Arbeidsmarkt, ISSN 0922-4645; 1991/5)

Met lit. opg.

ISBN 90-5321-085-7 in ringband

Trefw: onderwijs en arbeidsmarkt; vrouwen. 


\section{INHOUDSOPGAVE}

Bladzijde

VOORWOORD

1. INLEIDING

2. PARTICIPATIE OP DE ARBEIDSMARKT 3

2.1. Participatiegraad 3

2.2. Deeltijdarbeid 10

2.3. Werkloosheid 13

3. GESLACHTSSPECIFIEKE SEGREGATIE NAAR OPLEIDING EN BEROEP 15

3.1. Inleiding 15

$\begin{array}{ll}\text { 3.2. Onderwijssegregatie } & 17\end{array}$

3.3. Beroepssegregatie 23

4. WERKGELEGENHEIDSSTRUCTUUR 29

4.1. Dienstverband naar sexe 29

4.2. Aandeel van sexen in groei- en krimpberoepen 31

4.3. Aansluiting tussen opleiding en functieniveau naar sexe 33

5. ARBEIDSMARKTKARAKTERISTIEKEN VROUWENBEROEPEN 36

5.1. Inleiding 36

5.2. Opleidingsprofiel vrouwenberoepen $\quad 39$

5.3. Actuele arbeidsmarktkenmerken vrouwenberoepen 41

5.4. Arbeidsmarktperspectieven vrouwenberoepen 46

6. ARBEIDSMARKTKARAKTERISTIEKEN VROUWENOPLEIDINGEN 48

6.1. Inleiding 48

6.2. Beroepsprofiel vrouwenopleidingen $\quad 49$

6.3. Arbeidsmarktperspectieven vrouwenopleidingen 51

6.4. Actuele arbeidsmarktkenmerken vrouwenopleidingen $\quad 54$

$\begin{array}{ll}\text { 7. BESLUIT } & 61\end{array}$

LITERATUUR 63

BIJLAGE 1. DE BELANGRIJKSTE OPLEIDINGSACHTERGRONDEN VAN DE BEROEPS- 66 BEOEFENAREN IN VROUWENBEROEPEN NAAR SEXE IN 1985

BIJLAGE 2. DE BELANGRIJKSTE BEROEPEN VAN BEROEPSBEOEFENAREN MET EEN 68 VROUWENOPLEIDING ALS OPLEIDINGSACHTERGROND NAAR SEXE IN 1985 


\section{Overzicht tabellen}

1. Participatiegraad naar leeftijd en geslacht tussen 1981 en 1989 in procenten

2. Participatiegraad van vrouwen naar burgerlijke staat tussen 1975 en 1989

3. Participatiegraad van gehuwde vrouwen naar leeftijd van het jongste thuiswonende kind tussen 1975-1985

4. Participatiegraad naar sexe en opleidingsniveau in 1979 en 1985 in procenten

5. Participatiegraad naar sexe en onderwijssoort in 2000 in procenten

6. Participatiegraad naar sexe, hoogst behaalde onderwijsniveau en onderwijsrichting in 1990

7. Wekelijkse arbeidsduur van werkzame vrouwen in loondienst in 1979, 1985 (beiden op basis van AKT), 1987 en 1990 (beiden op basis van EBB) in procenten

8. Reden deeltijdbaan naar sexe van personen in loondienst van 15-64 jaar in 1990 in procenten

9. Werkzame personen naar sexe, CBS-beroepssector en percentage dat in deeltijd werkzaam is (< 35 uur per week) in 1989

10. Werkzame personen naar sexe, CBS-bedrijfssector en percentage dat in deeltijd werkzaam is (< 35 uur per week) in 1989

11. Geregistreerde werklozen absoluut $(x 1000)$ en in \% van de afhankelijke beroepsbevolking 1975-1987

12. Aandeel van gediplomeerden dat het voltijdsonderwijs verlaat naar sexe en onderwijsniveau in 1979-1987 in procenten

13. Onderwijssegregatie-indices (OS) in 1985 in procenten

14. Over- of ondervertegenwoordiging van mannen en vrouwen naar opleiding in de actieve beroepsbevolking in 1985

15. Richtingspecifieke onderwijssegregatie-indices $S$ en $S$ per opleidingsniveau in 1979 en 1985

16. Deelname aan cursussen en bedrijfscursussen naar sexe in 1988 in procenten

17. Geslachtsspecifieke beroepssegregatie-indices s en $S$ naar functieniveau in 1979 en 1985

18. Percentage doorstroming van mannen en vrouwen tussen het moment van indiensttreding en het moment van onderzoek

19. Positie in de werkkring naar sexe in 1979, 1985, 1987 en 1989 in procenten

20. Soort arbeidscontract van personen in loondienst naar sexe in 1983, 1985, 1987 en 1989 in procenten

21. Reden voor tijdelijk contract van personen in loondienst (exclusief militair dienstplichtigen) naar sexe in 1989 in procenten

22. Sterkst groeiende beroepsklassen 1989-1994; absoluut ( $x$ 1000; afgerond) en/of relatief t.o.v. het aantal werkenden in de beroepsklasse in 1989 en percentage vrouwen in die beroepsklasse in 1985

23. Sterkst krimpende beroepsklassen 1989-1994; absoluut (x 1000; afgerond) en/of relatief t.o.v. het aantal werkenden in de beroepsklasse in 1989 en percentage vrouwen in die beroepsklasse in 1985

24. De verdeling van vrouwen over de functieniveaus en het aandeel van vrouwen in 1987 in procenten

25. Werkzame vrouwen in vrouwenberoepen in 1979 en 1985, absoluut (x 1000; afgerond), 
percentage vrouwen in klasse en percentage van totale werkgelegenheid vrouwen

26. Het gewogen functieniveau in 1985 en rangnummer prestigescore in 1982 per vrouwenberoep

27. Aandeel en trend deeltijders in de periode 1979-1985 per vrouwenberoep in procenten

28. Aandeel en trend zelfstandigen in de periode 1979-1985 per vrouwenberoep in procenten

29. Branchespreiding in de periode 1979-1985 per vrouwenberoep

30. Conjunctuurgevoeligheid per vrouwenberoep

31. Procentuele groei van de uitbreidings-, vervangings- en totale vraag in de periode 19891994 per vrouwenberoep

32. Werkzame vrouwen met 'vrouwenopleidingstypen' als opleidingsachtergrond in 1979 en 1985, absoluut (x 1000; afgerond) en in procenten

33. Procentuele groei van de uitbreidings-, vervangings- en totale vraag in de periode 19891994 per vrouwenopleiding

34. Procentuele groei van de instroom op de arbeidsmarkt en het arbeidsmarktperspectief in de periode 1989-1994 per vrouwenopleiding

35. Werkloosheidspercentage in 1990 per vrouwenopleiding

36. Beroepen- en Branchespreiding tussen 1979-1985 per vrouwenopleiding

37. Gemiddeld functieniveau en procentuele onderbenutting in 1985 per vrouwenopleiding

\section{Overzicht figuren}

1. Factoren die volgens empirisch onderzoek van invloed zijn op de arbeidsmarktparticipatie van vrouwen

2. Cumulatieve uitstroom van gediplomeerden uit verschillende opleidingsniveaus van het voltijdsonderwijs naar sexe tussen de studiejaren 1978/' 79 en 1993/'94 in procenten 


\section{VOORWOORD}

In opdracht van het Ministerie van Onderwijs en Wetenschappen ontwikkelt het Researchcentrum voor Onderwijs en Arbeidsmarkt (ROA) het informatiesysteem onderwijsarbeidsmarkt, dat tot doel heeft actuele informatie te verschaffen over de arbeidsmarkt in relatie tot het onderwijs, en prognoses te geven over de aansluiting tussen beide subsystemen op de korte en middellange termijn. Op basis van een nadere analyse van de gegevens uit dit informatiesysteem is het afgelopen jaar een prototype ontwikkeld van een periodiek verschijnend rapport ter ondersteuning van de beleidsvorming door overheid, arbeidsvoorziening, sociale partners en het onderwijsveld. Het is de bedoeling dat dit rapport evenals de daaraan ten grondslag liggende prognoses, tweejaarlijks wordt geactualiseerd.

Een van de hoofdstukken uit dit rapport, 'de arbeidsmarkt naar opleiding en beroep in 1994', is gewijd aan een beschrijving van de rol die de sexe van personen speelt in de relatie tussen het onderwijs en de arbeidsmarkt. Dit werkdocument bevat een nadere beschrijving van deze relatie, waarbij niet alleen gegevens zijn ontleend aan het informatiesysteem onderwijsarbeidsmarkt van het ROA, maar tevens gebruik is gemaakt van aanvullende data uit de arbeidsmarkt- en onderwijsstatistieken van het CBS en literatuur over de relatie tussen sexe, onderwijs- en arbeidsvraagstukken.

Onder leiding van dr. R.K.W. van der Velden heeft drs. P.J.E. van de Loo de gegevens verzameld en de analyse en rapportage verzorgd ten behoeve van voorliggend werkdocument. Bij de verwerking van de gegevens hebben drs. R.J.P. Dekker en P.W.T. Ghijsen assistentie verleend.

Maastricht, december 1991. 


\section{PARTICIPATIE OP DE ARBEIDSMARKT}

\subsection{Participatiegraad}

Sinds de jaren zestig is het percentage vrouwen dat zich meldt op de arbeidsmarkt sterk gestegen (zie o.a. Ministerie van Sociale Zaken en Werkgelegenheid, 1990, blz. 17-20; BruynHundt, 1988, blz. 33-35). Deze participatie op de arbeidsmarkt wordt meestal uitgedrukt in de zogenaamde 'participatiegraad', ook wel 'deelnemingspercentage' genoemd ${ }^{4}$. Mannen en vrouwen zijn wat betreft hun participatie op de arbeidsmarkt in de afgelopen decennia in belangrijke mate naar elkaar toegegroeid. Immers, in 1960 was het deelnemingspercentage voor mannen 90,4 en voor vrouwen 25,6, terwijl in 1986 deze percentages respectievelijk 76,4 en 43,5 bedroegen (Bruyn-Hundt, 1988, blz. 33). Bij de mannen is de participatiegraad gedaald door enerzijds een langere scholing en anderzijds een toename van het aantal arbeidsongeschikten en - recent - een veelvuldig gebruik van regelingen die vervroegd uittreden mogelijk maken (de zogenaamde 'VUT'). Daarentegen is de deelnemingsgraad bij de vrouwen, ondanks de langere scholing, juist sterk gestegen door de toename van het aantal gehuwde vrouwen dat betaald werk heeft of zoekt. Vooral bij jonge vrouwen is sprake van een opmerkelijke stijging van de participatiegraad (Bruyn-Hundt, 1988, blz. 33).

Uit empirisch onderzoek blijkt, dat een groot aantal factoren de beslissing van vrouwen omtrent een eventuele arbeidsparticipatie kan beïnvloeden (Van der Laan en Van den Bout, 1990). Deze factoren kunnen samenhangen met individuele eigenschappen van vrouwen, zoals de leeftijd, het hebben van (een bepaald aantal) kinderen en de opleidingsachtergrond, maar ook met de structuur van de (regionale) arbeidsmarkt, evenals met institutionele factoren, waarbij men kan denken aan zaken zoals kinderopvang en (kostwinnerstoeslagen in) het belastingstelsel. Onderstaand figuur geeft een overzicht van deze factoren.

In deze paragraaf zal worden ingegaan op de relaties tussen sexe, arbeidsmarktparticipatie en respectievelijk leeftijd, burgerlijke staat, kindertal, leeftijd van het jongste thuiswonende kind en hoogst behaalde onderwijsdiploma naar opleidingsniveau en opleidingsrichting. Deze factoren hebben onderstaande figuur overziend allen betrekking op individuele eigenschappen van vrouwen, c.q. van de huishoudingen waartoe deze vrouwen behoren.

4. Het gaat hier om de beroepsbevolking (d.w.z. de werkzame personen en werkzoekenden) gedeeld door de gehele bevolking, beiden voor zover tussen de 15 en 64 jaar (x 100\%). 
Figuur 1. Factoren die volgens empirisch onderzoek van invloed zijn op de arbeidsmarktparticipatie van vrouwen

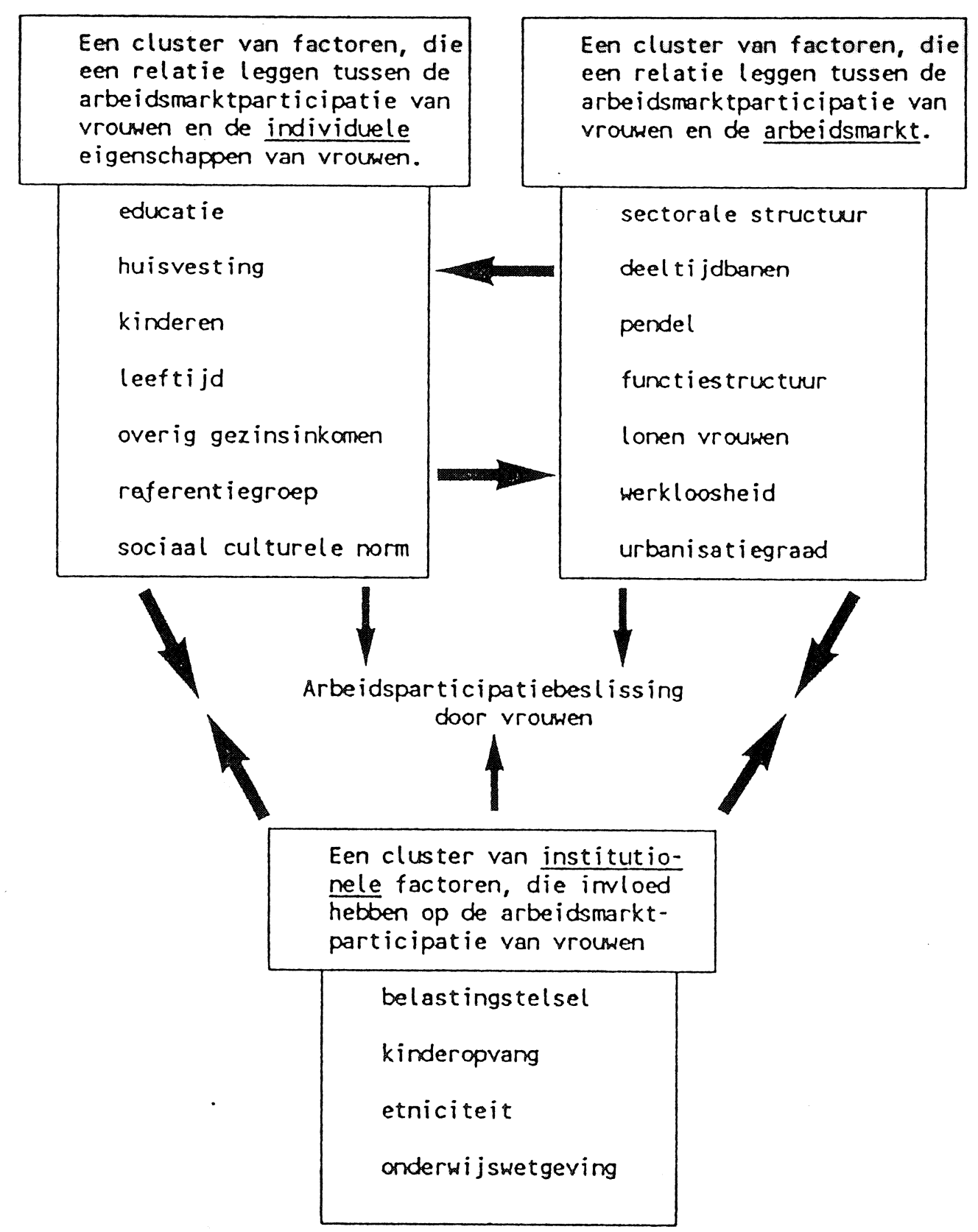

Bron: Van der Laan en Van den Bout, 1990, blz. 4 
$-5-$

Tabel 1. Participatiegraad ${ }^{5}$ naar leeftijd en geslacht tussen 1981 en 1989 in procenten

\begin{tabular}{|c|c|c|c|c|c|}
\hline & 1981 & 1985 & 1987 & 1987 & 1989 \\
\hline \multicolumn{6}{|l|}{ mannen } \\
\hline 15-19 jaar & 28 & 22 & 23 & 41 & 43 \\
\hline 20-24 jaar & 77 & 75 & 73 & 80 & 80 \\
\hline 25-29 jaar & 93 & 93 & 92 & 95 & 95 \\
\hline 30-34 jaar & 97 & 97 & 97 & 97 & 97 \\
\hline 35-39 jaar & 97 & 97 & 96 & 97 & 97 \\
\hline 40-44 jaar & 95 & 95 & 96 & 95 & 96 \\
\hline 45-49 jaar & 91 & 91 & 92 & 92 & 92 \\
\hline 50-54 jaar & 86 & 84 & 82 & 85 & 86 \\
\hline 55-59 jaar & 73 & 70 & 68 & 69 & 69 \\
\hline $60-64$ jaar & 46 & 37 & 31 & 34 & 30 \\
\hline totaal & 78 & 77 & 76 & 80 & 81 \\
\hline \multicolumn{6}{|l|}{ vrouwen } \\
\hline 15-19 jaar & 31 & 24 & 26 & 41 & 40 \\
\hline 20-24 jaar & 71 & 71 & 71 & 75 & 76 \\
\hline 25-29 jaar & 50 & 60 & 64 & 66 & 68 \\
\hline 30-34 jaar & 40 & 46 & 48 & 55 & 59 \\
\hline 35-39 jaar & 43 & 47 & 48 & 56 & 60 \\
\hline 40-44 jaar & 40 & 47 & 50 & 54 & 57 \\
\hline 45-49 jaar & 33 & 40 & 42 & 49 & 51 \\
\hline 50-54 jaar & 26 & 31 & 32 & 38 & 39 \\
\hline 55-59 jaar & 18 & 20 & 20 & 23 & 25 \\
\hline $60-64$ jaar & 9 & 8 & 6 & 10 & 11 \\
\hline totaal & 39 & 42 & 44 & 50 & 52 \\
\hline
\end{tabular}

Bron: Ministerie van Sociale Zaken en Werkgelegenheid, 1990

Uit bovenstaande tabel die de participatiegraad naar leeftijd en geslacht weergeeft voor de periode $1981-1989$ is een aantal conclusies af te leiden. Ten eerste blijkt het verschil tussen beide sexen zich vooral vanaf het $25 \mathrm{e}$ levensjaar te manifesteren; de leeftijd waarna vrouwen de zorg voor hun (eerste) kind(eren) op zich gaan nemen. Op de tweede plaats blijkt de participatie van jongeren, meer bij mannen dan bij vrouwen, te zijn gedaald. Deze daling is, zoals gezegd, het gevolg van het feit, dat jongeren steeds langer naar school gaan. De hoge participatiegraad onder jongeren tussen 1987 en 1989, die zijn gebaseerd op gegevens uit de EBB, is overigens louter toe te schrijven aan het feit, dat in de EBB personen (lees: scholieren, studenten en huisvrouwen) die slechts een paar uur per jaar betaald werk verrichten, in tegenstelling tot de AKT, tot de beroepsbevolking worden gerekend. De dalende participatie van mannen blijkt aan de ene kant dus de jongeren te betreffen en aan de andere kant juist mannen van 50 jaar of ouder, die door VUT-regelingen of arbeidsongeschiktheid de arbeidsmarkt

5. Het gaat hier om de beroepsbevolking als percentage van de overeenkomstige leeftijdsgroep in de bevolking. De gegevens zijn t/m 1987 berekend op basis van standsgegevens per 1 januari uit de AKT en vanaf 1987 op basis van jaargemiddelden uit de EBB. 
(vervroegd) verlaten. De participatie van mannen tussen de 25 en 50 is tussen 1981 en 1989 nagenoeg niet veranderd. Bij de vrouwen daarentegen heeft de stijgende arbeidsmarktparticipatie zich met name in de middelste leeftijdsklassen voltrokken. Dus in de periode dat de meeste vrouwen kinderen (kunnen) krijgen.

Tabel 2. Participatiegraad ${ }^{6}$ van vrouwen naar burgerlijke staat tussen 1975 en 1989

\begin{tabular}{lcccc}
\hline Jaar & Ongehuwd & Gehuwd & Gescheiden/Weduwe & Totaal \\
\hline & & 17 & -- & 24 \\
1975 & -- & 21 & 5 & 30 \\
1981 & 54 & 22 & 32 & 32 \\
1985 & 53 & 25 & 35 & 36 \\
1989 & 54 & 27 & & 36 \\
\hline
\end{tabular}

Bron: CBS/Ministerie Sociale Zaken en Werkgelegenheid

Ongehuwde vrouwen ${ }^{7}$ blijken een veel hogere participatiegraad te hebben dan hun gehuwde, respectievelijk gescheiden of weduwe geworden sexegenoten. De participatiegraad op basis van de beroepsbevolking in strikte zin is bij de gehuwde vrouwen, evenals bij de gescheiden vrouwen en weduwen de afgelopen tien tot vijftien jaar fors gestegen, terwijl deze bij hun ongehuwde sexegenoten vrijwel niet is veranderd. De verschillen tussen vrouwen wat betreft hun deelname op de arbeidsmarkt neemt naar burgerlijke staat dus af.

Tabel 3. Participatiegraad van gehuwde vrouwen naar leeftijd van het jongste thuiswonende kind tussen 1975-1985

Leeftijd jongste thuiswonende kind
0-3 jaar
4-5 jaar
6 jaar en ouder
geen kinderen thuis totaal

$\begin{array}{llllll}1975 & 12 & 21 & 21 & 28 & 22 \\ 1977 & 13 & 21 & 23 & 30 & 24 \\ 1979 & 16 & 25 & 25 & 31 & 26 \\ 1981 & 19 & 29 & 30 & 32 & 29 \\ 1983 & 23 & 30 & 32 & 33 & 32 \\ 1985 & 25 & 30 & 32 & 32\end{array}$

Bron: SCP, 1988

6. Het gaat hier om de beroepsbevolking in strikte zin als percentage van de overeenkomstige categorie in de bevolking. De beroepsbevolking in strikte zin betreft alleen degenen die meer dan 20 uur per week (willen) werken. Tot 1981 gold overigens een grens van 25 uur per week.

7. Ook voor mannen geldt dat gehuwden een lagere participatie hebben dan ongehuwden. Het verschil is bij hen alleen veel kleiner $(87 \%$ versus $88,5 \%)$. 
Uit bovenstaande tabel is ondermeer het effect van de leeftijd van het jongste thuiswonende kind op de participatie van gehuwde vrouwen af te lezen. Moeders met peuters hebben verhoudingsgewijs een lage participatiegraad. Ook blijkt uit deze tabel, dat het hebben van (jonge) kinderen voor vrouwen steeds minder vaak de reden is om niet aan het arbeidsproces deel te nemen. Al is de combinatie van jonge kinderen en betaald werk buitenshuis voor veel vrouwen nog steeds niet erg aantrekkelijk (zie ook Brouns en Schokker, 1990, blz. 28); slechts $25 \%$ van de moeders met een kind in de leeftijd van 0-3 jaar verrichtte namelijk in 1985 betaalde arbeid. Een ander opmerkelijk punt in deze tabel betreft de lage participatie van gehuwde vrouwen zonder thuiswonende kinderen in het algemeen en de geringe toename in de participatie van deze groep in de periode 1975-1985. Zaken als (de onvoldoende) kwaliteit van (vrouwen)arbeid, maatschappelijke waarden en normen over de taken van getrouwde vrouwen, evenals het zogenaamde 'discouraged worker effect' kunnen hierbij een rol spelen.

Tabel 4. Participatiegraad ${ }^{8}$ naar sexe en opleidingsniveau in 1979 en 1985 in procenten

\begin{tabular}{lcccc}
\hline & \multicolumn{2}{c}{ Mannen } & \multicolumn{2}{c}{ Vrouwen } \\
Opleidingsniveau & 1979 & 1985 & 1979 & 1985 \\
\hline \multirow{2}{*}{ Basisonderwijs } & 81,8 & 76,0 & 22,8 & 27,1 \\
Mavo & 94,3 & 89,2 & 46,3 & 45,7 \\
LBO & 92,9 & 90,6 & 36,5 & 42,7 \\
HAVO/VWO & 96,4 & 93,9 & 58,8 & 65,6 \\
MBO & 95,6 & 93,0 & 54,3 & 59,2 \\
HBO & 97,0 & 94,3 & 64,9 & 73,0 \\
WO & 98,6 & 96,5 & 78,8 & 85,9 \\
\hline
\end{tabular}

Bron: CBS/ROA

De stijgende deelname van vrouwen op de arbeidsmarkt kan, blijkens een analyse van het Centraal Plan Bureau (CPB, 1987, blz. 24-27), voor circa de helft worden toegeschreven aan de toename van het opleidingsniveau van de vrouwen en voor de andere helft aan een stijging van de participatie binnen onderwijscategorieën. Zoals ook valt af te lezen uit bovenstaande tabel over de participatie van beide sexen naar opleidingsniveau, bestaat er, meer nog voor vrouwen dan voor mannen, een positief verband tussen opleidingsniveau en deelnemingspercentage. Overigens kan men ook in deze tabel de dalende participatie bij mannen en de stijgende participatie van vrouwen constateren. Met uitzondering van de participatiegraad van vrouwen met MAVO als hoogst genoten onderwijs, waarbij de participatie tussen 1979 en 1985 namelijk licht is gedaald, is dit een trend die zich op alle onderwijsniveaus manifesteert. De dalende participatie bij mannen heeft zich relatief meer voorgedaan bij mannen met een lager onderwijsprofiel, terwijl de toegenomen participatie onder vrouwen daarentegen in verhouding

8. De participatiegraad betreft hier de beroepsbevolking (de werkenden en werkzoekenden) als percentage van de potentiële beroepsbevolking (bevolking van 15 tot 65 jaar, voor zover zij geen scholier of student zijn). 
meer onder de middelbare en hoger opgeleide vrouwen heeft plaatsgevonden.

Tabel 5. Participatiegraad ${ }^{9}$ naar sexe en onderwijssoort in 2000 in procenten

Participatie

Onderwijssoort Mannen Vrouwen

$\begin{array}{lll}\text { Lager onderwijs } & 77 & 34 \\ \text { Uitgebreid lager onderwijs } & 91 & 48 \\ \text { Middelbaar onderwijs } & 92 & 67 \\ \text { Semi-hoger onderwijs } & 89 & 75 \\ \text { Hoger onderwijs } & 94 & 84 \\ & & \\ \text { Totaal } & 89 & 58\end{array}$

Bron: CPB, 1987, blz. 24-25.

Het CPB (CPB-W-1987, blz. 24-27) heeft bij het opstellen van prognoses over het arbeidsaanbod eveneens toekomstige participatiegraden voor zowel mannen als vrouwen berekend (zie tabel 5). De stijgende participatie onder vrouwen in het verleden wordt door hen in het jaar 2000 tot $58 \%$ doorgetrokken, terwijl de participatiegraad van de mannen op het niveau van 1985, namelijk $89 \%$, wordt bevroren. Bij deze prognoses gaat het CPB ook uit van een stijgende deelname bij een toenemend opleidingsniveau (met uitzondering van mannen op semi-hoog opleidingsniveau).

Zoals uit tabel 6 naar voren komt, is arbeidsmarktparticipatie niet alleen afhankelijk van genoten opleidingsniveau, maar tevens van de opleidingsrichting die men heeft gevolgd. De participatieverschillen tussen mannen en vrouwen blijken groter bij afgestudeerden van het beroepsonderwijs, dan bij degenen die algemeen of wetenschappelijk onderwijs als hoogste onderwijskwalificatie hebben. Binnen de onderscheiden opleidingsniveaus blijkt de gevolgde richting een grotere invloed te hebben op de participatie van vrouwen dan die van mannen. Over het algemeen participeren vrouwen met een agrarische, economisch-administratieve, commerciële, paramedische of sociaal-culturele opleidingsachtergrond naar verhouding vaker op de arbeidsmarkt dan hun sexegenoten met een onderwijzende, verzorgende of technische ${ }^{10}$ opleidingskwalificatie. De eerste groep vrouwen lijkt zich vooral te hebben geschoold voor, al dan niet typische vrouwenberoepen in kantoren, winkels, zorgsector en landbouw. De tweede groep lijkt vooral te bestaan uit vrouwen die een scholing hebben genoten die past bij het beeld van vrouw als 'moeder en huisvrouw'.

9. Het gaat hier om de beroepsbevolking als percentage van de potentiële beroepsbevolking.

10. Hierbij moet wel worden gerealiseerd dat in de gehanteerde Standaard Onderwijs Indeling (SOI) van het CBS de confectie-opleidingen bij het technisch onderwijs zijn ingedeeld. 
$-9-$

Tabel 6. Participatiegraad ${ }^{11}$ naar sexe, hoogst behaalde onderwijsniveau en onderwijsrichting in 1990

Participatie

\begin{tabular}{|c|c|c|}
\hline Opleiding & Mannen & Vrouwen \\
\hline BO & 65,7 & 30,7 \\
\hline MAVO & 62,6 & 47,0 \\
\hline LBO & 86,3 & 47,8 \\
\hline agrarisch & 82,8 & 61,5 \\
\hline technisch & 86,4 & 35,2 \\
\hline economisch-administratief, commercieel & 87,5 & 60,3 \\
\hline verzorging & 86,7 & 45,7 \\
\hline overig & 87,9 & 48,6 \\
\hline HAVO/VWO & 62,1 & 55,8 \\
\hline MBO & 89,5 & 66,8 \\
\hline onderwijzend & 90,0 & 59,5 \\
\hline agrarisch & 91,0 & 73,3 \\
\hline technisch & 90,0 & 63,0 \\
\hline transport, communicatie & 86,0 & 62,5 \\
\hline (para)medisch & 96,3 & 70,6 \\
\hline economisch-administratief, commercieel & 89,0 & 67,7 \\
\hline juridisch-bestuurlijk & 89,5 & 66,7 \\
\hline sociaal-cultureel & 88,9 & 75,6 \\
\hline verzorging & 93,2 & 63,6 \\
\hline orde \& veiligheid & 85,8 & -12 \\
\hline overig & 81,0 & 59,1 \\
\hline $\mathrm{HBO}$ & 92,2 & 76,9 \\
\hline onderwijzend & 90,4 & 73,5 \\
\hline technisch & 92,9 & -12 \\
\hline (para)medisch & 92,6 & 79,8 \\
\hline economisch-administratief, commercieel & 93,1 & 78,8 \\
\hline sociaal-cultureel & 94,0 & 82,9 \\
\hline overig & 91,7 & 74,5 \\
\hline wo & 94,4 & 85,9 \\
\hline wiskunde en natuurwetenschappen & 94,9 & 75,0 \\
\hline technisch & 93,5 & -12 \\
\hline (para)medisch & 91,1 & 75,0 \\
\hline economisch-administratief, commercieel & 95,8 & -13 \\
\hline sociaal-cultureel & 98,0 & 90,0 \\
\hline overig & 94,8 & 87,9 \\
\hline ONBEKENDE OPLEIDINGSKWALIFICATIE & 88,5 & 75,0 \\
\hline Totaal & 81,3 & 54,1 \\
\hline
\end{tabular}

Bron: CBS, 1991

11. Het gaat hier om de standaard participatiegraad, dat wil zeggen: de beroepsbevolking als percentage van de totale bevolking, beiden voorzover tussen de 15 en 64 jaar.

12. Aangezien de beroepsbevolking minder dan 500 vrouwen met een dergelijke onderwijskwalificatie bevat kan de (overigens lage) participatiegraad voor deze groep niet worden berekend.

13. Bij deze onderwijskwalificatie is niet alleen het aantal vrouwen in de beroepsbevolking, maar tevens hun aantal in de totale bevolking te laag om de participatiegraad te berekenen. 
In het voorgaande is de arbeidsmarktparticipatie van mannen en vrouwen besproken. We hebben daarbij afzonderlijk aandacht geschonken aan het effect van leeftijd, burgerlijke staat, het hebben van jonge kinderen en het genoten onderwijs op de deelname van met name vrouwen aan het arbeidsproces. Deze paragraaf over arbeidsmarktparticipatie wordt daarom besloten met de kanttekening, dat men zich dient te realiseren dat tussen bovengenoemde factoren echter ook een grote mate van samenhang bestaat.

\subsection{Deeltijdarbeid}

Ondanks de forse stijging van de participatiegraad onder (gehuwde) vrouwen sinds het begin van de jaren zestig, is het werkgelegenheidsaandeel van vrouwen in deze periode slechts licht gestegen. Het werkgelegenheidsaandeel wordt namelijk berekend op basis van arbeidsjaren ${ }^{14}$ in plaats van personen, zoals bij de bepaling van de deelnemingsgraad gebeurt. Bovendien behoren werklozen ook tot de beroepsbevolking, waarop de participatiegraad is gebaseerd, terwijl werklozen niet bij de berekening van het werkgelegenheidsaandeel worden betrokken. Doordat vrouwen, vaker dan mannen, in deeltijd werken en de geregistreerde werkloosheid onder vrouwen relatief hoger is dan die onder mannen, is het aandeel van vrouwen in het betaalde werk, het zogenaamde werkgelegenheidsaandeel, derhalve kleiner dan hun aandeel in de beroepsbevolking. Zo was het aandeel van vrouwen in de beroepsbevolking in $198334 \%$, maar hun werkgelegenheidsaandeel slechts $26 \%$ (Bruyn-Hundt, 1988, blz. 35). In de periode 1977-1985 is het werkgelegenheidsvolume van vrouwen met $16 \%$ gestegen, terwijl het aantal werkzame vrouwen in dezelfde periode is toegenomen met ruim 29\% (Huijgen, 1989, blz. 56). Brouns en Schokker (1990, blz. 27) merken dan ook op dat "De herverdeling van de betaalde arbeid voor een belangrijk deel een herverdeling onder vrouwen blijkt te zijn geweest.".

Tabel 7. Wekelijkse arbeidsduur van werkzame vrouwen in loondienst in 1979, 1985 (beiden op basis van $\mathrm{AKT}$ ), 1987 en 1990 (beiden op basis van EBB) in procenten

$$
\begin{aligned}
& \text { Wekelijkse Arbeidsduur Vrouwen (in \%) } \\
& \geq 35 \text { uur } \\
& <35 \text { uur }
\end{aligned}
$$

$\begin{array}{lll}1979 & 55 & 45 \\ 1985 & 45 & 55 \\ 1987 & 42 & 58 \\ 1990 & 40 & 60\end{array}$

Bron: CBS/ROA

Dit beeld wordt bevestigd wanneer de wekelijkse arbeidsduur van in loondienst werkende

14. Arbeidsjaren hebben betrekking op het aantal personen, gecorrigeerd voor het aantal uren waarvoor zij een arbeidsovereenkomst hebben. In dit verband wordt ook vaak gesproken over de zogenaamde 'P/A-ratio'; i.c. het aantal personen per arbeidsjaar. Voor mannen was de P/A-ratio in de periode 1979-1985 gemiddeld 1,24; voor vrouwen 1,94 (BruynHundt, 1988, blz. 34). 
vrouwen in 1979 wordt vergeleken met die in 1985, 1987 en 1990. Zoals uit bovenstaande tabel blijkt, werkten in $197955 \%$ van deze vrouwen in een full-time baan, terwijl in 1985 nog maar $45 \%$ een volledige arbeidsweek had. Op zich zou de afname van full-time werkende vrouwen tussen 1985 en 1987 toegeschreven kunnen worden aan het feit, dat kleine banen in de EBB in vergelijking met de AKT worden overschat. In 1990 blijkt het percentage in deeltijd werkende vrouwen ook ten opzichte van 1987 te zijn toegenomen, zodat de toename van deeltijdarbeid na 1985 niet alleen een gevolg lijkt te zijn van een gewijzigde vraagstelling in de EBB.

Dat deeltijdwerk (nog steeds) vrouwenwerk is (Bruyn-Hundt, 1988, blz. 30) blijkt wel uit de gegevens uit de Enquête Beroepsbevolking (CBS, 1991). Van de vrouwen werkt in $199060 \%$ in deeltijd, terwijl van de mannen nog geen $15 \%$ in deeltijd werkzaam is. Mannen blijken, voor zover zij in deeltijd werken, verhoudingsgewijs zeer kleine deeltijdbanen te hebben. Bij de mannen gaat het hier met name om scholieren en studenten die naast hun studie een bijbaantje hebben. Zoals gezegd worden deze baantjes in de EBB, anders dan in de AKT, wel gemeten.

Dat het hier met name bijbaantjes van scholieren en studenten betreft blijkt enerzijds uit de grote verschuiving in kleine deeltijdbanen tussen 1985 (AKT) en 1990 (EBB) die zich voornamelijk heeft voorgedaan bij de werkende mannen. Terwijl bij mannen het percentage dat minder dan 15 uur per week in loondienst werkt tussen 1985 en 1990 is gestegen van 2 naar 7 procent, is dit percentage bij de vrouwen slechts toegenomen van 19 naar 23 procent. Anderzijds geven mannen dit ook vaak zelf op als reden voor het hebben van een deeltijdbaan; namelijk in $45 \%$ van de gevallen dat zij in deeltijd werken (zie tabel 8). Daarentegen is de zorgplicht voor het huishouden en/of het gezin voor bijna de helft van de vrouwen de reden, dat zij in deeltijd werken. Van de weinige in deeltijd werkende mannen geeft daarentegen slechts $3 \%$ aan dat de taken in het huishouden en/of gezin de reden zijn voor het hebben van een deeltijdbaan. Verhoudingsgewijs is bij mannen (een minder goede) gezondheid voor het werken in deeltijd belangrijk. Het feit dat men alleen een deeltijdbaan kon krijgen blijkt bij beide sexen in ongeveer gelijke mate een rol te spelen.

Tabel 8. Reden deeltijdbaan naar sexe van personen in loondienst van 15-64 jaar in 1990 in procenten

\begin{tabular}{|c|c|}
\hline Reden deeltijdbaan & Mannen \\
\hline
\end{tabular}

Reden Deeltijdbaan

Huishouding en/of gezin

Gezondheid

Volgt nog een opleiding

Kon alleen deeltijdbaan krijgen

Andere reden

$\begin{array}{rr}3 & 49 \\ 11 & 2 \\ 45 & 12 \\ 25 & 26 \\ 15 & 11\end{array}$

Bron: CBS/ROA

Deeltijders, dat wil hier zeggen, werkenden met een werkweek van minder dan 35 uur, blijken 
met name werkzaam te zijn in de dienstensector in het algemeen en bij de overheid en semioverheidsbedrijven in het bijzonder. Circa $50 \%$ van alle deeltijders werkte in 1989 namelijk in de CBS-bedrijfssector 'overige dienstverlening' loverheid, gezondheidszorg en maatschappelijke dienstverlening, schoonmaakwerk e.d.) en $20 \%$ van hen bleek werkzaam in de handel, de horeca en de reparatiesector. Hierbij gaat het met name om vrouwen, terwijl mannelijke deeltijders naar verhouding meer in de industrie voorkomen (zie ook Bruyn-Hundt, 1988, blz. 31).

Wanneer wordt bezien in welke beroepsklassen meer dan $50 \%$ van de werkenden een deeltijdbaan heeft (in casu een werkweek van minder dan 30 uur), dan blijkt het te gaan om de volgende CBS-beroepsklassen: verzorgend personeel in de gezins-, bejaarden- en kinderverzorging, huishoudelijk en schoonmaakpersoneel, markt- en straatverkopers, docenten en onderwijzers, evenals enkele vrije en kunstberoepen, zoals auteurs en uitvoerende kunstenaars (zie ook Bruyn-Hundt, 1988, blz. 31).

Binnen de relatie tussen deeltijdarbeid, sexe en bedrijfs-, c.q. beroepssector is sexe in eerste instantie de verklarende variabele. De verschillen die er tussen bedrijfssectoren, dan wel beroepssectoren bestaan voor wat betreft de mate waarin de werkenden in deeltijd werkzaam zijn, zijn namelijk in de eerste plaats een afgeleide van de aandelen van vrouwen in de betreffende bedrijfs- en beroepssectoren. De gegevens in onderstaande tabellen over deeltijdwerk naar sexe en bedrijfs- en beroepssector tonen dit aan.

Tabel 9. Werkzame personen naar sexe, CBS-beroepssector en percentage dat in deeltijd werkzaam is (< 35 uur per week) in 1989

Beroepssector

\% in deeltijd werkzaam
Vrouw

0-1 Wetenschappelijke e.a. vakspecialisten, kunstenaars

2 Beleidvoerende en hogere leidinggevende functies

Administratieve functies

Commerciële functies

Dienstverlenende functies

Agrarische beroepen

7-9 Ambachts-, industrie- en transportberoepen 
Tabel 10. Werkzame personen naar sexe, CBS-bedrijfssector en percentage dat in deeltijd werkzaam is (< 35 uur per week) in 1989

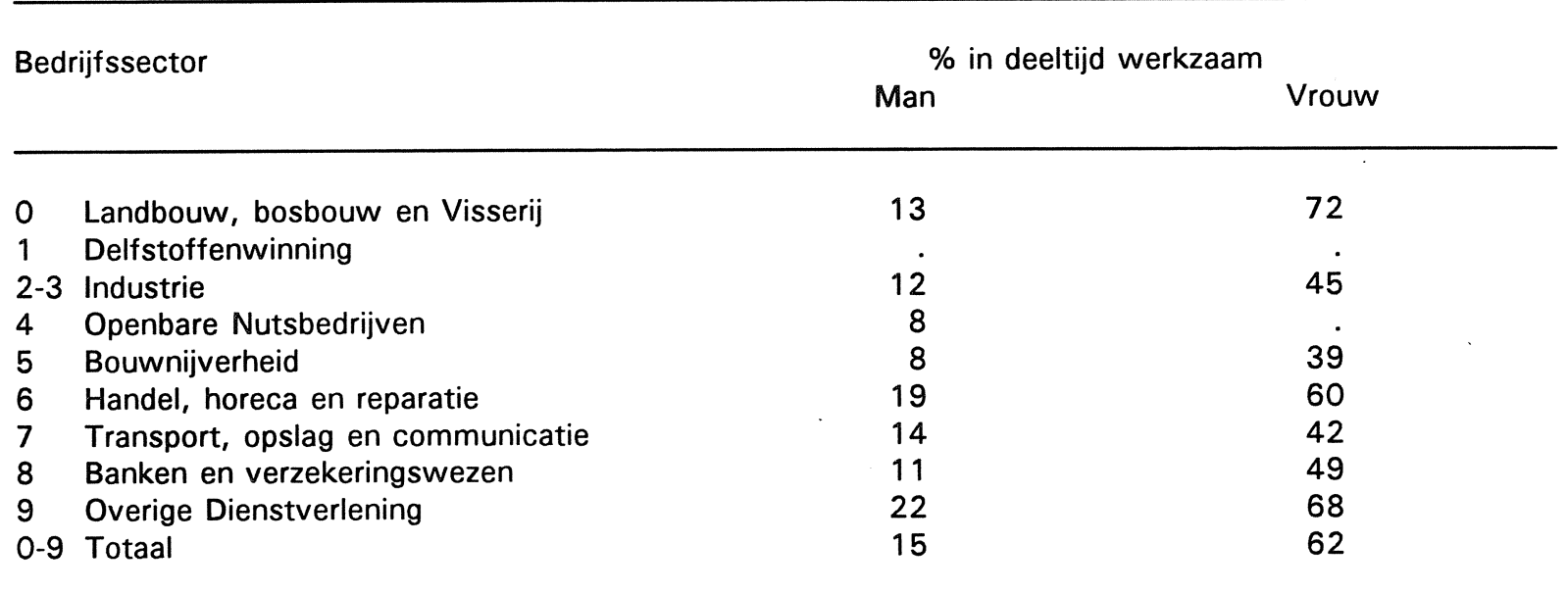

Bron: Ministerie van Sociale Zaken en Werkgelegenheid 1990

\subsection{Werkloosheid}

De verschillen tussen beide sexen met betrekking tot hun deelname aan het arbeidsproces worden niet alleen bepaald door hun verschillen in participatiegraad en deeltijdarbeid, maar evenzeer door discrepanties tussen mannen en vrouwen wat betreft het verwerven, dan wel het verliezen van betaald werk. Zo blijkt de geregistreerde werkloosheid ${ }^{15}$ onder vrouwen verhoudingsgewijs hoger te zijn dan onder mannen (zie tabel 11 ).

Hierbij is dan nog geen eens rekening gehouden met de 'verborgen' werkloosheid, die onder vrouwen groter is dan onder mannen. Door de wijze waarop het begrip geregistreerde werkloosheid in Nederland is geoperationaliseerd, wordt de werkloosheid onder met name vrouwen onderschat. Personen (van 15 tot 65 jaar) die zich namelijk niet (omdat bijvoorbeeld hun partner al een inkomen of uitkering heeft) of slechts voor een baan voor minder van minder dan 20 uur per week laten inschrijven of niet in staat zijn om binnen twee weken een baan te aanvaarden, worden namelijk niet tot de geregistreerde werklozen gerekend.

Hoewel de in 1985 ingezette daling van de werkloosheid zich onverminderd voortzet, blijkt deze daling zich niet gelijk over beide sexen te verdelen. Terwijl tussen de twee driemaandelijkse werkloosheidsgemiddelden van september-november 1988 en april-juni 1990 het aantal werkloze mannen met bijna een kwart is gedaald, nam de werkloosheid onder vrouwen in die periode slechts met $13 \%$ af. Dit verschil tussen mannen en vrouwen heeft met name betrekking op de kortdurige werkloosheid van minder dan een jaar. In de bovengenoemde periode 19881990 is de kortdurige werkloosheid onder mannen namelijk driemaal zo snel gedaald als die

15. Tot de geregistreerde werklozen worden gerekend: de bij een arbeidsbureau ingeschreven personen in de leeftijd van 16 tot en met 64 jaar die geen werkkring hebben en die 20 uur per week in loondienst willen werken en die daarvoor (binnen 2 weken) beschikbaar zijn. 
onder vrouwen, terwijl bij de langdurige werkloosheid het percentage onder de vrouwen meer is afgenomen (Ministerie van Sociale Zaken en Werkgelegenheid, 1990, blz. 8).

Tabel 11. Geregistreerde werklozen absoluut $(x 1000)$ en in $\%$ van de afhankelijke beroepsbevolking ${ }^{16}$ 1975-1987

\begin{tabular}{lrrrrr}
\hline & 1975 & 1980 & 1985 & 1986 & 1987 \\
& & & & & \\
& 153,0 & 159,9 & 498,0 & 453,5 & 428,7 \\
werkloze mannen & 5,0 & 5,1 & 14,8 & 13,4 & 12,6 \\
$\begin{array}{l}\text { in \% v/d afhankelijke beroepsbevolking } \\
\text { werkloze vrouwen }\end{array}$ & 42,3 & 88,0 & 263,0 & 257,2 & 256,8 \\
in \% v/d afhankelijke beroepsbevolking & 5,0 & 8,8 & 18,5 & 17,7 & 17,4 \\
\hline
\end{tabular}

Bron: CBS

16. Het gaat hier om de afhankelijke beroepsbevolking in strikte zin; dat zijn de werkenden en werkzoekenden die twintig uur of meer per week in loondienst (willen) werken (zie ook Bruyn-Hundt, 1988, blz.28). 


\section{GESLACHTSSPECIFIEKE SEGREGATIE NAAR OPLEIDING EN BEROEP}

\subsection{Inleiding}

Wat precies mannen- en vrouwenwerk is, is geen vast gegeven. Definities van vrouwen- en mannenberoepen verschillen naar tijd en plaats. Het enige permanente in de geschiedenis is, dat steeds opnieuw zo'n onderscheid wordt gemaakt (De Bruijn, 1986). Deze scheiding tussen mannen- en vrouwenwerk, in casu geslachtsspecifieke segregatie, is dan ook niet specifiek voor Nederland en niet specifiek voor deze tijd (Tijdens in Tijdschrift voor Arbeidsvraagstukken, 1990/4, blz. 13). Bovendien gaat deze segregatie gepaard met verschillen in (materiële) waardering voor het verrichte werk; mannenwerk kent in de regel een hogere maatschappelijke waardering dan werk dat door vrouwen wordt verricht (Van Doorne-Huiskes, 1987).

Voor een belangrijk deel blijken mannen en vrouwen dus op verschillende deelmarkten (segmenten) te werkzaam te zijn. Mok (geciteerd in Bruyn-Hundt, 1988, blz. 125) omschrijft arbeidsmarktsegmentatie als: 'Het historisch proces, waarbij onder invloed van politieke, economische en technologische factoren de arbeidsmarkt verdeeld raakt in strikt van elkaar gescheiden submarkten of segmenten, elk met specifieke kenmerken en gedragsregels' ${ }^{17}$. Als bijvoorbeeld segregatie naar bedrijfssector wordt bekeken, dan blijken, zoals gezegd, de handel en horeca, het bank- en verzekeringswezen evenals de zakelijke en de overige dienstverlening typische 'vrouwensectoren' te zijn. Daarentegen vormen de landbouw en visserij, de industrie, de bouw, alsmede het transportwezen typische 'mannensectoren' (Tijdens, 1989).

In de regel wordt bij (geslachtsspecifieke) segregatie alleen de (horizontale) ${ }^{18}$ beroepssegregatie in beschouwing genomen. Hierdoor blijft een belangrijke component van de segregatie buiten beschouwing. Er bestaat immers een sterke relatie tussen opleiding en beroep (Beleidsplan Emancipatie, 1984/'85, blz. 10), zodat de totale beroepssegregatie kan worden gesplitst in twee componenten. Allereerst vindt er tijdens het onderwijstraject een voorsortering naar kwalificatie plaats. Daarna volgt een tweede sortering tijdens het arbeidsleven met betrekking tot de beroepskeuze en loopbaantrajecten. Wil men de beroepssegregatie tegengaan, dan zal dus enerzijds moeten worden bevorderd, dat mannen en vrouwen met dezelfde onderwijskwalificaties in dezelfde beroepen (kunnen) terechtkomen en zullen anderzijds de verschillen tussen mannen en vrouwen wat betreft de voorsortering in het onderwijs moeten worden gereduceerd (Groot in Tijdschrift voor Arbeidsvraagstukken, blz. 4-12). Dat dit niet een eenvoudige opgave zal zijn komt door het hardnekkige en complexe karakter van de segregatie;

17. Van de Poll (Tijdschrift voor Arbeidsvraagstukken, 1990/4, blz. 26-37) toont aan, dat in Nederland niet echt sprake is van een zogenaamde 'dubbele arbeidsmarkt', maar wel van segmenterings-tendensen.

18. Naast horizontale beroepssegregatie, waarbij het gaat om een scheiding tussen mannenen vrouwen-beroepen naar aard, dan wel richting van het beroep, onderscheidt men ook verticale segregatie, waarbij de verschillen tussen functieniveau's (c.q. statusverschillen) in het geding zijn. 
er bestaat namelijk een samenhang tussen segregatie, kwaliteit van de arbeid, taakinhoudelijke aspecten en status van het beroep (Brouns en Schokker, 1990, blz. 190).

In deze paragraaf zullen, juist vanwege de relatie tussen opleiding en beroep, zowel de opleidings-, als beroepssegregatie aan bod komen. Voor beide vormen van segregatie zullen de volgende twee segregatie-indices worden gebruikt ${ }^{19}$.

Ten eerste wordt de ongelijkheidsmaatstaf van Duncan (s) gebruikt, waarbij een waarde van 0 wil zeggen dat de mannelijke en de vrouwelijke beroepsbevolking gelijk over de beroepen, c.q. opleidingen zijn verdeeld, zodat de beroeps-, dan wel opleidingsstructuur van de mannelijke en vrouwelijke beroepsbevolking identiek is. Een waarde van 1 geeft daarentegen aan dat de segregatie compleet is, dat wil zeggen, dat er geen beroepen, c.q. opleidingen zijn, waar zowel mannen als vrouwen zijn vertegenwoordigd. Deze segregatie-index (s) geeft antwoord op de vraag hoe groot de som bedraagt van het percentage van de mannelijke beroepsbevolking en het percentage van de vrouwelijke beroepsbevolking, dat van beroep, c.q. opleiding dient te veranderen, opdat de procentuele verdeling van het aantal beroepsbeoefenaren over de onderscheiden beroepen, c.q. opleidingen voor mannen en vrouwen dezelfde is.

In de tweede plaats wordt een gecorrigeerde segregatie-index (S) gehanteerd, welke het percentage van de totale beroepsbevolking weergeeft, dat van beroep, c.q. opleiding dient te veranderen ten einde alle segregatie te doen verdwijnen onder de restrictie dat de verdeling van de totale beroepsbevolking over de onderscheiden beroepen, c.q. opleidingen ongewijzigd blijft.

Voor een juiste interpretatie van de indices $S$ en $S$ is het voorts van belang om te weten dat, ontwikkelingen in de index $S$ het gevolg kunnen zijn van enerzijds ontwikkelingen in de segregatie-index $s$ en anderzijds ontwikkelingen in het aandeel van vrouwen in de beroepsbevolking ${ }^{20}$. De index $s$ wordt, zoals gezegd, aan de ene kant beïnvloed door een gewijzigde verdeling van de totale beroepsbevolking over de beroepen en opleidingskwalificaties; aan de andere kant door gewijzigde aantalsverhoudingen tussen mannen en vrouwen binnen de beroepen en opleidingskwalificaties (zie ook Van Mourik en Siegers, 1988, blz. 734).

De segregatie-indices zijn berekend op basis van de arbeidskrachtentellingen uit 1979 en 1985 . Zowel de beroeps-, als de opleidingssegregatie is bovendien verbijzonderd naar respectievelijk functie- en opleidingsniveau.

19. Voor de formules van $S$ en $S$ wordt verwezen naar Groot (in Tijdschrift voor Arbeidsvraagstukken, 1990/4, blz. 7) en Siegers (in Economisch Statistische Berichten, 28-2-1979, blz. 208-213).

20. Siegers (1979, blz. 210) toont aan, dat de index S stijgt, indien het percentage vrouwen in de beroepsbevolking toeneemt. 


\subsection{Onderwijssegregatie}

Voordat de onderwijssegregatie-indices worden besproken, worden eerst nog enkele algemene onderwijsontwikkelingen geschetst. Onderstaande grafieken laten voor beide sexen afzonderlijk de cumulatieve procentuele uitstroom van gediplomeerden uit verschillende onderwijsniveaus van het voltijdsonderwijs zien. De studiejaren 1978/'79 tot en met 1987/'88 betreffen historische cijfers op basis van de onderwijsmatrices van het CBS, terwijl de periode 1988/' 89 tot en met 1993/'94 geprognosticeerde cijfers omvat, die zijn ontleend aan de tijdreeksen uit de SKILL onderwijsprognoses (1990) van het Ministerie van Onderwijs en Wetenschappen.

De grafieken overziend blijkt het cumulatieve aandeel van het AVO en LBO samen, evenals de ontwikkeling daarin, voor zowel mannen als vrouwen hetzelfde (zie figuur 2). Aan het begin van de jaren tachtig bestond bij beide sexen $60 \%$ van de gediplomeerde uitstroom uit LBO-ers en mensen van het AVO. In 1994 zal bij zowel mannen als vrouwen circa $30 \%$ van deze uitstroom uit gediplomeerden van het LBO en AVO bestaan. Deze relatieve daling van de uitstroom uit het LBO en AVO is het sterkste bij het LBO, gevolgd door het MAVO (lagere trap AVO). Deze daling is overigens eind jaren tachtig minder scherp geweest, dan aan het begin van het vorige decennium. Binnen de uitstroom uit het AVO en LBO bestaat echter een belangrijk verschil tussen beide sexen. Vrouwen stromen namelijk twee maal zo vaak uit het algemeen voortgezet onderwijs dan mannen. Dit was niet alleen zo in het recente verleden, maar dit verwacht men ook voor de nabije toekomst. Daarentegen stromen mannen vaker uit het lager beroepsonderwijs dan vrouwen.

Begin jaren tachtig was het relatieve aandeel van de uitstroom uit het MBO bij vrouwen aanzienlijk hoger dan bij mannen (circa 25 versus 15 procent). Deze discrepantie tussen mannen en vrouwen zal begin jaren negentig echter voor een belangrijk deel verdwenen zijn. Omgekeerd halen vrouwen in snel tempo hun achterstand in bij de uitstroom uit het wetenschappelijk onderwijs. Rond 1980 immers bestond de uitstroom van gediplomeerde vrouwen uit het voltijdsonderwijs slechts voor $5 \%$ uit WO-ers, terwijl in het studiejaar $1993 /$ ' 94 circa $15 \%$ van deze uitstroom uit WO-ers zal bestaan. Bij de mannen zal dit begin jaren negentig eveneens zo'n $15 \%$ bedragen.

Bij de uitstroom uit het WO heeft zich tussen 1986 en 1988 een trendbreuk voorgedaan. De uitstroom heeft zich in deze periode namelijk bijna verdubbeld! Dit is het gevolg van het feit dat in deze periode zowel de zogenaamde Oude als Nieuwe Stijlers tegelijkertijd konden afstuderen. $\mathrm{Na} 1989$ is deze uitstroom dan ook weer (relatief) afgenomen. 
Figuur 2. Cumulatieve uitstroom van gediplomeerden uit verschillende opleidingsniveaus van het voltijdsonderwijs naar sexe tussen de studiejaren 1978/'79 en 1993/'94 in procenten

Uitstroom gediplomeer de mannen

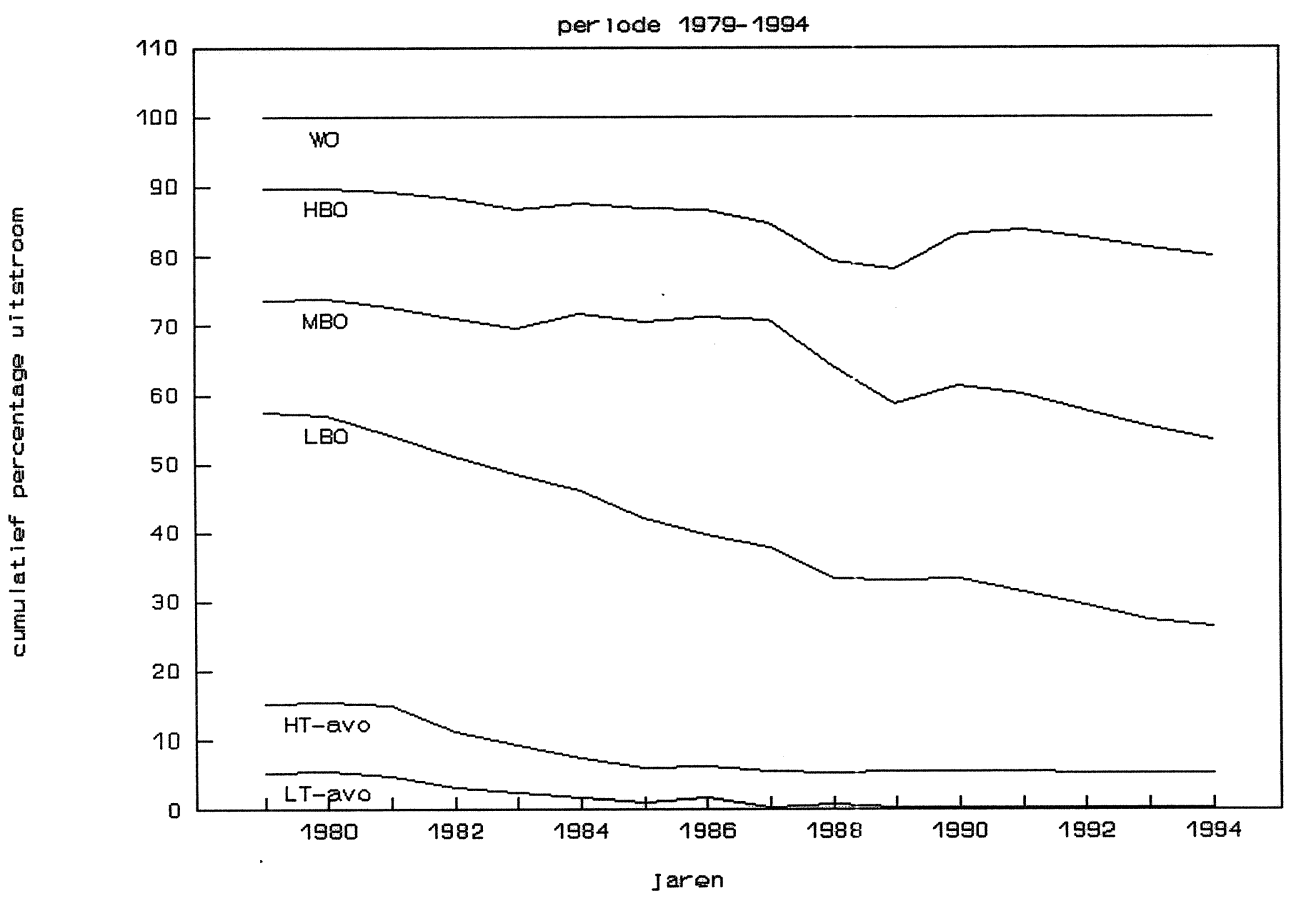

Uitstroom gediplomeerde vrouwen

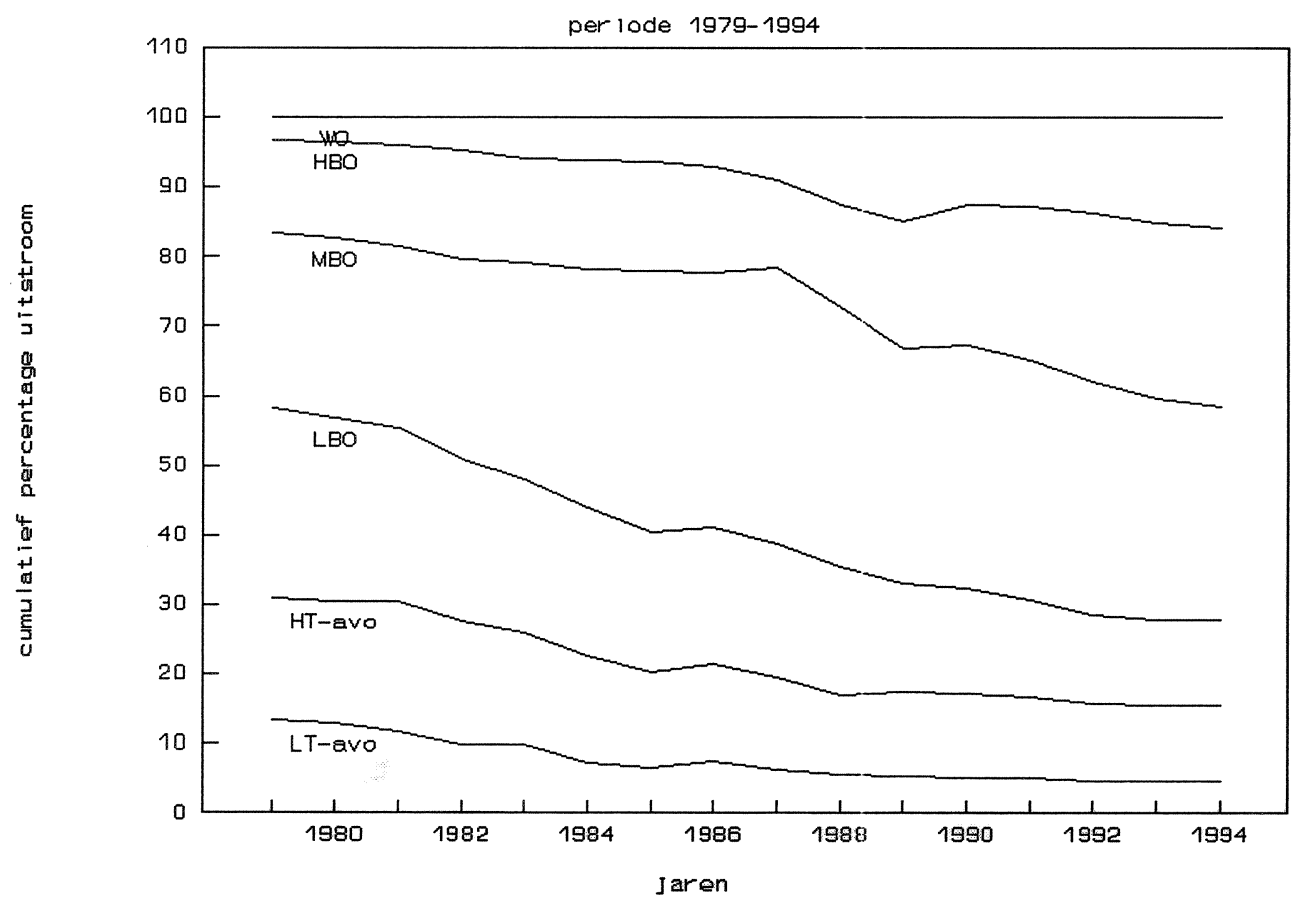

Bron: CBS/Ministerie van Onderwijs en Wetenschappen 
Tabel 12. Aandeel van gediplomeerden dat het voltijdsonderwijs verlaat naar sexe en onderwijsniveau in 1979-1987 in procenten

\begin{tabular}{|c|c|c|c|c|}
\hline \multirow[b]{2}{*}{ Onderwijsniveau } & \multicolumn{2}{|c|}{ Mannen } & \multicolumn{2}{|c|}{ Vrouwen } \\
\hline & 1979 & 1987 & 1979 & 1987 \\
\hline Lagere trap AVO (MAVO) & 13 & 1 & 27 & 13 \\
\hline Hogere trap AVO (HAVO/VWO) & 22 & 12 & 41 & 27 \\
\hline LBO & 61 & 49 & 54 & 42 \\
\hline MBO & 84 & 79 & 93 & 88 \\
\hline HBO & 93 & 94 & 95 & 94 \\
\hline wo & 100 & 100 & 100 & 100 \\
\hline
\end{tabular}

Bron: CBS/ROA

Voor een goed overzicht van de discrepanties tussen mannen en vrouwen in het volgen van onderwijs in het algemeen en de aansluiting naar de arbeidsmarkt in het bijzonder, is het van belang om ook hun verschillen in uitstroom uit het voltijdsonderwijs naar de arbeidsmarkt te analyseren. Het gaat hier om het percentage van de gediplomeerde mannen en vrouwen dat het voltijdse onderwijs verlaat om, al dan niet in combinatie met een deeltijdopleiding in bijvoorbeeld het leerlingwezen een baan te gaan zoeken ${ }^{21}$.

Uit bovenstaande tabel blijkt, dat in toenemende mate de uitstroom naar de arbeidsmarkt met het stijgen van het laatst gevolgde onderwijsniveau groter wordt. Degenen die hun diploma in het beroepsonderwijs hebben behaald, stromen overigens in grotere mate door naar de arbeidsmarkt, dan degenen die een algemeen voortgezette opleiding hebben voltooid. De relatie tussen onderwijs en arbeidsmarkt blijkt bij de beroepsopleidingen, ook op het laagste niveau, dus sterker dan bij het algemeen voortgezet onderwijs.

Op de lagere en middelbare onderwijsniveaus leren vrouwen over het algemeen minder lang door dan hun mannelijke studiegenoten (met uitzondering van het LBO; mannen verlaten na het behalen van het LBO-diploma vaker het voltijdsonderwijs dan vrouwen). Het verschil tussen mannen en vrouwen in uitstroompercentage is in de periode 1979-1987 ongeveer gelijk gebleven. Bij de uitstroom uit het MAVO is dit verschil zelfs toegenomen. Terwijl van de gediplomeerde mannen van het MAVO in 1987 vrijwel iedereen (99\%) verder doorleert in het voltijdsonderwijs, blijkt van deze vrouwen nog altijd $13 \%$ de schoolloopbaan in het voltijdsonderwijs na het behalen van het MAVO-diploma te beëindigen.

In de jaren tachtig hebben vrouwen (meisjes) hun onderwijsachterstand ten opzichte van mannen (jongens) wat betreft het hoogst behaalde onderwijsniveau, dan wel het aantal jaren

21. Het is in principe ook mogelijk, dat men het onderwijs verlaat om de militaire dienstplicht te vervullen of om de eigen huishouding te verzorgen. Het vervullen van de dienstplicht is echter maar een tijdelijke zaak en ook (laag opgeleide) vrouwen blijken meestal eerst een paar jaar te gaan werken alvorens de arbeidsmarkt voor het huishouden in te ruilen. 
dat onderwijs is gevolgd, blijkbaar voor een belangrijk deel ingehaald (zie ook Brouns en Schokker, 1990). Hoewel de scholingsgraad van vrouwen sinds 1980 sterk is gestegen en in de nabije toekomst bovendien verder zal toenemen, is de opleidingskeuze, evenals het vakkenpakket naar richting nog steeds 'traditioneel'; vrouwen worden met name opgeleid voor functies in de verzorgende, representatieve en assisterende sfeer (Beleidsplan Emancipatie 1984/'85, blz. 10). De segregatie tussen mannen en vrouwen wat betreft hun onderwijskwalificatie heeft dus met name betrekking op de richting van het door hen gevolgde onderwijs. Dit blijkt ook uit de onderwijssegregatie-indices, waarbij de opleidingen respectievelijk naar niveau ${ }^{22}$ en richting ${ }^{23}$ zijn onderscheiden.

Zoals onderstaande tabel aangeeft, zou in 1985 maar liefst $19 \%$ van de actieve beroepsbevolking bij een gelijkblijvende opleidingsstructuur van opleidingsrichting hebben moeten veranderen om de onderwijssegregatie ongedaan te maken, terwijl dit percentage met betrekking tot de segregatie naar opleidingsniveau slechts $2 \%$ bedraagt. De sterke segregatie naar richting duidt derhalve op een tamelijk sterke voorsortering naar opleidingsrichting (Groot, Tijdschrift voor Arbeidsvraagstukken, 1990/4, blz. 9).

Tabel 13. Onderwijssegregatie-indices (OS) in 1985 in procenten

S S

$\begin{array}{lrr}\text { OS bij } 4 \text { niveaus } & 4,6 & 2,1 \\ \text { OS bij } 5 \text { richtingen } & 41,5 & 18,7\end{array}$

Bron: Groot, 1990, blz. 9

Voor de 15 belangrijkste opleidingscategorieën ${ }^{24}$ staat in tabel 14 het percentage werkzame vrouwen aangegeven. Aangezien gemiddeld over alle onderscheiden opleidingstypen $34 \%$ van de actieve beroepsbevolking een vrouw betreft, is er sprake van over- of ondervertegenwoordiging naar gelang het aandeel van vrouwen hierin groter of kleiner is dan $34 \%$. Vrouwen met een verzorgende, economisch \& administratieve, pedagogische, alsmede algemene opleidingskwalificatie blijken (al dan niet sterk) te zijn oververtegenwoordigd. Daarentegen zijn mannen juist met een technische en agrarische kwalificatie zwaar

22. Het onderwijs is in vier niveaus onderverdeeld: basisonderwijs (SOI 1 en 2), lager (beroeps)onderwijs (SOI 3), middelbaar (beroeps)onderwijs (SOI 4) en hoger onderwijs (SOI 5 en 6).

23. Het onderwijs is in vijf richtingen onderverdeeld: algemeen, pedagogisch, technisch \& agrarisch, medisch \& verzorgend, evenals economisch \& juridisch.

24. Dit zijn de in 1990 door het ROA gehanteerde opleidingstypen die in 1985 een werkgelegenheidsaandeel van meer dan $1,5 \%$ hadden. Dat wil zeggen dat de werkenden met de betreffende opleiding als hoogst genoten opleidingskwalificatie tenminste $1,5 \%$ in de totale werkgelegenheid vormde. 
oververtegenwoordigd in de actieve beroepsbevolking.

Tabel 14. Over- of ondervertegenwoordiging van mannen en vrouwen naar opleiding in de actieve beroepsbevolking in 1985

\begin{tabular}{lr} 
Opleidingstype & \% Vrouwen \\
\hline & 31 \\
Basisonderwijs & 49 \\
MAVO, Onderbouw HAVO/VWO & 4 \\
LBO Agrarisch & 5 \\
LBO Technisch & 60 \\
LBO Economisch \& Administratief & 89 \\
LBO Sociale Verzorging \& Horeca & 43 \\
Bovenbouw HAVO/VWO & 6 \\
MBO Agrarisch & 3 \\
MBO Technisch \& Laboratorium & 85 \\
MBO Verpleging & 36 \\
MBO Economisch \& Administratief & 92 \\
MBO Sociale Verzorging & 50 \\
HBO Onderwijs & 1 \\
HBO Technisch & 41 \\
HBO Economisch \& Administratief & 34 \\
Totaal alle opleidingstypen &
\end{tabular}

Bron: $\mathrm{CBS} / \mathrm{ROA}$

Juist omdat de onderwijssegregatie naar niveau marginaal is in vergelijking met de segregatie tussen beide sexen naar opleidingsrichting, is op basis van de arbeidskrachtentellingen uit 1979 en 1985 voor beide jaren de richtingspecifieke onderwijssegregatie per opleidingsniveau nagegaan. Uit tabel 15 valt af te lezen, dat de segregatie tussen mannen en vrouwen naar opleidingsrichting met het toenemen van het opleidingsniveau afneemt. Binnen het LBO en het $M B O$ is de scheiding tussen typische mannen- en vrouwenopleidingen dus scherper, dan binnen het HBO en WO. Daarnaast blijkt de gecorrigeerde segregatie-index $S$ op alle opleidingsniveaus tussen de jaren 1979 en 1985 te zijn gestegen, terwijl de index s, met uitzondering van het laagste onderwijsniveau, licht is afgenomen. Voor de middelbare en hogere opleidingsniveaus is deze, op het eerste gezicht wellicht tegenstrijdige, ontwikkeling toe te schrijven aan het feit dat het aandeel van vrouwen in de beroepsbevolking in deze periode van $29 \%$ naar $34 \%$ is toegenomen. Op het laagste onderwijsniveau lijkt daarentegen de scheiding tussen mannen- en vrouwenopleidingen in die jaren te zijn toegenomen. 
Tabel 15. Richtingspecifieke onderwijssegregatie-indices s en S per opleidingsniveau in 1979 en 1985

\begin{tabular}{|c|c|c|c|c|}
\hline \multirow[b]{2}{*}{ Opleidingsniveau ${ }^{25}$} & \multicolumn{2}{|c|}{1979} & \multicolumn{2}{|c|}{1985} \\
\hline & $\mathbf{s}$ & S & $\mathbf{s}$ & S \\
\hline LBO, MAVO, onderbouw HAVO/VWO & 59.11 & 26.20 & 62.50 & 29.03 \\
\hline MBO, bovenbouw HAVO/VWO & 55.39 & 21.90 & 52.30 & 23.04 \\
\hline HBO & 38.27 & 16.42 & 37.49 & 17.59 \\
\hline Wo & 33.08 & 7.88 & 32.17 & 9.82 \\
\hline
\end{tabular}

Bron: CBS/ROA

In dit kader is het eveneens interessant om te kijken naar de verschillen tussen (werkzame) mannen en vrouwen wat betreft het deelnemen aan (bedrijfs)opleidingen. Immers, langs deze weg kunnen werknemers zich verder kwalificeren, hetgeen een positieve invloed kan hebben op het loopbaantraject. Zoals uit tabel 16 blijkt, nemen vrouwen minder vaak deel aan (bedrijfs)opleidingen dan mannen (Boot in Tijdschrift voor Politieke Ekonomie, 1989/3, blz. 99). Een onderzoek van Schippers (1986, in Bruyn-Hundt, 1988, blz. 131) naar bedrijfsopleidingen wijst uit, dat vrouwen in Nederland aanzienlijk minder kansen hebben op een bedrijfsopleiding, (mede) omdat in de bedrijven waar veel vrouwen werken minder vaak een interne opleiding aanwezig is dan in bedrijven waar veel mannen werkzaam zijn. Verschillen in kansen op een bedrijfsopleiding zijn dus mede het gevolg van sexesegregatie op de arbeidsmarkt, met andere woorden van het bestaan van typische 'mannen-' en vrouwenberoepen, alsmede 'mannen-' en 'vrouwensectoren'.

Tabel 16. Deelname aan cursussen en bedrijfscursussen naar sexe in 1988 in procenten

\begin{tabular}{lrr}
\hline & & 10,9 \\
Mannen & 16,3 & 9,7 \\
Vrouwen & 14,0 & 10,4 \\
Totaal M + V & 15,1 & \\
\hline
\end{tabular}

Bron: Boot in TPE, 1989/3, blz. 99

25. De opleidingsniveaus corresponderen met de eerste digit van de Standaard Onderwijs Indeling (SOI) van het CBS.

26. Het gaat hier om het aandeel van de potentiële beroepsbevolking dat op het moment van de ondervraging een cursus volgt.

27. Het gaat hier om het aandeel van de werkenden dat gedurende het voorafgaande jaar een bedrijfscursus heeft gevolgd. In de survey was naar deelname in de laatste twee jaar gevraagd; dit getal is door twee gedeeld, hetgeen ongetwijfeld een onderschatting zal geven. 
Concluderend kan men stellen, dat de segregatie tussen (werkzame) mannen en vrouwen wat betreft de gevolgde opleidingsrichting, die overigens afneemt bij een toename van het opleidingsniveau, aanzienlijk is en in de periode $1979-1985$ niet is afgenomen. Dit wijst op een sterke en hardnekkige voorsortering naar opleidingsrichting. Bovendien blijken mannen vaker deel te nemen aan (bedrijfs)cursussen, hetgeen consequenties heeft voor enerzijds de onderwijssegregatie naar zowel opleidingsniveau, als -richting en anderzijds voor de loopbaanontwikkeling van beide sexen.

\subsection{Beroepssegregatie}

Op de arbeidsmarkt lopen er scherpe scheidslijnen tussen de arbeid van mannen en vrouwen. Beide sexen zijn geconcentreerd in een aantal functies, die niet alleen (horizontaal) naar aard verschillen, maar tevens (verticaal) naar niveau, dan wel status. Er bestaan op de arbeidsmarkt dus typische 'vrouwen-' en 'mannenberoepen'. Van Mourik en Siegers (1988, blz. 732) stellen dat: "Een beroep wordt aangemerkt als mannenberoep wanneer daarin hoofdzakelijk mannen werkzaam zijn en als vrouwenberoep wanneer daarin hoofdzakelijk vrouwen werkzaam zijn.". Onder hoofdzakelijk verstaan zij in dat artikel een percentage van zestig of hoger. Tijdens (1989) kiest daarentegen voor een definitie van 'mannen-' en vrouwenberoepen die is gerelateerd aan de participatiegraad van vrouwen ( $34 \%$ in 1985 ) plus of $\min 15 \%$. In hoofdstuk 5 zal een aantal arbeidsmarktkenmerken worden besproken van de tien vrouwenberoepen, die in 1985 het hoogste aandeel werkzame vrouwen bevatten.

Tabel 17. Geslachtsspecifieke beroepssegregatie-indices s en S naar functieniveau in 1979 en 1985

\begin{tabular}{|c|c|c|c|c|c|}
\hline \multirow{2}{*}{$\begin{array}{l}\text { functie- } \\
\text { niveau }^{28}\end{array}$} & \multirow{2}{*}{$\begin{array}{l}\text { aantal } \\
\text { beroepen }\end{array}$} & \multicolumn{2}{|c|}{1979} & \multicolumn{2}{|c|}{1985} \\
\hline & & $s$ & $S$ & $s$ & $\mathrm{~S}$ \\
\hline 1 & 31 & 49.06 & 18.60 & 60.97 & 28.48 \\
\hline 2 & 74 & 69.66 & 28.48 & 66.30 & 30.33 \\
\hline 3 & 42 & 66.35 & 30.68 & 62.40 & 30.62 \\
\hline 4 & 49 & 69.58 & 29.47 & 68.79 & 31.82 \\
\hline 5 & 58 & 69.99 & 25.59 & 63.54 & 25.88 \\
\hline 6 & 36 & 58.61 & 16.28 & 54.13 & 15.45 \\
\hline 7 & 24 & 35.31 & 11.62 & 30.29 & 11.82 \\
\hline Totaal $^{30}$ & 314 & 66.17 & 27.23 & 63.53 & 28.32 \\
\hline
\end{tabular}

Bron: CBS/ROA

28. Voor het bepalen van het functieniveau is gebruik gemaakt van de score die Huijgen op basis van de beroepenclassificatie van ARBVO toekent aan de CBS-beroepsgroepen.

29. Het gaat hier om het aantal CBS-beroepsgroepen, dat per functieniveau is onderscheiden. Het aantal waarnemingen (i.c. beroepsgroepen) heeft namelijk een positieve invloed op de segregatie-indices.

30. De reden dat de door ons berekende segregatie-indices $S$ en $S$, waarvoor de berekeningswijzen van Siegers (1979) zijn gehanteerd, desondanks licht afwijken van de indices die door Van Mourik en Siegers (1988) zijn berekend, zijn terug te voeren op zeer kleine verschillen in de gebruikte datasets. 
Analoog aan het bepalen van de onderwijssegregatie zijn ook voor het meten van de beroepssegregatie de segregatie-indices $S$ en $S$ berekende op basis van gegevens uit de arbeidskrachtentellingen van 1979 en 1985 over het aantal werkzame personen in de door het CBS onderscheiden beroepsgroepen ${ }^{31}$.

$\mathrm{Er}$ is per functieniveau nagegaan hoe de beroepssegregatie tussen beide sexen zich in de periode 1979-1985 heeft ontwikkeld. De geslachtsspecifieke beroepssegregatie lijkt zich sterker voor te doen in het middenkader, dan in de beroepsgroepen met het laagste, dan wel hoogste beroepsniveau. Hierbij moet wel rekening worden gehouden met het feit, dat het aantal beroepsgroepen, op grond waarvan de segregatie-indices zijn berekend, de hoogte van de indices positief beïnvloedt. Aan de verschillen tussen de onderscheiden functieniveaus voor wat betreft de hoogte van de segregatie-indices kunnen derhalve geen (harde) conclusies worden verbonden.

Het is daarom beter de verschillen tussen de functieniveaus met betrekking tot de ontwikkeling van de segregatie tussen 1979 en 1985 te analyseren. Met uitzondering van het laagste functieniveau blijkt in de beschouwde periode de segregatie-index $s$ op alle functieniveaus behoorlijk te zijn gedaald, terwijl tussen 1979 en 1985 de index $S$ licht is gestegen. Ook de beroepssegregatie, geaggregeerd over alle functieniveaus, komt met dit beeld overeen. De interpretatie van de resultaten van de sexespecifieke beroepssegregatie met betrekking tot de functieniveaus 2 tot en met 7 kan derhalve aansluiten bij hetgeen Van Mourik en Siegers (1988) eerder hebben opgemerkt over de beroepssegregatie tussen mannen en vrouwen in Nederland, waarbij zij overigens geen onderscheid naar functieniveau hebben gemaakt.

Op het laagste functieniveau heeft de beroepssegregatie tussen beide sexen zich in de periode 1979-1985 echter op andere wijze ontwikkeld. Terwijl op de andere functieniveaus de toenemende participatie, welke een positief effect heeft op de index $S$, gecompenseerd werd door een daling van de segregatie-index $s$, is op het laagste functieniveau deze laatste index $\mathbf{s}$ ook sterk toegenomen. Zoals Van Mourik en Siegers (1988) aangeven, zijn de ontwikkelingen in de index $s$ afhankelijk van wijzigingen in enerzijds de verdeling van de beroepsbevolking over de onderscheiden beroepsgroepen en anderzijds de verhouding tussen mannen en vrouwen binnen beroepen. Een reden voor de toename van de index $s$ zou gelegen kunnen zijn in het feit, dat in de afgelopen jaren enerzijds de toename van vrouwen juist in beroepen op het laagste functieniveau heeft plaatsgevonden, terwijl anderzijds mannen met name uit beroepen op het laagste functieniveau zijn vertrokken. Het laagste functieniveau lijkt dus meer en meer een 'vrouwensegment' te worden (zie ook Elfring en Kloosterman, 1989).

Over het algemeen echter blijkt, zoals gezegd, dat in de periode 1979-1985 de index $s$ is gedaald, terwijl de index $S$ is toegenomen. Uit een componentenanalyse van de ontwikkelingen in de index S, die van Mourik en Siegers (1988) destijds hebben uitgevoerd, blijkt dat het

31. Hierbij gaat het om het 3-cijferige niveau (3e digit) van de CBS-beroepenclassificatie, waarin het CBS 323 beroepsgroepen onderscheidt. 
positieve effect van de stijging van het aandeel van vrouwen in de beroepsbevolking het effect van de daling van de segregatie-index s overtreft. Beide factoren blijken, op grond van wederom een componentenanalyse door Van Mourik en Siegers (1988), te hebben geleid tot een daling van de segregatie-index s. Het effect van de gewijzigde beroepenstructuur blijkt daarbij overigens groter te zijn dan het effect van de gewijzigde aantalsverhoudingen van mannen en vrouwen binnen beroepen.

Van Mourik en Siegers (1988, blz. 735) concluderen dan ook dat "Verschuivingen in de beroepenstructuur er blijkbaar toe hebben geleid, dat het aandeel van de werkenden in vrouwenberoepen is toegenomen ten opzichte van het aandeel van de werkenden in mannenberoepen". Bovendien blijkt "de procentuele stijging van het aandeel van vrouwen in mannenberoepen kleiner dan de procentuele stijging van het aandeel van mannen in vrouwenberoepen" (Van Mourik en Siegers, 1988, blz. 735). Juist de wijze waarop de toenemende participatie van vrouwen en met name het vertrek van mannen uit de beroepsbevolking in de periode 1979-1985 tot stand is gekomen, heeft een aantal opmerkelijke gevolgen gehad voor de beroepenstructuur in het algemeen en de beroepssegregatie in het bijzonder.

Aan de ene kant blijkt nog steeds het overgrote deel van de groei van de vrouwelijke beroepsbevolking terecht te komen in beroepen waarin vrouwen zijn oververtegenwoordigd, alhoewel dit in afnemende mate gebeurt ${ }^{32}$. Aan de andere kant blijkt de daling van $4 \%$ van de mannelijke beroepsbevolking tussen 1979 en 1985 samengesteld te zijn uit een toename van $1 \%$ van de mannelijke beroepsbevolking die ging naar beroepen waarin vrouwen zijn oververtegenwoordigd en een daling van $5 \%$ ten gevolge van vertrek uit beroepen waarin mannen zijn oververtegenwoordigd. Van Mourik en Siegers (1988, blz. 735) merken dan ook op dat deze ontwikkelingen met betrekking tot de mannelijke beroepsbevolking weliswaar enerzijds bijdragen aan het verminderen van de beroepssegregatie, maar anderzijds een bedreiging vormen van de werkgelegenheidspositie van vrouwen. Pleidooien voor roldoorbreking en opheffing van de scheiding tussen traditionele 'mannen-' en vrouwenberoepen blijken derhalve nogal een eenzijdig effect te hebben. In toenemende mate worden mannen aangesteld in functies in bijvoorbeeld de verpleging en het maatschappelijke werk die tot voor kort vrijwel uitsluitend door vrouwen werden uitgeoefend. Het omgekeerde komt echter nauwelijks voor. Mannen nemen bovendien binnen die tot voor kort 'vrouwelijke' beroepen in toenemende mate de hogere functies voor hun rekening. Ook hiervan wordt het omgekeerde nauwelijks gesignaleerd (zie ook Beleidsplan Emancipatie 1984/'85, blz. 10; Van Mourik en Siegers, 1988, blz. 735). Het risico bestaat, dat een mogelijke afname van de horizontale beroepssegregatie tussen beide sexen, gepaard zal gaan met een toename van de verticale segregatie.

32. In de periode 1971-1979 ging $84 \%$ van de groei van de vrouwelijke beroepsbevolking naar beroepen waarin vrouwen waren oververtegenwoordigd en slechts $16 \%$ naar beroepen waarin mannen waren oververtegenwoordigd. In de periode 1979-1985 bedroegen deze percentages respectievelijk 76 en 24. 
Hierna worden in het kort enkele onderzoeken besproken welke ingaan op de verschillen tussen mannen en vrouwen met betrekking tot de verticale beroepsmobiliteit.

Het eerste onderzoek van de Loontechnische Dienst (1988) gaat over de positie van mannen en vrouwen in het arbeidsproces. In dit onderzoek heeft de Loontechnische Dienst onder andere het functieniveau ${ }^{33}$ op het moment van indiensttreding voor zowel mannen als vrouwen vergeleken met het moment van onderzoek (zomer 1987). Uit deze gegevens blijkt, dat mannen beduidend vaker zijn doorgestroomd naar hogere functieniveaus dan vrouwen (zie tabel 18). Voor een deel is dit verschil tussen de beide sexen een gevolg van het feit dat mannen gemiddeld een groter aantal dienstjaren hebben, dan vrouwen (10,5 versus 6,0 dienstjaren).

Tabel 18. Percentage doorstroming van mannen en vrouwen tussen het moment van indiensttreding en het moment van onderzoek

\begin{tabular}{lrrr} 
Van functieniveau & Totaal & Mannen & Vrouwen \\
\hline I naar II & 10,1 & 16,7 & 4,9 \\
I naar III & 13,8 & 28,9 & 1,9 \\
II naar III & 25,5 & 29,2 & 19,3 \\
II naar IV & 10,5 & 15,5 & 2,3 \\
III naar IV & 20,6 & 24,0 & 12,1 \\
IV naar V & 15,4 & 20,4 & 6,0 \\
V naar VI & 13,5 & 14,8 & 6,6 \\
\hline
\end{tabular}

Bron: LTD (1988)

Verschillen in arbeidsmarktpositie tussen beide sexen worden dan ook vaak toegeschreven aan het feit dat veel vrouwen hun loopbaan beëindigen of voor enige jaren onderbreken om (jonge) kinderen te verzorgen. Dat de verschillen tussen beide sexen wat betreft het hebben van leidinggevende functies echter niet alleen hierdoor verklaard kunnen worden blijkt wel uit onderzoek, dat in 1990 onder pas afgestudeerden ${ }^{34}$ van de Rijksuniversiteit Limburg is gehouden (Lodder e.a, 1991). Hoewel de gegevens zijn gecorrigeerd voor werkervaring, arbeidsduur, leeftijd, studierichting en een aantal relevante baan- en branchekenmerken blijken mannen significant vaker een leidinggevende positie te bekleden dan vrouwen. En dat terwijl deze mannen en vrouwen pas aan het begin van hun loopbaan staan! Beeldvorming van en over beide sexen lijkt op het verschil in leidinggeven derhalve eveneens een grote rol te spelen (zie ook Ott, 1985).

33. De (acht) functieniveaus, die de Loontechnische Dienst (LTD) onderscheidt, komen in grote lijnen overeen met de functieniveaus die ARBVO hanteert. Bij de LTD behoren de eerste drie niveaus tot het lage echelon; het vierde en vijfde niveau betreffen middelbare functies die zelfstandig worden uitgevoerd, terwijl de zesde $\mathrm{t} / \mathrm{m}$ achtste niveaus de hogere (leidinggevende, beleidsvoorbereidende en wetenschappelijke) functies omvatten.

34. Het gaat hier om alle oud-studenten die tussen 1986 en 1990 aan de Rijksuniversiteit Limburg zijn afgestudeerd. 
In een ander onderzoek constateren Nijsen, Peeters en Wennekers (1991), dat in het midden- en kleinbedrijf bij mannen grote verschillen bestaan naar leeftijd en beroepsgroep. Daarentegen vervullen jonge vrouwen dezelfde banen, c.q. beroepen als hun oudere sexegenoten. Bij vrouwen gaat het dan om slecht betaalde part-time banen met een laag functieniveau, zonder carrièreperspectief. Nijssen e.a. halen daarbij ook Van der Hauw aan die aangeeft dat "in tegenstelling tot de mannen het beroepsprofiel van vrouwen in het midden- en kleinbedrijf niet sterk naar leeftijd verschilt" (Van der Hauw, 1990 in: Nijsen e.a., 1991, blz. 42). In het middenen kleinbedrijf maken vrouwen (relatief) dus weinig carrière. Wanneer hieraan wordt toegevoegd, dat in de handels-, c.q. horecasector, welke een belangrijke component vormt in het midden- en kleinbedrijf, het gemiddeld aantal dienstjaren (voor zowel mannen als vrouwen) het kortste is (respectievelijk 8,9 en 4,1 versus 10,5 en 6,0 als gemiddeld aantal dienstjaren ${ }^{35}$ ), dan ontstaat al snel, zeker in combinatie met de gegevens over de sexespecifieke beroepssegregatie, het volgende beeld: vrouwen werken een aantal jaar in een aantal specifieke (lage) functies in het midden- en kleinbedrijf, vertrekken vervolgens uit het arbeidsproces en komen al dan niet als herintreedsters in dezelfde (lage) functies terug.

In de literatuur over arbeid en sexe wordt er regelmatig op gewezen, dat vrouwen zich meer dan mannen concentreren in bepaalde functies (zie ondermeer Van Mourik en Siegers, 1988, blz. 732-733). Dit geldt zowel voor de aard als het niveau van de functies. Hierbij dient men zich te realiseren, dat deze concentratie voor een deel echter het resultaat is van de daarvoor doorgaans gebruikte beroepenclassificatie van het CBS. De structuur van deze classificatie is namelijk van invloed op de uitkomsten van de segregatie-indices. Op de door het CBS onderscheiden aggregatieniveaus van de beroepenclassifictie blijken mannenberoepen telkens verder te zijn uitgesplitst dan vrouwenberoepen. Bovendien behoren mannenberoepen minder vaak tot de niet nader geïdentificeerde (rest)groepen en zijn de mannenberoepen, hoewel mannen een groter aandeel innemen op de arbeidsmarkt, kleiner naar het aantal beroepsbeoefenaren dan de vrouwenberoepen. Tijdens (in: Tijdschrift voor Arbeidsvraagstukken 1990/4, blz. 15-16) noemt hiervoor de volgende redenen. Ten eerste loopt de in 1968 ontworpen beroepenclassificatie achter in die zin, dat de industrieberoepen, die destijds een belangrijker aandeel in de werkgelegenheid innamen dan thans het geval is, gedetailleerder in de beroepenclassificatie zijn opgenomen dan de dienstverlenende beroepen, waarvan het aandeel de laatste jaren sterk is gegroeid. Ten tweede vermeldt zij dat De Kiewit en Teulings (1990) hebben opgemerkt, dat het 'Taylorisme' juist in de industrie tot een fijnmaziger afbakening van taken heeft geleid. Ten derde zouden vrouwenberoepen minder hiërarchisch van karakter zijn en zou (daarmee samenhangend) de beroepsidentiteit van vrouwen minder ontwikkeld of gespecificeerd zijn. Tenslotte merkt Tijdens op, dat de ontwerpers van de beroepenclassificatie, evenals de enquêteurs en codeurs wellicht zelf minder oog hebben (gehad) voor de identiteit van een aantal vrouwenberoepen. In ieder geval betekent dit dat de interpretatie van data over beroepssegregatie in het algemeen en het trekken van conclusies over het feit, dat vrouwen slechts in een aantal beroepen werkzaam zijn, met de nodige voorzichtigheid dient te

35. Over alle mannen en vrouwen in alle sectoren tezamen geldt een gemiddelde van 23 dienstjaren. 
geschieden (Tijdens in: Tijdschrift voor Arbeidsvraagstukken 1990/4, blz. 16). Mede om deze reden heeft het ROA inmiddels een beroepenclassificatie ontwikkeld, die is gebaseerd op een hergroepering van de CBS-beroepsgroepen (zie Dekker, De Grip en Van de Loo, 1990). Het uitgangspunt van deze ROA-beroepenclassificatie is te komen tot, naar de opleidingsachtergrond van de beroepsbeoefenaren, homogenere beroepsklassen dan de huidige beroepsklassen van het CBS. Door de sterke onderwijssegregatie naar sexe, zijn deze ROAberoepsklassen tevens homogener naar sexe dan de beroepsklassen die het CBS onderscheidt.

Aan het eind van deze paragraaf over de sexespecifieke onderwijs- en beroepssegregatie is het tenslotte interessant om te bezien in hoeverre de onderwijs- en beroepssegregatie aan elkaar zijn gerelateerd. Daarbij gaat het met name om de vraag hoe groot de beroepssegregatie is voor mensen met eenzelfde opleidingsachtergrond. Juist omdat de onderwijssegregatie naar opleidingsrichting zo pregnant is en naar opleidingsniveau zo marginaal, is nagegaan hoe groot de beroepssegregatie is voor beroepsbeoefenaren met respectievelijk een algemene, pedagogische, technische of agrarische, medisch of verzorgende, dan wel economische of juridische opleidingsachtergrond. De beleidsrelevante segregatie-index $S$ blijkt hierbij voor de sterk beroepsspecifieke opleidingen lager te zijn dan voor de algemeen opgeleiden. Deze index $\mathrm{S}$ varieert van $4 \%$ voor de technische en agrarische richting tot $25 \%$ voor de algemene richting. Voor alle tezamen (de indices gewogen met de opleidingstotalen in het geheel) is volgens Groot (1990) de beroepssegregatie binnen de opleidingsrichtingen, de zogenaamde 'nasortering', gelijk aan $14 \%$. Deze $14 \%$ van de nasortering komt in principe bovenop de $20 \%$ van de voorsortering binnen het onderwijs. Hierbij dienen wel twee kanttekeningen te worden gemaakt. Ten eerste tellen de voorsortering van $20 \%$ en de nasortering van $14 \%$ niet op tot de totale beroepssegregatie van $25 \%-30 \%$, omdat een verschil in opleidingsrichting tussen mannen en vrouwen niet automatisch betekent dat zij ook tot verschillende beroepen zullen behoren. Beide componenten van de totale beroepssegregatie kunnen elkaar voor een deel compenseren. Ten tweede kunnen er ook binnen de onderscheiden opleidingsrichtingen verschillende specifieke opleidingen bestaan, waarin ofwel mannen, ofwel vrouwen sterk zijn oververtegenwoordigd, terwijl deze opleidingen bovendien niet op dezelfde beroepssegmenten zijn gericht (bijvoorbeeld MEAO-commercieel versus MEAO-secretarieel binnen opleidingsrichting MBO economischadministratief \& juridisch).

De conclusie ten aanzien van de opleidings- en beroepssegregatie tussen mannen en vrouwen luidt derhalve dat een belangrijk deel van de totale beroepssegregatie haar oorsprong vindt in een vrij sterke voorsortering binnen het onderwijstraject, maar dat in het daaropvolgende loopbaantraject de beroepssegregatie verder wordt versterkt. Bovendien blijken beide vormen van segregatie slechts geleidelijk te veranderen. 


\section{WERKGELEGENHEIDSSTRUCTUUR}

In dit hoofdstuk zal verder worden ingegaan op de wijze waarop de werkgelegenheid van mannen en vrouwen is gestructureerd. In de tachtiger jaren is de structuur van de werkgelegenheid onder invloed van ondermeer de economische recessie begin jaren tachtig en het krachtige economische herstel daarna, evenals door verschuivingen in de internationale arbeidsverdeling en het proces van technologische vernieuwing aanzienlijk veranderd (zie ook De Grip, 1986, 1987 in Huygen, 1989, blz. 7). De vraag is nu of de werkgelegenheidsstructuur zich voor mannen en vrouwen de laatste tien jaar op dezelfde wijze heeft ontwikkeld. Voor een deel is deze vraag beantwoord aan de hand van trends in de beroepssegregatie tussen beide sexen. De conclusie luidde aldaar dat deze segregatie tussen mannen en vrouwen nog in hoge mate aanwezig is en dat de geringe afname (van de index s) met name betrekking heeft op de participatie van mannen in vrouwenberoepen (in plaats van vrouwen in mannenberoepen) en dat een aantal verticale segregatietendensen de lichte vermindering van de horizontale beroepssegregatie deels teniet doen.

In dit hoofdstuk zal aan de volgende aspecten van de werkgelegenheidsstructuur, en met name aan de discrepanties daarin tussen beide sexen, aandacht worden geschonken. Allereerst zal in paragraaf 4.1. worden nagegaan in hoeverre er verschillen bestaan tussen mannen en vrouwen voor wat betreft hun het dienstverband waarin zij werkzaam zijn. Enerzijds gaat het hierbij om de positie die zij in hun werkkring innemen, anderzijds om het soort arbeidscontract dat zij met hun werkgever zijn aangegaan. Vervolgens zal in paragraaf 4.2. worden aangegeven hoe beide sexen in de nabije toekomst in de zogenaamde 'groei-', en 'krimpberoepen' zijn vertegenwoordigd. Groeiberoepen zijn beroepsklassen, die naar verwachting in de periode 19891994 in omvang zullen toenemen, terwijl krimpberoepen juist beroepsklassen vertegenwoordigen die onder invloed van ontwikkelingen in de werkgelegenheidsstructuur in omvang zullen afnemen. Tenslotte wordt aan de hand van analyses van Huygen (1989) in paragraaf 4.3. een beeld geschetst van de aansluiting tussen opleiding en functieniveau, gedifferentieerd naar sexe.

\subsection{Dienstverband naar sexe}

Tabel 19. Positie in de werkkring naar sexe in 1979, 1985, 1987 en 1989 in procenten

\begin{tabular}{lllllll}
\hline & \multicolumn{2}{l}{ Zelfstandigen } & & \multicolumn{2}{c}{ Meewerkend Gezinslid } & In Loondienst \\
Jaar & Man & Vrouw & Man & Vrouw & Man & Vrouw \\
& & & & & & \\
1979 & 12,1 & 3,7 & 0,5 & 7,8 & 87,4 & 88,3 \\
1985 & 11,4 & 4,3 & 0,4 & 6,1 & 88,3 & 89,6 \\
1987 & 10,6 & 8,1 & 0,6 & 5,0 & 88,7 & 86,9 \\
1989 & 10,6 & 7,5 & 0,3 & 4,7 & 89,1 & 87,8 \\
\hline
\end{tabular}

Bron: CBS/ROA 
De positie in de werkkring valt uiteen in drie categorieën: zelfstandigen, meewerkende gezinsleden en in loondienst werkenden. In tabel 19 staat voor de jaren 1979, 1985, 1987 en 1989 aangegeven in hoeverre er hierin verschillen bestaan tussen mannen en vrouwen.

Zowel bij mannen als vrouwen werkt het overgrote deel (circa $88 \%$ ) in loondienst. De grootste verschillen tussen beide sexen hebben betrekking op enerzijds het aandeel zelfstandige ondernemers en anderzijds het aandeel dat meewerkt in het bedrijf van de partner. Mannen zijn (verhoudingsgewijs) vaker als zelfstandig ondernemer werkzaam, terwijl vrouwen absoluut en relatief veelvuldiger als meewerkend gezinslid ${ }^{36}$ arbeid verrichten. In de tachtiger jaren is het percentage zelfstandigen onder vrouwen echter wel sterk toegenomen ten koste van de percentages van meewerkende gezinsleden en vrouwen die in loondienst werken. Brouns en Schokker (1990, blz. 42) merken overigens op, dat zelfstandige vrouwen verhoudingsgewijs kleine bedrijven hebben. Van deze 'vrouwenbedrijven' heeft namelijk $86 \%$ de vorm van een éénpersoonsonderneming, terwijl gemiddeld $60 \%$ van de bedrijven een dergelijke onderneming betreft.

Tabel 20. Soort arbeidscontract van personen in loondienst naar sexe in 1983, 1985, 1987 en 1989 in procenten

\begin{tabular}{|c|c|c|c|c|c|c|c|c|}
\hline \multirow[b]{2}{*}{ Arbeidscontract } & \multicolumn{2}{|c|}{1983} & \multicolumn{2}{|c|}{1985} & \multicolumn{2}{|c|}{1987} & \multicolumn{2}{|c|}{1989} \\
\hline & $M$ & V & M & V & M & V & $M$ & V \\
\hline Vast & 94 & 90 & 92 & 88 & 91 & 87 & 92 & 89 \\
\hline Tijdelijk & 6 & 10 & 8 & 12 & 9 & 13 & 8 & 11 \\
\hline
\end{tabular}

Bron: $\mathrm{CBS} / \mathrm{ROA}$

Ook de aard van het dienstverband kan een indicatie zijn voor de kwalitatieve structuur van de werkgelegenheid van vrouwen, zoals Brouns en Schokker (1990, blz. 33) opmerken. Mannen hebben vaker een vast contract dan vrouwen, die zoals blijkt uit het OSA-rapport uit 1989 (Huijgen, 1989) verhoudingsgewijs vaker een tijdelijke of flexibele arbeidsrelatie ${ }^{37}$ hebben. Hoewel midden jaren tachtig zowel bij mannen als bij vrouwen het aandeel van de vaste arbeidsovereenkomsten is teruggelopen, blijken werknemers in 1989 weer vaker een vast contract te hebben (zie tabel 20). Wellicht dat de ontgroening, evenals de krapte in een aantal

36. Het Burgerlijk Wetboek verbiedt arbeidsovereenkomsten tussen echtelieden. Door het huwelijk zijn (meestal) vrouwen verbonden aan een bedrijf, dat ze meestal niet zelf bezitten/beheren. Ze zijn geen ondernemers/werkgevers, maar (wettelijk) evenmin werknemers. Het gevolg hiervan is dat deze vrouwen geen beroep kunnen doen op werknemers-verzekeringen, noch aanspraak kunnen maken op ziekte- en zwangerschapsverlof e.d. (zie verder Brouns en Schokker, 1990, blz. 154-157).

37. Hierbij gaat het om tijdelijke contracten, al dan niet met uitzicht op een vast contract, werk via uitzendbureaus, oproep-, evenals stage- en leercontracten. 
segmenten op de arbeidsmarkt hierbij een rol spelen. Immers, met het toenemen van respectievelijk de leeftijd en de (onvervulde) vraag naar arbeid neemt het aandeel van tijdelijke banen af. Tussen 1983 en 1989 is het verschil tussen mannen en vrouwen ten aanzien van het aandeel dat een vaste arbeidsovereenkomst heeft overigens nagenoeg gelijk gebleven.

Tabel 21. Reden voor tijdelijk contract van personen in loondienst (exclusief militair dienstplichtigen) naar sexe in 1989 in procenten

Reden tijdelijk contract Mannen Vrouwen

$\begin{array}{lrr}\text { Contract voor duur v/d opleiding } & 8,8 & 6,1 \\ \text { Kon alleen tijdelijke aanstelling krijgen } & 62,1 & 66,8 \\ \text { Wilde tijdelijk contract } & 11,5 & 14,0 \\ \text { Andere redenen }^{38} & 17,6 & 13,1\end{array}$

Bron: CBS

In bijna tweederde van de gevallen blijkt een tijdelijk contract aanvaard te zijn, omdat men alleen een tijdelijke aanstelling kon verwerven. De toename van tijdelijk werk lijkt derhalve met name aan de vraagzijde van de markt te zijn geïnduceerd. Het verschil tussen beide sexen blijkt voor alle aangevoerde redenen overigens vrij gering te zijn.

\subsection{Aandeel van sexen in groei- en krimpberoepen}

Zoals in de paragraaf 3.3. over de beroepssegregatie reeds is aangegeven, blijkt in de periode 1979-1985 met name de werkgelegenheid in de beroepsgroepen waarin vrouwen zijn oververtegenwoordigd, te zijn gegroeid (zie ook Van Mourik en Siegers, 1988). In deze paragraaf wordt aangegeven hoe vrouwen vertegenwoordigd zijn in de beroepsklassen die naar verwachting in de nabije toekomst qua omvang zullen toe-, dan wel afnemen. Uit de resultaten van het ROA-informatiesysteem onderwijs-arbeidsmarkt $1990^{39}$ dat betrekking heeft op de prognoseperiode 1989-1994, blijken onderstaande beroepsklassen (CBS, 2-digit) tot de 'groei-', dan wel 'krimpberoepen' te kunnen worden geclassifeerd. Het gaat hier om de tien ${ }^{40}$ beroepsklassen, die absoluut en/of relatief ten opzichte van het aantal werkenden in de betreffende beroepsklasse in 1989 respectievelijk de sterkst groeiende dan wel sterkst

38. Dit heeft enerzijds betrekking op mensen die gaan studeren of in militaire dienst gaan, omdat zij na afloop van het contract niet verder kunnen werken en anderzijds op mensen die i.v.m. bezuinigingen of diverse andere redenen een tijdelijk contract hebben (CBS, 1990).

39. Zie Dekker, De Grip, Beekman, Van de Loo, Wieling en Willems, 1990.

40. Doordat niet alle genoemde beroepsklassen èn absoluut èn relatief tot de tien meest groeiende dan wel krimpende beroepsklassen kunnen worden gerekend, worden er meer dan tien in de tabel opgenomen. 
krimpende beroepsklassen $\mathrm{zijn}^{41}$. Van al deze beroepsklassen is eveneens het percentage vrouwen aangegeven, dat in 1985 werkzaam is in de betreffende beroepsklasse.

Tabel 22. Sterkst groeiende beroepsklassen 1989-1994; absoluut (x 1000; afgerond) en/of relatief t.o.v. het aantal werkenden in de beroepsklasse in 1989 en percentage vrouwen in die beroepsklasse in 1985

\section{Code Beroepsklasse}

abs.groei

\% groei

$\begin{array}{rrr}46,6 & 25 & 17 \\ 45,4 & 57 & 6 \\ 42,3 & 20 & 5 \\ 29,7 & 10 & 70 \\ 22,0 & 36 & 11 \\ 21,2 & 11 & 1 \\ 20,2 & 7 & 71 \\ 12,6 & 4 & 36 \\ 12,3 & 12 & 17 \\ 10,7 & 3 & 45 \\ 7,4 & 26 & 20 \\ 4,6 & 12 & 5 \\ 3,5 & 12 & 4 \\ 2,1 & 12 & 12\end{array}$

$\begin{array}{lll}\text { Gemiddelde \% groei alle beroepsklassen } & 6 & 23 \\ \text { Gemiddeld \% vrouwen in groeiberoepen } & & 34\end{array}$

\begin{tabular}{ll} 
Gemiddeld \% vrouwen in werkgelegenheid & 34 \\
\hline
\end{tabular}

Bron: ROA

Bij de 'groeiberoepen' blijken vier van de veertien beroepsklassen een, gezien hun aandeel in de totale werkgelegenheid, oververtegenwoordiging van vrouwen te kennen. Het gaat om de beroepsklassen van winkelbedienden en andere verkopers, genees- en verpleegkundigen, (niet eerder genoemde) administratieve functies, alsmede boekhouders en loketemployees. Dit zijn omvangrijke beroepsklassen, die juist daardoor absoluut gezien in de periode 1989-1994 sterk zullen uitbreiden, maar die ten opzichte van het aantal in die beroepsklasse werkenden echter belangrijk minder zullen stijgen. Beroepsklassen met een relatieve oververtegenwoordiging van vrouwen zijn in de 'groeiberoepen' ongeveer gelijk vertegenwoordigd als in alle beroepsklassen tezamen (hun aandeel varieert tussen de $25 \%$ en $30 \%$ ). Bij de 'krimpberoepen' komt echter slechts eenmaal een beroepsklasse met een relatieve oververtegenwoordiging van vrouwen voor. Deze beroepsklasse van telefonisten en telegrafisten blijkt echter wel de relatief sterkst krimpende beroepsklasse te zijn.

41. Bij de definiëring van groei- en krimpberoepen gaat het om de (mogelijke) verandering in de werkgelegenheidsstructuur. Derhalve is alleen de uitbreidings- en niet de vervangingsvraag bij de bepaling van deze beroepen betrokken. 
Tabel 23. Sterkst krimpende beroepsklassen 1989-1994; absoluut (x 1000; afgerond) en/of relatief t.o.v. het aantal werkenden in de beroepsklasse in 1989 en percentage vrouwen in die beroepsklasse in 1985

\begin{tabular}{|c|c|c|c|c|}
\hline Code & Beroepsklasse & abs.krimp & $\%$ krimp & $\%$ vrouwen \\
\hline 45 & Verkoop-/inkoopchefs e.d. & $-7,1$ & -18 & 15 \\
\hline 83 & Smeden, gereedsschapsmakers & $-3,9$ & -14 & 1 \\
\hline 61 & Zelfstandige Land-/tuinbouwers & $-3,5$ & -33 & \\
\hline 38 & Telefonisten, telegrafisten & $-3,3$ & -23 & 81 \\
\hline $76 / 80$ & Schoen- en lederwarenmakers & $-3,3$ & -5 & 30 \\
\hline 95 & Metselaars e.a. bouwvakkers & $-3,2$ & -2 & 1 \\
\hline 62 & Agrarische arbeiders & $-2,3$ & -2 & 28 \\
\hline 92 & Drukkers en drukkerijpersoneel & $-2,1$ & -5 & 11 \\
\hline 98 & Chauffeurs, matrozen e.d. & $-1,4$ & -1 & 2 \\
\hline 85 & Electromonteurs, -reparateurs & $-1,1$ & -1 & 7 \\
\hline 75 & Spinners, wevers, ververs & $-0,4$ & -3 & 16 \\
\hline 78 & Tabaksproduktenmakers & $-0,3$ & -11 & 21 \\
\hline 91 & Papierwaren- en kartonwerkers & $-0,2$ & -5 & 12 \\
\hline 36 & Conducteurs trein, tram, bus & $-0,2$ & -5 & 0 \\
\hline 71 & Mijn- en groeve-arbeiders & $-0,1$ & -7 & 4 \\
\hline \multirow{3}{*}{\multicolumn{2}{|c|}{$\begin{array}{l}\text { Gemiddelde \% krimp alle beroepsklassen } \\
\text { Gemiddeld \% vrouwen in krimpberoepen } \\
\text { Gemiddeld \% vrouwen in werkgelegenheid }\end{array}$}} & & 6 & \\
\hline & & & & 15 \\
\hline & & & & 34 \\
\hline
\end{tabular}

Bron: ROA

De vraag is nu hoe deze verwachtingen ten aanzien van de ontwikkelingen in de werkgelegenheidsstructuur, waarin vrouwenberoepen niet zijn oververtegenwoordigd in de 'groeiberoepen', rijmen met de constatering dat in de periode 1979-1985 juist in typisch 'vrouwelijke' beroepsklassen de werkgelegenheid is toegenomen (Van Mourik en Siegers, 1985). Afgezien van het feit dat de ontwikkelingen uit het recente verleden uiteraard niet hoeven te sporen met verwachtingen voor de nabije toekomst, is voor deze discrepantie nog een verklaring aan te wijzen. Deze verklaring houdt verband met de hoge vervangingsvraag in met name vrouwenberoepen, welke niet is verdisconteerd in de definiëring van het begrip 'groeiberoep', maar wel in de analyses van de werkgelegenheid voor mannen en vrouwen van Van Mourik en Siegers (1985), evenals die van Huijgen (1989). Zo blijken zeven van de tien beroepsklassen met absoluut gezien de hoogste verwachte vervangingsvraag in de periode 1989-1994 beroepsklassen met een relatieve oververtegenwoordiging van vrouwen te betreffen (zie Rapportage I-SEE! 1990 van Dekker e.a., 1990).

\subsection{Aansluiting tussen opleiding en functieniveau naar sexe}

De ontwikkelingen in de kwalitatieve structuur van de werkgelegenheid en de daarin vóórkomende discrepanties tussen beide sexen kunnen eveneens op basis van een analyse van de functieniveaustructuur worden bestudeerd. Aan de hand van een dergelijke studie van Huijgen (1989) zal hieronder een overzicht worden gegeven van de veranderingen tussen 1977 en 1985 in het functieniveau van de werkzame beroepsbevolking, alsmede de aansluiting tussen 
de opleiding van werknemers en het functieniveau van hun betaalde baan. Hierbij zal in het bijzonder aandacht worden besteed aan de geslachtsspecifieke ongelijkheid, evenals de ontwikkelingen daarin. De aansluitingsproblematiek wordt daarbij benaderd vanuit het gezichtspunt van de aanbieders van arbeid, in casu de werknemers.

Huijgen heeft reeds eerder vastgesteld dat de kansen op 'passende arbeid' en de ontwikkelingen daarin in de periode 1960-1977 voor vrouwen over het algemeen minder positief zijn dan voor mannen. Immers, "de beroepshoogte van vrouwen is veelal lager dan die van mannen en de ontwikkelingen in het gemiddelde functieniveau van vrouwen zijn doorgaans minder positief, c.q. negatiever dan voor mannen, ook wanneer gecontroleerd wordt voor verschillen in opleiding, leeftijd en andere al dan niet persoonsgebonden kenmerken" (Huijgen, 1989, blz. 54). Voor de periode 1979-1985 kan deze lijn (helaas) worden doorgetrokken. Bij mannen is het gemiddelde functieniveau namelijk sterker toegenomen dan bij vrouwen, zodat het verschil tussen beide sexen in functieniveau ten nadele van vrouwen verder is gestegen (Huijgen, 1989, blz. 56).

Tabel 24. De verdeling van vrouwen over de functieniveaus en het aandeel van vrouwen in 1987 in procenten

\begin{tabular}{lcc}
\hline & $\%$ in totaal & $\%$ vrouwen \\
Functieniveau & & \\
\hline niveau I & 6,4 & 71,0 \\
niveau II & 21,2 & 47,0 \\
niveau III & 35,8 & 30,6 \\
niveau IV & 23,1 & 27,5 \\
niveau V & 8,7 & 14,1 \\
niveau VI & 4,0 & 6,7 \\
niveau VII & 0,7 & 1,3 \\
niveau VIII & 0,0 & -- \\
Totaal & $100 \%$ & $33,4 \%$ \\
\hline
\end{tabular}

Bron: LTD

Wanneer het aandeel van vrouwen per functieniveau in tabel 24 in ogenschouw wordt genomen, dan blijkt dan ook dat op het laagste functieniveau bijna driekwart van de werkenden uit vrouwen bestaat, terwijl het één na hoogste functieniveau nog slechts $1,3 \%$ vrouwen bevat (Loontechnische Dienst, 1988, blz. 30). Ruim $80 \%$ van de vrouwen heeft een baan op functieniveau II, III of IV.

Bij bestudering van de ontwikkeling van het gemiddelde functieniveau per opleidingsniveau dat de werkenden hebben genoten blijkt, dat zowel voor mannen als voor vrouwen het functieniveau tussen 1977 en 1985 is gedaald. Deze achteruitgang treft echter, uitgezonderd de academisch geschoolde vrouwen, in hogere mate de vrouwelijke werknemers, zodat, met uitzondering van de academici, ook in dit opzicht de geslachtsspecifieke ongelijkheid is 
toegenomen (Huijgen, 1989, blz. 59).

In 1977 bleek de mate van onderbenutting ${ }^{42}$ per opleidingsniveau tussen beide sexen nog nauwelijks van elkaar te verschillen. Alleen vrouwen met een opleiding op uitgebreid lager niveau bleken toen verhoudingsgewijs vaker onderbenut. Sedertdien is de onderbenutting echter sterker onder vrouwen toegenomen dan onder mannen. Dit geldt met name voor vrouwen met een middelbare of semi-hogere opleiding (Huijgen, 1989, blz. 60-61). De ongelijkheid tussen mannen en vrouwen met betrekking tot de kansen op 'passende arbeid' blijken nauwelijks specifiek te zijn voor een bepaalde opleidingsrichting. Huijgen (1989, blz. 64) concludeert dan ook dat in zijn algemeenheid deze ongelijkheid tussen beide sexen toeneemt.

Ook de Loontechnische dienst (1988, blz. 37-38) laat zien, dat vrouwen vaker worden onderbenut dan mannen. Met uitzondering van het laagste functieniveau blijken namelijk op alle andere functieniveaus vrouwen gemiddeld een hoger opleidingsniveau te hebben dan mannen.

In hoofdstuk 6 zal overigens voor een aantal typische vrouwenopleidingen nog verder worden ingegaan op de onderbenutting van degenen die met de betreffende opleiding als hoogste onderwijskwalificatie werkzaam zijn.

Tenslotte is Huijgen (1989, blz. 64-67) nagegaan in hoeverre er een samenhang bestaat tussen de kans op 'passende arbeid' en deeltijdarbeid. Een korte deeltijdbaan (met een werkweek van minder dan 15 uur) blijkt voor vrouwen met een lagere scholing relatief vaker in een lager gemiddeld functieniveau te resulteren, dan voor vergelijkbare vrouwen met een full-time baan. Voor vrouwen met een (semi-)hogere opleiding blijkt werken in deeltijd geen negatieve gevolgen te hebben voor het gemiddeld functieniveau. Enerzijds zijn er bij de overheid en instellingen in de quartaire sector relatief veel deeltijdbanen voor mensen (lees vrouwen) met een (semi-)hogere (sociale of pedagogische) opleidingsachtergrond. Anderzijds zullen verhoudingsgewijs meer mannen, ondanks het hoge functieniveau van deze banen, niet een dusdanig 'kleine' baan accepteren.

42. Een werknemer wordt over-, c.q. onderbenut indien het functieniveau van zijn/haar baan, door Huijgen bepaald op basis van de beroepenclassificatie van ARBVO, respectievelijk te hoog, dan wel te laag is in vergelijking met de door hem of haar hoogst behaalde onderwijs-kwalificatie. 


\section{ARBEIDSMARKTKARAKTERISTIEKEN VROUWENBEROEPEN}

\subsection{Inleiding}

In hoofdstuk zal een aantal arbeidsmarktkenmerken van een tiental typisch 'vrouwelijke' beroepsklassen (CBS, 2 digit) worden besproken. Het gaat hierbij om de tien beroepsklassen met het hoogste aandeel vrouwen in 1985 (zie onderstaande tabel). In feite gaat het niet om de karakteristieken van deze vrouwenberoepen zelf, maar om de kenmerken van de beroepsbeoefenaren in deze beroepen.

Tabel 25. Werkzame vrouwen in vrouwenberoepen in 1979 en 1985, absoluut (x 1000; afgerond), percentage vrouwen in klasse en percentage van totale werkgelegenheid vrouwen

\begin{tabular}{|c|c|c|c|c|c|c|c|}
\hline \multirow[b]{2}{*}{ Code } & \multirow[b]{2}{*}{ Beroepsklasse } & \multicolumn{2}{|c|}{ absoluut } & \multicolumn{2}{|c|}{$\%$ vrouwen } & \multicolumn{2}{|c|}{$\begin{array}{l}\% \text { in tot. werk } \\
\text { zame vrouwen }\end{array}$} \\
\hline & & 79 & '85 & $' 79$ & '85 & $' 79$ & $' 85$ \\
\hline $6 / 7$ & Verpleeg- en geneeskundigen & 139 & 192 & 71 & 72 & 10 & 11 \\
\hline 32 & Secretaressen, typisten & 135 & 142 & 97 & 95 & 10 & 8 \\
\hline 38 & Telefonisten, telegrafisten & 14 & 15 & 81 & 82 & 1 & 1 \\
\hline 48 & Winkelbedienden e.a. verkopers & 159 & 164 & 70 & 71 & 11 & 10 \\
\hline 54 & Verzorgend en huishoudelijk personeel & 154 & 173 & 96 & 96 & 11 & 10 \\
\hline 55 & Schoonmakers, conciërges & 70 & 101 & 70 & 74 & 5 & 6 \\
\hline 56 & Wasserijpersoneel & 6 & 7 & 58 & 72 & 0 & 0 \\
\hline 57 & Kappers, schoonheidsspecialisten & 19 & 24 & 67 & 77 & 1 & 1 \\
\hline 59 & Dienstverlenende functies n.e.g. & 16 & 20 & 60 & 68 & 1 & 1 \\
\hline 79 & Confectiemakers, stoffeerders & 25 & 21 & 65 & 66 & 2 & 1 \\
\hline \multirow{4}{*}{\multicolumn{2}{|c|}{$\begin{array}{l}\text { absoluut totaal vrouwen in vrouwenberoepen } \\
\% \text { vrouwen in totaal werkzame personen } \\
\text { Gemiddeld \% vrouwen per vrouwenberoep } \\
\text { Som \% vrouwenberoepen in totaal werkzame } \\
\text { vrouwen }\end{array}$}} & 737 & 859 & & & & \\
\hline & & & & 29 & 34 & & \\
\hline & & & & 74 & 77 & & \\
\hline & & & & & & 52 & 49 \\
\hline
\end{tabular}

Bron: CBS/ROA

Bovengenoemde 'vrouwelijke' beroepsklassen zijn af en toe samengesteld uit een aantal beroepsgroepen, waarvan er een aantal als typisch 'vrouwelijk' aangemerkt kan worden, maar eveneens enkele als typisch 'mannelijk'. Deze beroepsklassen zijn naar sexe heterogeen opgebouwd, wat tevens consequenties heeft voor de gegevens over een aantal arbeidsmarktkenmerken. Deze heterogeniteit naar sexe heeft betrekking op de volgende beroepsklassen:

- verpleeg- en geneeskundigen: circa de helft van de werkenden behoort tot het (voornamelijk vrouwelijk) verplegend personeel, terwijl de andere helft bestaat uit (met name mannelijke) artsen en apothekers en (merendeels) vrouwelijke paramedische therapeuten en apothekersassistenten;

- confectiemakers en stoffeerders: ruim $40 \%$ van deze beroepsklasse betreft de 'vrouwelijke' beroepsgroep van confectienaaisters; $30 \%$ heeft betrekking op de 'mannelijke' beroepsgroep 
van meubel- en woningstoffeerders;

- schoonmakers en conciërges: $85 \%$ van de werkzame personen heeft werk als schoonmaker, glazenwasser of schoorsteenveger, terwijl $15 \%$ als conciërge werkzaam is;

- dienstverlenende functies n.e.g. (niet eerder genoemd): $57 \%$ van de werkenden uit deze beroepklasse is dokter-, tand- of dierenartsassistent; ruim $40 \%$ is werkzaam in én van de niet nader gespecificeerde dienstverlenende beroepen.

In een enkel geval bestaat de beroepsklasse uit meerdere nogal uiteenlopende vrouwenberoepen. Zo omvat de beroepsklasse van het verzorgende en huishoudelijke personeel enerzijds de bejaarden-, gezins- en kinderverzorgers en anderzijds de beroepsgroep van kamermeisjes, hotelportiers en hostessen. Bovendien zijn in beroepsklasse 57 zowel kappers, schoonheidsspecialisten, als saunamedewerkers opgenomen.

Vanwege de grote heterogeniteit van de door het CBS onderscheiden beroepsklassen, is het ROA recentelijk gebruik gaan maken van een beroepenclassificatie, die gebaseerd is op een hergroepering van de CBS-beroepsgroepen $(3 \mathrm{digit})^{43}$. De (93) ROA-beroepsklassen zijn namelijk homogener naar opleidingsachtergrond van de beroepsbeoefenaren dan de huidige (82) CBS-beroepsklassen en sluiten daardoor beter aan bij de in de praktijk bestaande arbeidsmarktsegmenten. Mede door de geslachtsspecifieke opleidingssegregatie zijn typische 'mannen-' en vrouwenberoepen bij deze ROA-beroepenindeling derhalve minder vaak samengevoegd in één beroepsklasse, zodat de spreiding van het aandeel van vrouwen tussen verscheidene beroepsgroepen binnen én beroepsklasse bij het gebruik van de ROAberoepenclassificatie kleiner is dan bij het hanteren van de CBS-beroepsklassen. De huidige (zeer omvangrijke) en heterogene CBS-beroepsklasse 06/07 bijvoorbeeld wordt in de ROABeroepenclassificatie gesplitst in een negental nieuwe beroepsklassen. Omgekeerd zijn in de ROA-Beroepenclassificatie een groot aantal industrieel-ambachtelijke beroepen, die, gezien de opleidingsachtergrond van de beroepsbeoefenaren, tot hetzelfde arbeidsmarktsegment gerekend kan worden, juist samengevoegd. Het ROA verwacht met behulp van de nieuwe beroepenclassificatie met name ook de arbeidsmarktpositie van vrouwen beter te kunnen typeren.

Bij de analyse van de arbeidsmarktkenmerken van de onderscheiden beroepsklassen kan de heterogeniteit van de beroepsklassen voor wat betreft sexeverhouding en opleidingsachtergrond dus niet uit het oog worden verloren.

Op de beroepsklasse van de confectiemakers en stoffeerders na, kunnen de beroepsklassen met het hoogste aandeel vrouwen (hierna: vrouwenberoepen) gerekend worden tot de dienstverlenende beroepen. In 1985 heeft de beroepsklasse van verzorgend en huishoudelijk personeel met $96 \%$ het hoogste aandeel vrouwen, terwijl de beroepsklasse van confectie- en

43. Helaas was het niet mogelijk reeds bij dit werkdocument uit te gaan van deze ROABeroepenclassificatie. 
stoffeerders voor circa tweederde uit vrouwen bestaat ${ }^{44}$.

Circa de helft van de werkgelegenheid van vrouwen, gemeten in personen, wordt gevormd door bovengenoemde tien vrouwenberoepen, waarvan de grootste vijf beroepsklassen ruim $45 \%$ voor hun rekening nemen. In afnemende betekenis gaat het hier om de beroepsklassen van de verpleeg- en geneeskundigen, het verzorgend en huishoudelijk personeel, de winkelbedienden en andere verkopers, de secretaressen en typisten, alsmede om de klasse van schoonmakers en conciërges. Naast deze vijf vrouwenberoepen nemen de beroepsklassen met betrekking tot boekhoudkundige functies, diverse niet nader gespecificeerde administratieve functies, evenals de leerkrachten een belangrijke plaats binnen de werkgelegenheid van vrouwen in (circa $25 \%$ ).

Zoals in het totaal van de werkzame personen het percentage vrouwen in de periode 19791985 van $29 \%$ naar $34 \%$ is gestegen, is eveneens het aandeel van vrouwen in de vrouwenberoepen toegenomen; namelijk van $74 \%$ naar $77 \%$. Echter het aandeel van deze vrouwenberoepen in de totale werkgelegenheid van vrouwen is in deze periode licht gedaald (van 52\% naar 49\%). Met andere woorden, doordat vrouwen meer dan mannen zijn toegetreden tot de arbeidsmarkt is het aandeel van vrouwen in het grootste gedeelte van de beroepsklassen (dus ook in de vrouwenberoepen) toegenomen. Deze toename is niettemin relatief minder sterk geweest in de vrouwenberoepen (zie ook Van Mourik en Siegers, 1988).

Tussen 1979 en 1985 is bij driekwart van alle beroepsklassen het percentage vrouwen gestegen. Het is interessant om te zien bij welken typen beroepsklassen het aandeel van vrouwen juist niet is toegenomen. Men kan in dit verband drie typen onderscheiden. Ten eerste lijkt er bij een aantal typisch 'vrouwelijke' beroepsklassen een verzadigingspunt wat betreft het aandeel vrouwen op te treden. Dit geldt voor de beroepsklassen van secretaressen en typisten, evenals het verzorgend en huishoudelijk personeel. In de tweede plaats is in deze periode het percentage vrouwen afgenomen in beroepsklassen van leidinggevend personeel in sectoren, waarin van oudsher vrouwen goed vertegenwoordigd zijn. Dit geldt bijvoorbeeld voor de beroepsklassen van directeuren en bedrijfsleiders in de detailhandel en in de horeca, evenals in de land- en tuinbouw. Ook bij het leidinggevend huishoudelijk personeel, alsmede bij de leerkrachten en de uitvoerende hoofdambtenaren is het aandeel van vrouwen gedaald. Tenslotte blijkt bij zo'n tiental beroepsklassen van uiteenlopende technische (industrieel-ambachtelijke) vaklieden het aandeel van vrouwen, dat vaak al zeer laag is, tussen 1979 en 1985 afgenomen te zijn. Juist omdat in de beroepsklasse van niet nader gespecificeerd industrieel-ambachtelijk personeel, het zogenaamde 'lopende bandwerk', het percentage vrouwen in deze periode zo fors (van $13 \%$ tot $24 \%$ ) is gestegen, lijkt in de industrie in enige mate sprake te zijn van 'polarisatie'. Kort en (wellicht te) bondig gezegd: met het (verder) automatiseren van de produktie wordt de arbeidsorganisatie zo ingericht, dat vrouwen de kort cyclische en eenvoudigste handelingen (gaan) verrichten, terwijl mannen zich meer gaan bezighouden met het instellen en repareren van het machinepark (zie ook Trommel en Poutsma, 1990).

44. Binnen deze beroepsklasse blijkt de beroepsgroep van confectienaaiers echter voor $96 \%$ uit vrouwen te bestaan, terwijl slechts $21 \%$ van de stoffeerders een vrouw betreft. 


\subsection{Opleidingsprofiel vrouwenberoepen}

In bijlage 1 is een overzicht opgenomen van het zogenaamde opleidingsprofiel van de vrouwenberoepen. Het gaat hier om de belangrijkste ${ }^{45}$ opleidingsachtergronden van de beroepsbeoefenaren in de vrouwenberoepen in 1985, waarbij de gegevens zijn gedifferentieerd naar sexe.

Er blijkt een groot verschil te bestaan tussen beide sexen voor wat betreft de opleidingsachtergronden van de beroepsbeoefenaren in de tien onderscheiden vrouwenberoepen. Mannen blijken dus dikwijls vanuit geheel andere opleidingen door te stromen naar één van de vrouwenberoepen dàn vrouwen. Hiervoor kunnen verschillende verklaringen worden gegeven.

Ten eerste bestaat een aantal van de onderscheiden vrouwenberoepen uit een (te) heterogene verzameling van beroepsgroepen en beroepen. De beroepsklasse van 'verpleeg- en geneeskundigen' is hiervan het duidelijkste voorbeeld. Mannen en vrouwen hebben in deze beroepsklasse met name zulke verschillende opleidingsachtergronden, omdat het door hen gevolgde onderwijs naar verschillende beroepsgroepen leidt. Mannen vervullen in deze beroepsklasse vaker een geneeskundige functie uit, terwijl vrouwen zijn oververtegenwoordigd in de verpleegkundige functies. Dit verschil in beroep tussen beide sexen wordt dus weerspiegeld in de opleidingsachtergronden van mannen en vrouwen in deze beroepsklasse.

Doch ook bij andere vrouwenberoepen speelt deze heterogeniteit van de beroepsklasse een rol bij de verschillen tussen mannen en vrouwen in opleidingsachtergrond. Dit geldt bijvoorbeeld voor de beroepsklasse van schoonmakers en conciërges, waarin vrouwen meestal een baan als schoonmaakster hebben en mannen zijn oververtegenwoordigd in beroepen als conciërge of huisbewaarder. Binnen de beroepsklasse van confectiemakers en stoffeerders, zijn vrouwen voor een belangrijk deel als confectienaaister werkzaam, terwijl mannen daarentegen vaak stoffeerder zijn. In beide beroepsklassen zien we dan ook dat mannen vaak een technische opleiding genoten hebben, terwijl vrouwen vaker verzorgend onderwijs of een beroepsspecifieke opleiding $^{46}$ hebben gevolgd. Tenslotte nog een opmerking over de heterogene 'restcategorie' van de overige dienstverlenende functies. Het CBS heeft ondermeer de beroepsgroep van dokters-, tandarts- en dierenartsassistenten aan deze diverse beroepsklasse toegevoegd. Mannen daarentegen zijn in een groot scala van 'overige' dienstverlenende functies te vinden.

45. Indien meer dan $10 \%$ van de mannelijke of vrouwelijke beroepsbeoefenaren in een 'vrouwenberoep' een bepaald opleidingstype als hoogst genoten opleidingsachtergrond heeft, dan wordt deze opleiding in dit schema vermeld. De opleidingen worden in volgorde van belangrijkheid aangegeven.

46. Bijvoorbeeld een confectie-opleiding in het leerlingwezen. Deze opleidingen worden in de SOI overigens aangemerkt als technische opleiding. Dit verklaart mede het hoge percentage vrouwen in de beroepsklasse confectiemakers \& stoffeerders, dat een 'technische' opleidingsachtergrond heeft. 
Op de tweede plaats kunnen de verschillen tussen beide sexen voor wat betreft de opleidingsachtergrond in overeenkomstige vrouwenberoepen het gevolg zijn van de branche waarin beide sexen een bepaald beroep uitoefenen. lets dergelijks lijkt bijvoorbeeld op te gaan voor de beroepsklasse van telefonisten en telegrafisten. Mannen werken waarschijnlijk vaker als telefonist, indien dit beroep gekoppeld is aan een soort 'bewakingsfunctie'. Een belangrijk deel van de mannelijke telefonisten heeft namelijk, in tegenstelling tot de vrouwelijke telefonisten, een middelbare bewakingsopleiding gevolgd.

Ten derde kunnen ook verschillen tussen beide sexen qua functieniveau een rol spelen bij de verklaring van hun verschillen in opleidingsachtergrond. In de beroepsklasse van winkelbedienden hebben mannen bijvoorbeeld vaker een middelbare economisch en/of administratieve opleiding (MEAO/MMO) gevolgd dan de vrouwelijke winkelbedienden, waarbij juist het aandeel met een verzorgende of algemene opleiding relatief groot is. Dit kan er op duiden dat mannen binnen de omvangrijke categorie van winkelbedienden vaker een hogere functie of specialistische bezetten. lets dergelijks kan eveneens bij de beroepsklasse van telefonisten en telegrafisten het geval zijn. Bij de mannelijke telefonisten is namelijk de HBOopleiding voor Verkeer, Vervoer en Telecommunicatie de belangrijkste opleidingsachtergrond.

Omgekeerd blijkt van de vrouwelijke secretaressen maar liefst $15 \%$ een economischadministratieve opleiding op HBO-niveau genoten te hebben. Van de mannelijke secretarieel medewerkers heeft slechts $6 \%$ een dergelijke opleidingsachtergrond. Analoog aan bovenstaande verklaring bij de beroepsklassen van winkelbedienden en telefonisten is het wellicht zo, dat de secretaressen van het vrouwelijke geslacht zijn oververtegenwoordigd in de hogere secretaressebanen (bijvoorbeeld die van directie-secretaressen).

De verschillen tussen beide sexen naar opleidingsachtergrond kunnen soms ook zeer subtiel, maar daarom nog niet van minder belang zijn. Zo lijken de opleidingsachtergronden van mannen en vrouwen in de beroepsklasse van kappers en schoonheidsspecialisten vrijwel identiek. Wanneer men zich echter realiseert, dat mannen relatief vaker de kappersopleidingen volgen waarmee men een bevoegdheid kan behalen om zich zelfstandig te vestigen en vrouwen relatief vaker de opleidingen waarmee deze bevoegdheid niet kan worden behaald, dan blijken de opleidingsachtergronden van beide sexen in deze beroepsklasse toch weer een belangrijke discrepantie te bevatten (zie hiervoor ook de verschillen tussen beide sexen in zelfstandig ondernemerschap).

Tenslotte valt op, dat een groot gedeelte van de beroepsbeoefenaren in de vrouwenberoepen, namelijk gemiddeld éénderde, vaak een algemene opleidingskwalificatie heeft. Mannen blijken overigens iets vaker een algemene opleidingskwalificatie te hebben dan vrouwen in deze beroepsklassen: gemiddeld 36 versus 32 procent. Daarentegen hebben de vrouwen in deze vrouwenberoepen dikwijls een opleiding in de verzorgende sfeer achter de rug, terwijl mannen ook vaak met een technische opleidingsachtergrond in één van de verzorgende vrouwenberoepen zijn vertegenwoordigd. Dit duidt erop dat voor de onderscheiden vrouwenberoepen dus in veel gevallen geen beroepsspecifieke opleidingskwalificaties van de 
$-41-$

(mannelijke) beroepsbeoefenaren worden verlangd (met uitzondering van de verpleeg- en geneeskundigen, de kappers en schoonheidsspecialisten, doktersassistenten en confectiemakers).

\subsection{Actuele arbeidsmarktkenmerken vrouwenberoepen}

In deze paragraaf is een aantal actuele arbeidsmarktkenmerken van de geselecteerde vrouwenberoepen samengevat. De hierbij gepresenteerde kengetallen en trends zullen bovendien worden voorzien van zogenaamde typeringen, waarbij de arbeidsmarktpositie van de vrouwenberoepen wordt vergeleken met die van alle beroepen tezamen ${ }^{47}$.

Tabel 26. Het gewogen functieniveau in 1985 en rangnummer prestigescore in 1982 per vrouwenberoep

\begin{tabular}{|c|c|c|c|c|c|}
\hline \multirow[b]{2}{*}{ Code } & \multirow[b]{2}{*}{ Beroepsklasse } & \multicolumn{2}{|c|}{ Gewogen Functieniveau } & \multicolumn{2}{|c|}{ Beroepsprestige } \\
\hline & & score & typering & rangnummer & typering \\
\hline $6 / 7$ & Verpleeg- en geneeskundigen & 5,0 & hoog & $34^{48}$ & hoog \\
\hline 32 & Secretaressen, typisten & 3,6 & gemiddeld & 45 & gemiddeld \\
\hline 38 & Telefonisten, telegrafisten & 3,1 & laag & 66 & laag \\
\hline 48 & Winkelbedienden e.a. verkopers & 2,1 & laag & 84 & zeer laag \\
\hline 54 & Verzorgend en huishoudelijk personeel & 2,8 & laag & 78 & zeer laag \\
\hline 55 & Schoonmakers, conciërges & 1,3 & zeer laag & 90 & zeer laag \\
\hline 56 & Wasserijpersoneel & 1,1 & zeer laag & 91 & zeer laag \\
\hline 57 & Kappers, schoonheidsspecialisten & 3,8 & gemiddeld & 52 & gemiddeld \\
\hline 59 & Dienstverlenende functies n.e.g. & 3,0 & gemiddeld & 51 & gemiddeld \\
\hline 79 & Confectiemakers, stoffeerders & 2,2 & laag & 68 & laag \\
\hline \multirow{2}{*}{\multicolumn{2}{|c|}{$\begin{array}{l}\text { Gemiddelde vrouwenberoepen } \\
\text { Gemiddelde alle beroepsklassen }\end{array}$}} & 2,8 & laag & 66 & laag \\
\hline & & 3,7 & gemiddeld & 46 & gemiddeld \\
\hline
\end{tabular}

Bron: ROA/Huijgen/Sixma \& Ultee

Allereerst is het functieniveau ${ }^{49}$ van deze vrouwenberoepen bepaald, waarbij de mate van

47. Voor de grenzenindeling van de typeringen van de kengetallen en trends wordt verwezen naar het werkdocument van Wieling, de Grip en Willems (1990). Wieling e.a. hebben daarbij geprobeerd tot eem meer systematische onderbouwing te komen van de diverse kwalitatieve typeringen, waarbij het uitgangspunt was dat de typering een beeld geeft van de relatieve positionering van een beroepsklasse of opleidingstype ten opzichte van de overige beroepsklassen of opleidingstypen.

48. Het gaat hier om het rangnummer van de beroepsprestige voor de CBS-beroepsgroepen (3e digit) 640 en 680-0798; m.a.w. om de verpleegkundigen, fysiotherapeuten, mondhygiënisten e.d. Artsen, tandartsen e.d. hebben als rangnummer 4.

49. Voor het bepalen van het functieniveau is gebruik gemaakt van de score die Huijgen op basis van de ARBVO-beroepenclassificatie aan de CBS-beroepen (4e digit) heeft toegekend. De laagst mogelijke score bedraagt 1 , de hoogste 7 . Voor het bepalen van het functieniveau per CBS-beroepsklasse (2e digit) is het gewogen gemiddelde berekend. 
ingewikkeldheid van de werkzaamheden in het betreffende beroep het functieniveau bepaalt (zie tabel 26). vrouwenberoepen blijken gemiddeld een lager functieniveau te hebben. Niet alleen het gemiddelde over de vrouwenberoepen is lager dan het gemiddelde over alle beroepsklassen, maar ook de vrouwenberoepen met een hoog functieniveau zijn zwaar ondervertegenwoordigd. Terwijl van alle beroepsklassen $45 \%$ een score behaalt van 4 of hoger, heeft van de vrouwenberoepen slechts de (heterogene) klasse van verpleeg- en geneeskundigen ${ }^{50}$ een dergelijke score behaald. De vrouwenberoepen zijn met name in de klasse van de gemiddelde score van 3 tot 4 oververtegenwoordigd (40\% van de vrouwenberoepen versus $15 \%$ van alle beroepsklassen).

Naast het functieniveau is eveneens gekeken naar het 'maatschappelijk aanzien' van de vrouwenberoepen. Een vijfhonderdtal respondenten heeft aan de hand van de volgende aspecten de beroepsprestige voor 116 (representatieve) beroepen bepaald: maatschappelijk en eigen (oordeel over) aanzien, inkomen, algemene en persoonlijke aantrekkelijkheid, kennis, verantwoording en vuil of schoon werk. Deze beroepsprestigeladder is door Sixma en Ultee (1983) vervolgens versleuteld naar CBS-beroepsklassen, waarbij sommige klassen zijn gesplitst, zodat 92 klassen worden onderscheiden (exclusief beroepsmilitairen). De genoemde typeringen zijn bepaald aan de hand van de rangnummers van de score met betrekking tot het aanzien van de CBS-beroepsklassen, waarbij vijf klassen zijn geconstrueerd (van een zeer laag tot een zeer hoog rangnummer). Zoals uit tabel 26 is af te lezen, behoort alleen de beroepsklasse van verpleeg- en geneeskundigen tot de beroepsklassen met een 'hoog tot zeer hoog aanzien'. Hierbij geldt, dat de (voornamelijk mannelijke) beroepsgroep van geneeskundigen een zeer hoog maatschappelijk aanzien heeft, terwijl de (overwegend vrouwelijke) verpleegkundigen e.a. paramedici een hoge beroepsprestige hebben. De overige vrouwenberoepen hebben wat betreft de score op het kenmerk 'maatschappelijk aanzien' rangordenummers tussen de 45 en 91; dat wil zeggen dat de vrouwenberoepen een zeer lage tot hooguit gemiddelde beroepsprestige kennen.

Het is juist opvallend, dat het maatschappelijk aanzien van de vrouwenberoepen even laag en soms zelfs nog lager blijkt te zijn dan het functieniveau, dat een (redelijk) objectieve maatstaf is voor de complexiteit van de werkzaamheden in een bepaald beroep ${ }^{51}$. De status (evenals het inkomen) van vrouwenberoepen is dus vaak nog lager dan op grond van de complexiteit van de werkzaamheden kan worden verwacht (zie tabel 26).

50. Terwijl de geneeskundigen wat betreft functieniveau een score van 7 behalen, scoren de gediplomeerde en leerling-verpleegkundigen hierop respectievelijk een 5.2. en 3.8.

51. Dit geldt zeker niet voor alle beroepsklassen. Voor met name een aantal typische 'mannenberoepen' geldt namelijk het omgekeerde. Het aanzien van deze beroepen, vooral degenen die orde en veiligheid betreffen, evenals een aantal (vermeend) zware (industriële) beroepen, is namelijk hoger, dan op grond van hun functieniveau kan worden verwacht. 
Tabel 27. Aandeel en trend deeltijders in de periode 1979-1985 per vrouwenberoep in procenten

\begin{tabular}{|c|c|c|c|c|}
\hline \multirow[b]{2}{*}{ Code } & \multirow[b]{2}{*}{ Beroepsklasse } & \multirow[b]{2}{*}{$\%$} & \multicolumn{2}{|l|}{ Deeltijders } \\
\hline & & & typering & trend \\
\hline $6 / 7$ & Verpleeg-en geneeskundigen & 27 & gemiddeld & sterk stijgend \\
\hline 32 & Secretaressen, typisten & 33 & hoog & sterk stijgend \\
\hline 38 & Telefonisten, telegrafisten & 39 & hoog & sterk stijgend \\
\hline 48 & Winkelbedienden e.a. verkopers & 39 & hoog & sterk stijgend \\
\hline 54 & Verzorgend en huishoudelijk personeel & 68 & zeer hoog & stijgend \\
\hline 55 & Schoonmakers, conciërges & 70 & zeer hoog & stijgend \\
\hline 56 & Wasserijpersoneel & 26 & gemiddeld & sterk stijgend \\
\hline 57 & Kappers, schoonheidsspecialisten & 37 & hoog & sterk stijgend \\
\hline 59 & Dienstverlenende functies n.e.g. & 31 & hoog & sterk stijgend \\
\hline 79 & Confectiemakers, stoffeerders & 31 & hoog & sterk stijgend \\
\hline \multirow{2}{*}{\multicolumn{2}{|c|}{$\begin{array}{l}\text { Gewogen gemiddelde vrouwenberoepen } \\
\text { Gewogen gemiddelde alle beroepsklassen }\end{array}$}} & 43 & hoog & sterk stijgend \\
\hline & & 20 & gemiddeld & sterk stijgend \\
\hline
\end{tabular}

Bron: CBS/ROA

Conform de verwachtingen is het aandeel deeltijders ${ }^{52}$ gemiddeld hoog in de vrouwenberoepen (zie tabel 27). Een hoog tot zeer hoog aandeel deeltijders is zelfs te vinden in acht van de tien vrouwenberoepen. In geen enkel vrouwenberoep komt een laag percentage deeltijders voor. Ook in de vrouwenberoepen is het aandeel deeltijders tussen 1979 en 1985 sterk toegenomen, hoewel deze een lager groeitempo hebben dan alle beroepsklassen tezamen (toename van 27\% versus $39 \%$ ). Waarschijnlijk speelt verzadiging hierbij een rol; deze verklaring sluit aan bij het feit, dat bij de twee vrouwenberoepen met het hoogste percentage deeltijders de toename geringer was dan in het algemeen.

Hoewel het aandeel zelfstandig over het algemeen zo wie zo laag is te noemen, is het aandeel van zelfstandigen in de vrouwenberoepen nog niet de helft van het aandeel gemeten over alle beroepsklassen tezamen (zie tabel 28). Alleen de beroepsklasse van kappers en schoonheidsspecialisten bevat relatief veel zelfstandig ondernemers ${ }^{53}$. Hoewel er onmiskenbaar een verband is tussen sexe en beroep, lijkt het feit dat het aandeel van zelfstandigen in de vrouwenberoepen zo laag is, echter minder met de aard van het beroep of de branche te maken te hebben, maar meer met de sexe van de beroepsbeoefenaren (zie ook voetnoot 55 en paragraaf 5.2.).

52. Het gaat hierbij om het percentage werkzame personen, dat in de periode 1979-1985 een werkweek van minder dan 35 uur had. De grenzen voor de typering van het aandeel en de trend zijn aan deze urengrens aangepast (zie ook Wieling e.a., 1990).

53. Binnen deze beroepsklasse zijn de mannelijke beroepsbeoefenaren echter relatief vaker als zelfstandige werkzaam dan de vrouwen. Van de mannen in deze beroepsklasse werkt namelijk $40 \%$ in loondienst, terwijl van de vrouwen $63 \%$ in loondienst werkzaam is (AKT 1985). 
Tabel 28. Aandeel en trend zelfstandigen in de periode 1979-1985 per vrouwenberoep in procenten

\begin{tabular}{|c|c|c|c|c|}
\hline \multirow[b]{2}{*}{ Code } & \multirow[b]{2}{*}{ Beroepsklasse } & \multirow[b]{2}{*}{$\%$} & \multicolumn{2}{|c|}{ Zelfstandigen } \\
\hline & & & typering & trend \\
\hline $6 / 7$ & Verpleeg- en geneeskundigen & 12 & gemiddeld & stijgend \\
\hline 32 & Secretaressen, typisten & 0 & zeer laag & constant \\
\hline 38 & Telefonisten, telegrafisten & 0 & zeer laag & constant \\
\hline 48 & Winkelbedienden e.a. verkopers & 0 & zeer laag & constant \\
\hline 54 & Verzorgend en huishoudelijk personeel & 0 & zeer laag & constant \\
\hline 55 & Schoonmakers, conciërges & 2 & laag & dalend \\
\hline 56 & Wasserijpersoneel & 11 & gemiddeld & dalend \\
\hline 57 & Kappers, schoonheidsspecialisten & 41 & hoog & constant \\
\hline 59 & Dienstverlenende functies n.e.g. & 0 & zeer laag & constant \\
\hline 79 & Confectiemakers, stoffeerders & 19 & gemiddeld & sterk dalend \\
\hline \multirow{2}{*}{\multicolumn{2}{|c|}{$\begin{array}{l}\text { Gewogen gemiddelde vrouwenberoepen } \\
\text { Gewogen gemiddelde alle beroepsklassen }\end{array}$}} & 4 & laag & licht dalend \\
\hline & & 9 & $\operatorname{laag}^{54}$ & dalend \\
\hline
\end{tabular}

Bron: CBS/ROA

Tabel 29. Branchespreiding in de periode 1979-1985 per vrouwenberoep

Branchespreiding

Code Beroepsklasse score typering trend

\begin{tabular}{|c|c|c|c|c|}
\hline $6 / 7$ & Verpleeg- en geneeskundigen & 0,3 & klein & constant \\
\hline 32 & Secretaressen, typisten & 0,9 & zeer groot & constant \\
\hline 38 & Telefonisten, telegrafisten & 0,9 & zeer groot & constant \\
\hline 48 & Winkelbedienden e.a. verkopers & 0,3 & klein & constant \\
\hline 54 & Verzorgend en huishoudelijk personeel & 0,4 & gemiddeld & sterk dalend \\
\hline 55 & Schoonmakers, conciërges & 0,8 & groot & constant \\
\hline 56 & Wasserijpersoneel & 0,4 & gemiddeld & sterk dalend \\
\hline 57 & Kappers, schoonheidsspecialisten & 0,1 & zeer klein & sterk stijgend \\
\hline 59 & Dienstverlenende functies n.e.g. & 0,7 & groot & dalend \\
\hline 79 & Confectiemakers, stoffeerders & 0,7 & groot & constant \\
\hline \multirow{2}{*}{\multicolumn{2}{|c|}{$\begin{array}{l}\text { Gemiddelde vrouwenberoepen } \\
\text { Gemiddelde alle beroepsklassen }\end{array}$}} & 0,6 & gemiddeld & constant \\
\hline & & 0,5 & gemiddeld & constant \\
\hline
\end{tabular}

Bron: CBS/ROA

De arbeidsmarktpositie van de beroepsbeoefenaren in vrouwenberoepen wordt vervolgens

54. Doordat de zelfstandig werkenden slechts in een beperkt aantal beroepsklassen zijn geconcentreerd, terwijl voor een groot aantal beroepsklassen het percentage zelfstandigen (vrijwel) gelijk is aan 0 is hiervoor ad hoc een indeling gekozen, met als resultaat dat het gewogen gemiddelde over alle beroepsklassen als relatief laag wordt getypeerd (zie ook Wieling e.a., 1990). 
belicht aan de hand van een aantal kenmerken van de branches waarin deze vrouwenberoepen zijn vertegenwoordigd. De vraag is in hoeverre de branchestructuur van deze vrouwenberoepen als een risicofactor voor de arbeidsmarktpositie kan worden beschouwd. Achtereenvolgens zullen voor de vrouwenberoepen de uitwijkmogelijkheden naar diverse branches, evenals de gevoeligheid voor conjunctuurschommelingen de revue passeren ${ }^{55}$.

Dikwijls wordt beweerd, dat de zwakke arbeidsmarktpositie van vrouwen deels tot uiting komt in (en het gevolg is van) het feit, dat vrouwen in slechts enkele (dienstverlenende) branches zijn geconcentreerd. Hierdoor zouden vrouwen relatief een groter risico lopen op bijvoorbeeld werkloosheid, als het deze branches economisch minder goed gaat. Wanneer men werkzaam is in een beroep dat uitwijkmogelijkheden heeft naar een groot scala van branches, kan men dit risico dus reduceren. Het ROA heeft voor alle beroepsklassen (CBS, 2-digit) deze branchespreiding berekend. Hierbij geeft een lage branchespreiding aan dat in een beroepsklasse slechts werkenden uit één (de coëfficiënt is dan 0) of enkele branches voorkomen. Een hoge branchespreiding duidt op een gelijkmatige verdeling van de branches in een bepaalde beroepsklasse. In tegenspraak met de verwachting blijken slechts drie van de tien vrouwenberoepen een (zeer) kleine branchespreiding te hebben ${ }^{56}$. De vrouwenberoepen blijken zelfs een iets groter dan gemiddelde branchespreiding te hebben. Tussen de vrouwenberoepen onderling komen in de branchespreiding echter wel grote verschillen voor. Zo hebben de beroepsklassen van de secretaressen en typisten, evenals van de telefonisten, die beide behoren tot de zogenaamde procesgebonden beroepen ${ }^{57}$, een zeer grote branchespreiding. Daarentegen hebben de kappers en schoonheidsspecialisten zeer weinig uitwijkmogelijkheden naar andere branches $^{58}$.

55. In De Grip, Heijke en Dekker (1989) wordt uitgebreid ingegaan op de wijze waarop de branchespreiding en de conjunctuurgevoeligheid is berekend.

56. De branchespreidingscoëfficiënten zijn mede afhankelijk van het aggregatieniveau en de homogeniteit van de onderscheiden beroepen en branches (zie ook Dekker e.a., 1990). Juist omdat in de gebruikte bedrijfssectorindeling de industriële sector, waarin 'mannenberoepen' zijn oververtegenwoordigd, verder is onderverdeeld dan de agrarische en dienstverlenende sector, waarin vrouwen meer voorkomen, is deze gemiddelde tot grote branchespreiding voor alle 'vrouwenberoepen' tezamen des te opvallender.

57. Daarentegen zijn de zogenaamde produktgebonden beroepen veel vaker aan een bepaalde branche verbonden (Zie Ministerie van Sociale Zaken en Werkgelegenheid, 1990, blz. 58).

58. Hierbij dienen we ons wel te realiseren, dat de resultaten m.b.t. de branchespreiding mede worden beïnvloed door de grote mate van samenhang tussen de gehanteerde beroepsklassen- en bedrijfssectorindeling. 


\section{Conjunctuurgevoeligheid}

\section{Code Beroepsklasse}

score

typering

6/7 Verpleeg-en geneeskundigen

32 Secretaressen, typisten

38 Telefonisten, telegrafisten

48 Winkelbedienden e.a. verkopers

54 Verzorgend en huishoudelijk personeel

55 Schoonmakers, conciërges

56 Wasserijpersoneel

57 Kappers, schoonheidsspecialisten

59 Dienstverlenende functies n.e.g.

79 Confectiemakers, stoffeerders

\section{1,65}

1,58

1,47

1,46

1,52

1,38

1,53

1,32

1,63

3,12

1,66

1,75 gemiddeld

gemiddeld

gemiddeld gemiddeld gemiddeld

klein gemiddeld

klein gemiddeld zeer groot

gemiddeld gemiddeld

\section{Bron: CBS/ROA}

Daarnaast is voor de vrouwenberoepen nagegaan of zij zijn oververtegenwoordigd in de branches die conjunctuurgevoelig zijn. Hierbij wordt de trendmatige werkgelegenheidsontwikkeling van de branches waarin de betreffende beroepsklassen zijn vertegenwoordigd afgezet tegen de totale conjunctuurschommelingen in het verleden. Afgezien van de zeer conjunctuurgevoelige beroepsklasse van confectiemakers en stoffeerders, blijken de vrouwenberoepen meestal een gemiddelde en soms zelfs een lage conjunctuurgevoeligheid te hebben. Vrouwenberoepen zijn dus niet gevoeliger voor conjunctuurschommelingen, dan alle onderscheiden beroepsklassen tezamen.

\subsection{Arbeidsmarktperspectieven vrouwenberoepen}

Tot nu toe is een aantal actuele kenmerken van vrouwenberoepen besproken. Hierna zullen de arbeidsmarktperspectieven voor de nabije toekomst voor deze beroepen worden geschetst. Dit arbeidsmarktperspectief zal worden uitgedrukt in het percentage 'job-openings' dat gedurende de prognoseperiode 1989-1994 ten opzichte van het basisjaar 1989 zal ontstaan. 'Jobopenings' (te vervullen banen) zijn het gevolg van enerzijds een toenemende werkgelegenheid (uitbreidingsvraag) en anderzijds vervangingsvraag ${ }^{59}$.

59. Zie voor een uitgebreide beschrijving van de wijzen waarop de uitbreidings- en vervangingsvraag zijn berekend respectievelijk De Grip e.a. (1989) en Willems e.a. (1990). 
$-47-$

Tabel 31. Procentuele groei van de uitbreidings-, vervangings- en totale vraag in de periode 1989-1994 per vrouwenberoep

\begin{tabular}{|c|c|c|c|c|c|c|c|}
\hline \multirow[b]{2}{*}{ Code } & \multirow[b]{2}{*}{ Beroepsklasse } & \multicolumn{2}{|c|}{ Uitbreidingsvraag } & \multicolumn{2}{|c|}{ Vervangingsvraag } & \multicolumn{2}{|c|}{ Totale vraag } \\
\hline & & $\%$ & typering & $\%$ & typering & $\%$ & typering \\
\hline $6 / 7$ & Verpleeg- en geneeskundigen & 7 & gemiddeld & 8 & laag & 16 & gemiddeld \\
\hline 32 & Secretaressen, typisten & 3 & gemiddeld & 19 & hoog & 22 & hoog \\
\hline 38 & Telefonisten, telegrafisten & -23 & zeer laag & 16 & hoog & 16 & gemiddeld \\
\hline 48 & Winkelbedienden e.a. verkopers & 10 & hoog & 24 & zeer hoog & 34 & zeer hoog \\
\hline 54 & Verzorgend en huishoudelijk & & & & & & \\
\hline & personeel & 5 & gemiddeld & 14 & gemiddeld & 19 & gemiddeld \\
\hline 55 & Schoonmakers, conciërges & 4 & gemiddeld & 11 & gemiddeld & 15 & gemiddeld \\
\hline 56 & Wasserijpersoneel & 5 & gemiddeld & 21 & zeer hoog & 25 & hoog \\
\hline 57 & Kappers, schoonheidsspecialisten & 5 & gemiddeld & 15 & gemiddeld & 20 & gemiddeld \\
\hline 59 & Dienstverlenende functies n.e.g. & 6 & gemiddeld & 16 & hoog & 22 & hoog \\
\hline 79 & Confectiemakers, stoffeerders & 1 & gemiddeld & 9 & laag & 10 & laag \\
\hline Gemic & delde vrouwenberoepen & $5^{60}$ & gemiddeld & 15 & gemiddeld & 20 & gemiddeld \\
\hline Gemic & delde alle beroepsklassen & 6 & gemiddeld & 12 & gemiddeld & 18 & gemiddeld \\
\hline
\end{tabular}

Bron: CBS/ROA

De som van de uitbreidingsvraag en de vervangingsvraag resulteert bij de vrouwenberoepen in het algemeen in een gemiddelde tot hoge totale vraag. Bij de vrouwenberoepen speelt vooral de vervangingsvraag, meer dan bij de andere beroepsklassen, een belangrijke rol. De uitbreidingsvraag is daarentegen in de meeste gevallen gemiddeld. De werkgelegenheid in vrouwenberoepen zal de komende jaren dus niet beter of slechter zijn dan die in alle beroepsklassen tezamen. Zoals reeds in paragraaf 4.2. is geconstateerd blijkt de beroepsklasse van telefonisten echter een 'krimpberoep' te worden, terwijl die van winkelpersoneel omgekeerd tot de 'groeiberoepen' zal gaan behoren. Afgezien van de twee naar sexe heterogene beroepsklassen van genees- en verpleegkundigen en confectiemakers en stoffeerders, is de vervangingsvraag onder de vrouwenberoepen gemiddeld tot (zeer) hoog. In deze vaak hoge vervangingsvraag weerspiegelt zich dus het participatiepatroon van vrouwen. Nadat vrouwen een aantal jaren (in een vrouwenberoep) werkzaam zijn geweest, verlaten velen onder hen voor enkele jaren - de arbeidsmarkt om de taken 'binnenshuis' op zich te nemen.

60. Dit is exclusief de nogal kleine klasse van telefonisten e.d., welke in de prognoseperiode zeer sterk zal afnemen (namelijk met $23 \%$ ). Inclusief deze beroepsklasse bedraagt het gemiddelde bij de 'vrouwenberoepsklassen' slechts $2,3 \%$, hetgeen overigens nog steeds als gemiddeld getypeerd kan worden. 


\section{ARBEIDSMARKTKARAKTERISTIEKEN VROUWENOPLEIDINGEN}

\subsection{Inleiding}

Analoog aan de bespreking van de zogenaamde vrouwenberoepen zal in dit hoofdstuk een aantal arbeidsmarktkenmerken van een tiental typisch 'vrouwelijke' opleidingstypen worden besproken. Met behulp van de Arbeidskrachtentelling (AKT) van het CBS is nagegaan welke opleidingsachtergrond de werkenden als hoogste onderwijskwalificatie hebben. Net als bij de vrouwenberoepen zullen niet de arbeidsmarktdimensies van deze opleidingstypen zelf worden beschreven, doch de karakteristieken van degenen die met een bepaalde opleidingsachtergrond werkzaam zijn. In dit kader gaat het dan om typisch 'vrouwelijke' opleidingskwalificaties. De tien opleidingstypen ${ }^{61}$ met het hoogste aandeel vrouwen in 1985 zullen in dit werkdocument als vrouwenopleidingen worden aangemerkt (zie tabel 32).

Tabel 32. Werkzame vrouwen met 'vrouwenopleidingstypen' ${ }^{62}$ als opleidingsachtergrond in 1979 en 1985, absoluut ( $x$ 1000; afgerond) en in procenten

\begin{tabular}{|c|c|c|c|c|c|c|c|}
\hline \multirow[b]{2}{*}{ Code } & \multirow[b]{2}{*}{ Opleidingstype } & \multicolumn{2}{|c|}{ absoluut } & \multicolumn{2}{|c|}{$\%$ vrouw } & \multirow{2}{*}{$\begin{array}{l}\% \text { in } \\
\text { vroun } \\
79\end{array}$} & \multirow{2}{*}{$\begin{array}{l}\text { totaa } \\
' 85\end{array}$} \\
\hline & & $' 79$ & $' 85$ & $' 79$ & $' 85$ & & \\
\hline 7 & LBO Econ.-Administratief & 66 & 86 & 33 & 60 & 5 & 5 \\
\hline 8 & LBO Soc. Verzorging \& Horeca & 202 & 211 & 89 & 89 & 15 & 13 \\
\hline 16 & MBO Verpleging & 61 & 83 & 83 & 85 & 4 & 5 \\
\hline 17 & MBO Medisch Laboratorium & 11 & 15 & 72 & 72 & 1 & 1 \\
\hline 18 & MBO Ziekenverzorging & 19 & 34 & 93 & 91 & 1 & 2 \\
\hline 22 & MBO Sociale Verzorging & 87 & 133 & 94 & 92 & 6 & 8 \\
\hline 33 & HBO Verpleging \& Therapie & 16 & 31 & 68 & 67 & 1 & 2 \\
\hline 34 & HBO Medisch Laboratorium & 6 & 12 & 79 & 70 & 0 & 1 \\
\hline 35 & HBO Diëtetiek & 1 & 2 & 95 & 87 & 0 & 0 \\
\hline \multirow{3}{*}{\multicolumn{2}{|c|}{$\begin{array}{l}\text { absoluut aantal vrouwen met vrouwenopleiding } \\
\% \text { vrouwen in totaal werkzame personen } \\
\text { Gemiddeld \% vrouwen per vrouwenopleiding }\end{array}$}} & 499 & 631 & & & & \\
\hline & & & & 29 & 34 & & \\
\hline & & & & 80 & 78 & & \\
\hline \multicolumn{4}{|c|}{ Som \% vrouwenopleidingen in totaal werkzame vrouwen } & & & 35 & 38 \\
\hline
\end{tabular}

Bron: CBS/ROA

In de periode 1979-1985 is het percentage werkende vrouwen met een 'vrouwelijke'

61. Het gaat hier om de ROA-opleidingstypen die het ROA in 1990 heeft gehanteerd en die zijn gebaseerd op het 3 e digitniveau van de Standaard Onderwijs Indeling (SOI) van het CBS.

62. De opleiding MBO pedagogiek wordt niet tot de vrouwenopleidingen gerekend, aangezien de opleiding tot kleuterleider (KLOS), die voorheen tot deze categorie behoorde, is opgeheven en de resterende opleidingen uit dit cluster (bijvoorbeeld opleiding tot rijinstructeur) geen typische vrouwenopleidingen zijn. 
opleidingsachtergrond in de totale werkgelegenheid van vrouwen licht gestegen; namelijk van 35 naar 38 procent. In diezelfde periode is het gemiddelde percentage van vrouwen met een 'vrouwelijke' opleidingsachtergrond ten opzichte van alle beroepsbeoefenaren met een dergelijke onderwijskwalificatie echter licht gedaald. In 1979 bedroeg dit percentage namelijk nog 80\%, terwijl in 1985 de man-/vrouwverhouding gemiddeld over alle 'vrouwenopleidingstypen' $78 \%$ was. Deze min of meer tegengestelde ontwikkeling was mogelijk, doordat het percentage vrouwen in het totaal van de werkzame personen in de periode 1979-1985 is gestegen van $29 \%$ naar $34 \%$.

Absoluut gezien is de werkgelegenheid voor vrouwen met een 'vrouwelijke' opleidingsachtergrond sterk toegenomen: van bijna 500.000 naar ruim 600.000 werkende vrouwen. Deze absolute toename geldt voor alle vrouwenopleidingen. Het aandeel van de werkende vrouwen met LBO Sociale Verzorging en Horeca (voornamelijk LHNO) als opleidingskwalificatie is echter wel in de totale werkgelegenheid van vrouwen gedaald. Dit is het gevolg van het feit dat vanaf het begin van de jaren tachtig de instroom op de arbeidsmarkt van gediplomeerde LBO-ers in het algemeen en van LHNO-ers in het bijzonder sterk is gedaald. Zoals reeds is aangegeven bij de onderwijsontwikkelingen is in de jaren tachtig het aandeel van het LBO in de totale uitstroom naar de arbeidsmarkt gehalveerd.

De man-/vrouwverhouding in het aantal werkenden heeft zich bij de onderscheiden vrouwenopleidingen nogal verschillend ontwikkeld. Bij een zestal vrouwenopleidingen is deze verhouding min of meer constant gebleven; dat wil zeggen niet meer dan $5 \%$ gewijzigd. Bij een tweetal vrouwenopleidingen is het percentage vrouwen echter aanzienlijk gedaald. Zo neemt het aandeel van mannen in de uitstroom van de HBO-opleidingstypen Diëtetiek en Medisch Laboratorium dermate snel toe, dat de man-/vrouwverhouding bij de werkenden met deze opleidingskwalificaties in korte tijd aanzienlijk is veranderd ten gunste van mannen. Omgekeerd is op het LBO-niveau het Economisch \& Administratieve onderwijs in de periode 1979-1985 steeds meer een typisch 'vrouwelijke' onderwijskwalificatie geworden. Enerzijds komt dat doordat vrouwen, sterker dan mannen, met deze onderwijskwalificatie de arbeidsmarkt hebben betreden. Anderzijds hebben vooral mannen met deze onderwijskwalificatie de arbeidsmarkt aan het begin van de jaren tachtig verlaten.

\subsection{Beroepsprofiel vrouwenopleidingen}

In bijlage 2 is een overzicht opgenomen van de belangrijkste beroepsklassen (CBS, 2e digitniveau) waarin de mannen en vrouwen die een vrouwenopleiding als hoogste onderwijskwalificatie hebben genoten in 1985 werkzaam zijn. Uit dit overzicht blijkt, evenals uit paragraaf 3.3. over beroepssegregatie, dat, ook als mannen en vrouwen eenzelfde opleidingsachtergrond hebben, zij in verschillende beroepen terecht komen. Voor deze constatering is een aantal redenen aan te voeren.

Ten eerste bevatten de onderscheiden opleidingstypen af en toe een te heterogene verzameling van opleidingen. Dit geldt bijvoorbeeld voor de beroepsbeoefenaren die LBO Sociale Verzorging 
\& Horeca als opleidingskwalificatie hebben. Volgens de SOI behoort namelijk ook de LTSopleiding Kok/Kelner tot dit opleidingstype. Terwijl van de vrouwen met dit opleidingstype de meesten het LHNO of de huishoudschool hebben gevolgd, hebben van de mannen daarentegen relatief veel de LTS-opleiding Kok/Kelner gevolgd. Deze verschillen in opleidingskwalificatie kan men dan ook terugvinden in de beroepen van de mannen en vrouwen met de opleidingskwalificatie LBO Sociale Verzorging \& Horeca.

Ook bij het opleidingstype MBO Medisch Laboratorium speelt de heterogeniteit van de opleidingsvariabele een rol. Immers een aantal opleidingen in het leerlingwezen die het vervaardigen van medisch instrumentarium of het beroep van opticien betreffen, is in de SOI ondergebracht bij het middelbare medisch laboratoriumonderwijs. Het zijn vooral mannen die deze opleidingen volgen, hetgeen gereflecteerd wordt in het feit, dat bijna éen op de vijf mannen met MBO Medisch Laboratorium als opleidingskwalificatie instrumentmaker, c.q. machinebankwerker-monteur dan wel als opticien zelfstandig winkelier is.

Verder is het opvallend dat mannen met een middelbare verplegende of verzorgende opleidingskwalificatie bijna allemaal terechtkomen in de intramurale verpleegkundige functies, terwijl van de vrouwen met een dergelijke opleidingskwalificatie een aanzienlijk deel als extramurale bejaarden-, kinder- of gezinsverzorger werkzaam is. De intramurale verpleegkundigen hebben niet alleen een beter inkomen en een beter carrièreperspectief, maar ook een veel hogere status dan de extramurale verzorgers (rangordenummer 35 versus 78 van de 92 onderscheiden beroepsklassen). In de afbakening van zogenaamde 'cure' en 'care' taken lijkt de beeldvorming over mannen en vrouwen aldus een belangrijke rol te spelen (zie ook Brouns en Schokker, blz. 187-188).

Daarnaast blijkt nog een aantal beroepen op de arbeidsmarkt typisch 'vrouwelijk' of 'mannelijk'. Zo is van de vrouwen met een kwalificatie LBO Economisch \& Administratief maar liefst $17 \%$ secretaresse of typiste, maar vervult van de mannen met deze kwalificatie slechts $0,6 \%$ een dergelijke functie. Dit terwijl mannen en vrouwen met deze opleidingskwalificatie voor de rest in dezelfde beroepensklassen (in ongeveer dezelfde mate) zijn vertegenwoordigd. Secretaresse wordt dus echt als vrouwenberoep gezien, ook al heeft een man daarvoor ook de juiste opleidingskwalificatie.

Het omgekeerde verhaal geldt bijvoorbeeld voor de beroepsklasse van vertegenwoordigers en artsenbezoekers. Terwijl geen enkele vrouw die de HBO-opleiding diëtetiek heeft gevolgd dit beroep uitoefent, is maar liefst $18 \%$ van de mannen met deze opleidingskwalificatie artsenbezoeker of vertegenwoordiger. Vertegenwoordiger zijn is dus blijkbaar 'mannenwerk'.

Bovendien is op basis van de beroepengegevens uit de AKT 1985 nagegaan of er een verschil tussen beide sexen bestaat in het procentuele aandeel dat, met één van de vrouwenopleidingen als opleidingskwalificatie, een hogere leidinggevende functie heeft. Van alle mannen die een vrouwenopleiding hebben genoten, heeft, gemiddeld over al deze vrouwenopleidingen, 1,7 procent een hogere leidinggevende baan. Bij de vrouwen geldt hiervoor een percentage van 0,5. 
Het lukt mannen dus beter om met deze opleidingskwalificaties een leidinggevende functie te verwerven, dan vrouwen die dezelfde opleidingen hebben gevolgd.

Zoals reeds is geconstateerd in het hoofdstuk over de opleidings- en beroepssegregatie kunnen de beroepsverschillen tussen mannen en vrouwen niet geheel worden toegeschreven aan de zogenaamde 'voorsortering' in het onderwijs. Ook al hebben mannen en vrouwen dezelfde opleiding gevolgd, dan nog komen mannen blijkbaar in andere (lees: hogere, beter betaalde, invloedrijkere) functies terecht dan hun vrouwelijke studiegenoten.

In paragraaf 6.3. en 6.4. wordt een aantal arbeidsmarktkenmerken weergegeven van de beroepsbeoefenaren die een vrouwenopleiding als opleidingskwalificatie hebben. Naast prognoses over de vraag naar en het aanbod van mensen met een 'vrouwelijke' onderwijskwalificatie, is een aantal arbeidsmarktaspecten onderscheiden, die evenals de prognoses opgevat kunnen worden als 'risico-indicatoren' voor (de huidige en toekomstige) beroepsbeoefenaren met een bepaalde opleidingskwalificatie. Al deze arbeidsmarktkenmerken en prognoses geven een bepaald aspect van dit arbeidsmarktrisico weer. De prognoses hebben betrekking op de nabije toekomst (1989-1994), terwijl de andere indicatoren betrekking hebben op het recente verleden.

Tussen de beroepsbeoefenaren met een 'vrouwelijke' onderwijskwalificatie blijken, meer dan bij de werkenden in vrouwenberoepen, grote verschillen te bestaan. De arbeidsmarktprognoses en kenmerken van deze beroepsbeoefenaren kan men mede daarom ook beter niet vergelijken met de gemiddelden over alle beroepsbeoefenaren. Het is wel zinvol om hun arbeidsmarktkarakteristieken te vergelijken met de gemiddelden over het totaal van werkende LBO-ers, MBO-ers en HBO-ers. Over het algemeen kan men stellen, dat de arbeidsmarktkarakteristieken van degenen die met een vrouwenopleiding als opleidingskwalificatie werkzaam zijn, overeenkomen met de arbeidsmarktkarakteristieken van degenen die een overeenkomstig opleidingsniveau hebben.

\subsection{Arbeidsmarktperspectieven vrouwenopleidingen}

Anders dan bij de beschrijving van de werkenden in vrouwenberoepen, zullen bij de vooruitzichten voor (aankomende) beroepsbeoefenaren met 'vrouwelijke' opleidingskwalificaties niet alleen de middellange termijn ontwikkelingen aan de vraagzijde worden geprognosticeerd, maar tevens de ontwikkelingen aan de aanbodzijde. Het arbeidsmarktperspectief voor mensen die een bepaalde opleiding hebben genoten, hangt immers niet alleen af van de hoeveelheid banen die voor deze mensen vrijkomen (de job-openings), doch echter ook van het aantal mensen dat met de betreffende opleidingskwalificatie om deze banen concurreert (in casu de schoolverlaters en de werklozen die minder dan één jaar werkloos zijn) $)^{63}$.

63. Zie voor een verdere beschrijving van het berekenen van de uitbreidings-, vervangings- en totale vraag De Grip, Heijke en Dekker (1989). 
Tabel 33. Procentuele groei van de uitbreidings-, vervangings- en totale vraag in de periode 1989-1994 per vrouwenopleiding

\begin{tabular}{|c|c|c|c|c|c|c|c|}
\hline \multirow[b]{2}{*}{ Code } & \multirow[b]{2}{*}{ Opleidingstype } & \multicolumn{2}{|c|}{ Uitbreidingsvraag } & \multicolumn{2}{|c|}{ Vervangingsvraag } & \multicolumn{2}{|c|}{ Totale vraag } \\
\hline & & $\%$ & typering & $\%$ & typering & $\%$ & typering \\
\hline 7 & LBO Economisch \& Administratief & -22 & zeer laag & 11 & hoog & 11 & gemiddeld \\
\hline \multirow[t]{2}{*}{8} & LBO Sociale Verzorging \& Horeca & 3 & laag & 15 & zeer hoog & 18 & hoog \\
\hline & Gemiddelde LBO & 1 & laag & 12 & hoog & 13 & gemiddeld \\
\hline 16 & MBO Verpleging & 9 & gemiddeld & 12 & hoog & 21 & hoog \\
\hline 17 & MBO Medisch Laboratorium & 10 & hoog & 11 & hoog & 21 & hoog \\
\hline 18 & MBO Ziekenverzorging & 10 & hoog & 14 & zeer hoog & 24 & hoog \\
\hline \multirow[t]{2}{*}{22} & MBO Sociale Verzorging & 11 & hoog & 18 & zeer hoog & 29 & zeer hoog \\
\hline & Gemiddelde MBO & 16 & zeer hoog & 8 & gemiddeld & 24 & hoog \\
\hline 33 & HBO Verpleging \& Therapie & 8 & gemiddeld & 4 & zeer laag & 12 & gemiddeld \\
\hline 34 & HBO Medisch Laboratorium & 8 & gemiddeld & 9 & gemiddeld & 18 & hoog \\
\hline \multirow[t]{2}{*}{35} & HBO Diëtetiek & 9 & gemiddeld & 4 & zeer laag & 13 & gemiddeld \\
\hline & Gemiddelde HBO & 10 & hoog & 6 & laag & 16 & gemiddeld \\
\hline
\end{tabular}

Bron: $\mathrm{CBS} / \mathrm{ROA}$

Wat betreft de uitbreidingsvraag luidt de belangrijkste conclusie als volgt: in vergelijking met de gemiddelde vraag naar personen met respectievelijk een LBO-, MBO- of HBO-kwalificatie, is de vraag naar mensen met een typische vrouwenopleiding verhoudingsgewijs aan de lage kant. Dit geldt voor alle drie de opleidingsniveaus.

Uitgezonderd het HBO-niveau, blijkt de vervangingsvraag onder mensen met een 'vrouwelijke' opleidingsachtergrond hoger te zijn dan gemiddeld voor het LBO- en MBO-niveau geldt. De zeer lage vervangingsvraag bij de HBO-opleidingen Verpleging, Fysiotherapie en Diëtetiek lijkt enerzijds het gevolg van het feit dat het hier deels gaat om relatief jonge opleidingen (en beroepen), zodat de betreffende beroepsbeoefenaren meestal nog niet toe zijn aan vervanging. Anderzijds blijken er juist in de beroepen waar mensen met deze opleidingskwalificaties in terechtkomen veel mogelijkheden te bestaan voor het werken in deeltijd. In dit onderzoek wordt niet in de vervangingsvraag, doch in de uitbreidingsvraag gemeten of er een baan vrijkomt nadat iemand in deeltijd is gaan werken. Anders dan mensen (vrouwen) met een opleidingskwalificatie op LBO- of MBO-niveau, die zich vaak in het geheel terugtrekken van de arbeidsmarkt, blijken degenen die een HBO-opleiding hebben genoten vaker een full-time baan voor een part-time baan te verruilen bij de geboorte van het (eerste) kind.

De totale vraag naar personen met een 'vrouwelijke' opleidingsachtergrond blijkt, op LBO- en MBO-niveau mede door de hoge vervangingsvraag, in grote lijnen overeen te komen met de totale vraag naar respectievelijk LBO-ers, MBO-ers en HBO-ers. Als op termijn ook vrouwen met een LBO- of MBO-kwalificatie op de arbeidsmarkt blijven nadat zij kinderen hebben gekregen, dan kan dit voor de totale vraag naar typische 'vrouwenkwalificaties' een probleem gaan vormen (zie ook hoofdstuk 5 over vrouwenberoepen). Indien tegen die tijd aan de vraagzijde niets is veranderd, zal aan de aanbodzijde gereageerd moeten gaan worden. 
Tabel 34. Procentuele groei van de instroom op de arbeidsmarkt en het arbeidsmarktperspectief in de periode 1989-1994 per vrouwenopleiding

\begin{tabular}{|c|c|c|c|c|c|}
\hline Code & Opleidingstype & $\begin{array}{l}\text { Instroom } \\
\%\end{array}$ & typering & $\begin{array}{l}\text { Perspectief } \\
\text { score }\end{array}$ & typering \\
\hline 7 & LBO Economisch \& Administratief & 22 & laag & 1,45 & slecht \\
\hline \multirow[t]{2}{*}{8} & LBO Sociale Verzorging \& Horeca & 9 & zeer laag & 0,99 & goed \\
\hline & Gemiddelde LBO & 10 & zeer laag & 1,1 & redelijk \\
\hline 16 & MBO Verpleging & 34 & laag & 1,14 & redelijk \\
\hline 17 & MBO Medisch Laboratorium & 17 & laag & 1,01 & goed \\
\hline 18 & MBO Ziekenverzorging & 34 & laag & 1,10 & redelijk \\
\hline \multirow[t]{2}{*}{22} & MBO Sociale Verzorging & 49 & gemiddeld & 1,19 & matig \\
\hline & Gemiddelde MBO & 25 & laag & 1,1 & redelijk \\
\hline 33 & HBO Verpleging \& Therapie & 61 & hoog & 1,47 & slecht \\
\hline 34 & HBO Medisch Laboratorium & 16 & laag & 1,00 & goed \\
\hline \multirow[t]{2}{*}{35} & HBO Diëtetiek & 69 & hoog & 1,54 & slecht \\
\hline & Gemiddelde HBO & 28 & laag & 1,3 & matig \\
\hline
\end{tabular}

Bron: CBS/ROA

Om na te gaan of bij de vrouwenopleidingen juist een kans op absorptie- of schaarsteproblemen bestaan, is voor iedere vrouwenopleiding het toekomstig arbeidsmarktperspectief bepaald. Hierbij wordt per opleidingstype een confrontatie gemaakt van de verwachte vraag naar nieuwkomers (i.c. job-openings) en het verwachte aanbod, dat bestaat uit de verwachte instroom van schoolverlaters op de arbeidsmarkt in de periode 1989-1994 en uit het aantal werklozen met de betreffende opleidingskwalificatie die in 1990 korter dan 1 jaar werkloos zijn. De waarde 1,05 van deze indicator geeft een evenwichtssituatie aan van vraag en aanbod, aangezien de frictiewerkloosheid op $5 \%$ is gesteld ${ }^{64}$.

Voor de periode 1989-1994 verwachten we voor de medische laboratoriumopleidingen op zowel MBO- als HBO-niveau dat de instroom van schoolverlaters uit vrouwenopleidingen beduidend lager is dan het gemiddelde voor deze onderwijsniveaus. Bij de overige vrouwenopleidingen, m.u.v. LBO Sociale Verzorging, wordt de instroom van schoolverlaters op de arbeidsmarkt daarentegen hoger ingeschat dan doorgaans op de onderscheiden onderwijsniveaus geldt. Voor degenen die zich straks met een dergelijke opleidingskwalificatie willen aanbieden op de arbeidsmarkt, zal de concurrentie dus sterk toenemen.

Op dit moment taxeren (aankomende) leerlingen dikwijls hun toekomstige kansen op de arbeidsmarkt aan de hand van het huidige werkloosheidspercentage van een bepaalde opleidingskwalificatie. Het is niettemin voor een studiekeuze zinvoller om te kijken naar het arbeidsmarktperspectief op het moment van afstuderen. Hierbij moet dan niet alleen de werkgelegenheidsgroei aan de vraagzijde van de arbeidsmarkt worden beschouwd, maar tevens

64. Zie voor een verdere uiteenzetting van de indicator omtrent de toekomstige arbeidsmarktsituatie Wieling e.a. (1990). 
de instroom van de betreffende schoolverlaters op de arbeidsmarkt, alsmede de concurrerende werklozen aan de aanbodzijde.

Velen houden namelijk geen rekening met het zogenaamde 'varkenscycluseffect'. Dit effect speelt ondermeer bij de verzorgende opleidingen op LBO-niveau. Zoals uit tabel 35 in paragraaf 6.4. nog zal blijken is de afgelopen jaren het werkloosheidspercentage onder mensen met een dergelijke opleidingskwalificatie hoog geweest. Mede als reactie daarop is het aantal mensen dat met deze opleidingskwalificatie uitstroomt naar de arbeidsmarkt inmiddels erg laag, ook vergeleken andere LBO-opleidingen (zie tabel 34). Deze lage instroom op de arbeidsmarkt wordt overigens ook in de nabije toekomst verwacht. De uitbreidingsvraag voor mensen met een lagere verzorgende onderwijskwalificatie is laag, doch de vervangingsvraag is zeer hoog. In combinatie met de zeer lage instroom levert dat een goed arbeidsmarktperspectief op voor het begin van de jaren negentig.

Het omgekeerde proces speelt zich af bij de werkenden die een HBO-V- of Fysiotherapieopleiding als hoogste onderwijskwalificatie bezitten. Nu nog geldt er voor hen een laag, doch snel toenemend werkloosheidspercentage. Door de massale instroom van schoolverlaters uit het $\mathrm{HBO}-\mathrm{V}$ en de Fysiotherapie-opleidingen op de arbeidsmarkt en een niet meer dan gemiddelde werkgelegenheidsgroei zijn de arbeidsmarktperspectieven voor degenen die aan het begin van de jaren negentig deze opleidingen voltooien juist slecht.

Bij veel mensen leeft het idee, dat de kansen op (leuk) werk stijgen, naarmate iemands opleidingsniveau toeneemt. Middels het schetsen van arbeidsmarktperspectieven voor een zestigtal opleidingstypen, waarbij de ontwikkelingen aan de vraagzijde worden gekoppeld aan de situatie aan de aanbodzijde, probeert het ROA inzicht te verschaffen in de kansen op een baan voor mensen met een bepaalde opleidingskwalificatie. Wanneer de gemiddelde arbeidsmarktperspectieven op de onderscheiden onderwijsniveaus met elkaar worden vergeleken valt op, dat het hoogste opleidingsniveau, in casu het HBO, gemiddeld minder goede arbeidsmarktperspectieven heeft dan het LBO en MBO. Verder studeren levert dus niet per definitie een grotere kans op werk op!

\subsection{Actuele arbeidsmarktkenmerken vrouwenopleidingen}

Als indicator voor de huidige arbeidsmarktpositie van degenen die een bepaalde onderwijskwalificatie bezitten wordt hieronder het huidige werkloosheidspercentage gepresenteerd. 
Tabel 35. Werkloosheidspercentage ${ }^{65}$ in 1990 per vrouwenopleiding

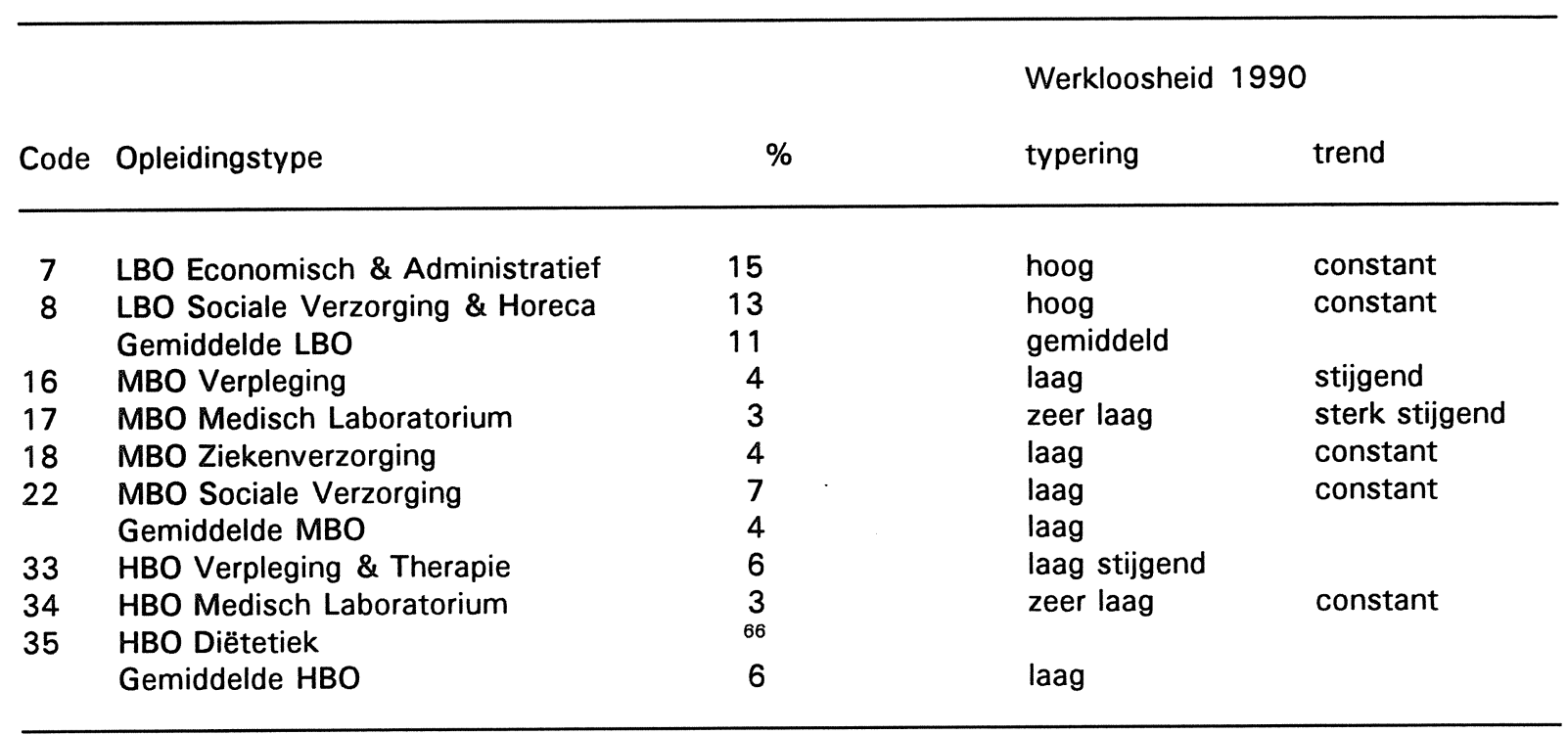

Bron: CBS/ROA

In vergelijking met mensen met een $\mathrm{MBO}$ - of $\mathrm{HBO}-\mathrm{kwalificatie,} \mathrm{die} \mathrm{gemiddeld} \mathrm{een} \mathrm{laag}$ werkloosheidspercentage kennen, zijn de LBO-ers momenteel ongeveer twee keer zo vaak werkloos. Op het MBO- en HBO-niveau hebben personen met een 'vrouwelijke' opleidingsachtergrond over het algemeen een voor dit betreffende niveau gemiddeld werkloosheidspercentage. Alleen de MBO-ers met een sociaal-verzorgende opleidingsrichting zijn vaker werkloos dan gemiddeld op het MBO-niveau gebruikelijk is, terwijl omgekeerd HBO-ers met een medische laboratoriumopleiding minder dan gemiddeld door werkloosheid worden getroffen. Op het LBO-niveau is het werkloosheidpercentage onder personen met een 'vrouwelijke' opleidingsachtergrond echter hoog, terwijl voor het totaal van LBO-ers een gemiddeld percentage geldt.

Wanneer de trend van de werkloosheid in ogenschouw wordt genomen, dan blijkt zowel op het MBO- als HBO-niveau bij de verpleegkundige opleidingen de werkloosheid de werkloosheid in de periode 1987-1990 behoorlijk te zijn toegenomen. Bovendien kent het middelbare medisch laboratorium onderwijs een sterke werkloosheidstoename.

65. Het werkloosheidspercentage is berekend als het aantal werklozen in 1990 met opleiding $X$, gedeeld door de som van het aantal geregistreerde werklozen in 1990 en het aantal werkzame personen in 1989 met opleiding $X$, maal $100 \%$.

66. In de werkloosheidsbestanden van het GAB is de HBO-opleiding Diëtetiek ondergebracht bij het HBO-V, Fysiotherapie e.d. Deze bestanden zijn als uitgangspunt genomen bij de berekening van het werkloosheidspercentage. 
$-56-$

Tabel 36. Beroepen- en Branchespreiding tussen 1979-1985 per vrouwenopleiding

\begin{tabular}{|c|c|c|c|c|c|c|c|}
\hline Code & Opleidingstype & \multicolumn{2}{|c|}{ Beroepenspreiding } & trend & $\begin{array}{l}\text { Branch } \\
\text { score }\end{array}$ & $\begin{array}{l}\text { espreiding } \\
\text { typering }\end{array}$ & trend \\
\hline 7 & LBO Economisch \& Administratief & 0,91 & groot & constant & 0,91 & groot & constant \\
\hline 8 & LBO Sociale Verzorging \& Horeca & 0,91 & groot & constant & 0,89 & groot & constant \\
\hline & Gemiddelde LBO & 0,79 & gemiddeld & & 0,78 & gemiddeld & \\
\hline 16 & MBO Verpleging & 0,51 & klein & stijgend & 0,41 & klein & constant \\
\hline 17 & MBO Medisch Laboratorium & 0,67 & gemiddeld & stijgend & 0,69 & gemiddeld & constant \\
\hline 18 & MBO Ziekenverzorging & 0,37 & zeer klein & stijgend & 0,45 & klein & sterk stijgend \\
\hline 22 & MBO Sociale Verzorging & 0,86 & groot & constant & 0,83 & groot & constant \\
\hline & Gemiddelde MBO & 0,75 & gemiddeld & & 0,67 & gemiddeld & \\
\hline 33 & HBO Verpleging \& Therapie & 0,29 & zeer klein & dalend & 0,33 & zeer klein & dalend \\
\hline 34 & HBO Medisch Laboratorium & 0,64 & klein & stijgend & 0,35 & zeer klein & dalend \\
\hline 35 & HBO Diëtetiek & 0,55 & klein & stijgend & 0,54 & klein & stijgend \\
\hline & Gemiddelde HBO & 0,71 & gemiddeld & & 0,68 & gemiddeld & \\
\hline
\end{tabular}

Bron: CBS/ROA

Voor het bepalen van de arbeidsmarktpositie van vrouwenopleidingen is het tevens van belang dat men inzicht heeft in de uitwijkmogelijkheden die de schoolverlaters op de arbeidsmarkt hebben. Een opleiding die veel uitwijkmogelijkheden heeft is immers minder kwetsbaar voor schommelingen op de arbeidsmarkt dan een opleiding die deze mogelijkheden niet heeft. De indicatoren voor de beroepen- en branchespreiding geven aan of men met een bepaalde opleiding in juist enkele of een heel scala van beroepsklassen en branches terecht komt. Als spreidingsmaatstaf is gekozen voor de Gini-Hirschmann coëfficiënt, welke een waarde van 0 aanneemt wanneer alle personen met een bepaalde opleidingskwalificatie in én beroep of branche zijn geconcentreerd en de waarde 1 wanneer deze personen gelijkmatig zijn gespreid over alle branches en beroepsklassen. De beroepen- en branchespreiding hebben overigens betrekking op de gerealiseerde uitwijkmogelijkheden en niet op de potentiële.

Er blijken grote overeenkomsten te bestaan tussen de waarden voor de branche- en die voor de beroepenspreiding. Dit is mede een gevolg van het feit dat de gebruikte CBSBeroepenclassificatie in grote lijnen de indeling in bedrijfsklassen volgt. Bij de beroepenspreiding geldt tevens, wat betreft de vrouwenopleidingen zelfs in versterkte mate, dat bij een stijging van het onderwijsniveau de spreiding licht afneemt. Bij de branchespreiding is deze relatie in het algemeen niet zo eenduidig, al lijkt dit voor degenen die een 'vrouwelijke' opleidingskwalificatie hebben genoten in een belangrijke mate wel op te gaan. Op het LBO-niveau blijken de werkenden met een 'vrouwelijke' opleidingsachtergrond in een ruimer scala van beroepen en branches terecht te komen, dan gemiddeld op het LBO-niveau geldt. Op het MBO- en HBOniveau is van het omgekeerde sprake; beroepsbeoefenaren met een 'vrouwelijke' opleidingsachtergrond blijken, op één uitzondering na, een kleinere beroepen- en branchespreiding te kennen, dan de werkenden gemiddeld op het MBO- en HBO-niveau. De uitzondering betreft beroepsbeoefenaren met middelbare sociaal-verzorgende kwalificaties, die zowel over veel beroepsklassen, als branches verspreid zijn. Overigens neemt de 
beroepenspreiding bij bijna alle werkenden met een 'vrouwelijke' opleidingsachtergrond op MBOof HBO-niveau toe. Bij de branchespreiding is de trend tussen 1979 en 1985 minder eenduidig geweest.

Tabel 37. Gemiddeld functieniveau en procentuele onderbenutting in 1985 per vrouwenopleiding

\begin{tabular}{|c|c|c|c|}
\hline Code & Opleidingstype & Functieniveau & Onderbenutting (\%) \\
\hline 7 & LBO Economisch \& Administratief & 3,0 & 36 \\
\hline \multirow[t]{2}{*}{8} & LBO Sociale Verzorging \& Horeca & 2,4 & 67 \\
\hline & Gemiddelde LBO & 2,9 & 47 \\
\hline 16 & MBO Verpleging & 4,6 & 15 \\
\hline 17 & MBO Medisch Laboratorium & 4,2 & 12 \\
\hline 18 & MBO Ziekenverzorging & 3,7 & 22 \\
\hline \multirow[t]{2}{*}{22} & MBO Sociale Verzorging & 3,3 & 61 \\
\hline & Gemiddelde MBO & 3,8 & 43 \\
\hline 33 & HBO Verpleging \& Therapie & 5,2 & 6 \\
\hline 34 & HBO Medisch Laboratorium & 4,8 & 17 \\
\hline \multirow[t]{2}{*}{35} & HBO Diëtetiek & 5,1 & 32 \\
\hline & Gemiddelde HBO & 5,3 & 23 \\
\hline
\end{tabular}

Bron: CBS/ROA

De voorgaande risico-indicatoren omtrent werkloosheid en branche-en beroepenspreiding geven slechts inzicht in de mate waarin de arbeidsmarkt schoolverlaters absorbeert. Daarnaast is het van belang om te weten wat voor een soort functies mensen met een bepaalde (vrouwen)opleiding vervullen en of deze functies aansluiten bij de verworven opleidingskwalificatie. Vandaar dat is gekeken naar de mate waarin benuttingsproblemen voorkomen bij degenen die met een vrouwelijke onderwijskwalificatie werkzaam zijn.

Om de onderbenuttingsgraad te kunnen berekenen is eerst het functieniveau bepaald, waarbij gebruik is gemaakt van de score die Huijgen op basis van de beroepenclassificatie van ARBVO toekent aan de verschillende CBS-beroepsgroepen ( $3 \mathrm{e}$ digitniveau). Deze niveauscore kan waarden aannemen tussen 1 voor het meest eenvoudige werk en 7 voor werk op academisch niveau. Het functieniveau betreft het gewogen gemiddelde van de functieniveaus voor alle beroepsbeoefenaren met een bepaalde 'vrouwelijke' opleidingskwalificatie. Vervolgens is voor iedere (vrouwen)opleiding nagegaan of het niveau van de huidige functie (i.c. CBSberoepsgroep) in overeenstemming is met het gevolgde opleidingsniveau ${ }^{67}$. Een op deze wijze berekende onderbenuttingsgraad van $36 \%$ wil dus zeggen, dat $36 \%$ van de beroepsbeoefenaren met die betreffende opleidingsachtergrond in de huidige functie wordt onderbenut. $\mathrm{Er}$ is overigens niet gecorrigeerd voor mensen die worden overbenut.

67. In navolging van Huijgen (1989) ligt die grens voor het HBO bij 4.5, voor het MBO bij 3,5 en voor het LBO bij 2,5. 
Zoals verwacht, stijgt het gemiddelde functieniveau bij het toenemen van het genoten onderwijsniveau. Ten aanzien van de vrouwenopleidingen is niet een algemene conclusie te formuleren. Op het LBO-niveau vervullen personen met een economisch en/of administratieve opleiding beroepen met een, voor dit onderwijsniveau, gemiddeld functieniveau. Beroepsbeoefenaren met een LBO Sociale Verzorging \& Horeca als onderwijskwalificatie hebben daarentegen een aanzienlijk lager dan gemiddeld functieniveau voor LBO-ers.

Beroepsbeoefenaren met een vrouwenopleiding op MBO-niveau blijken in drie van de vijf gevallen een aanzienlijk hoger gemiddeld functieniveau te hebben dan gemiddeld op dit onderwijsniveau. Voor degenen die een middelbare sociaal-verzorgende opleidingskwalificatie hebben geldt daarentegen een veel lager dan gemiddeld functieniveau.

De HBO-ers met een 'vrouwelijke' opleidingsachtergrond blijken gemiddeld allemaal een functieniveau te hebben dat enigszins lager is dan het gemiddelde voor alle werkenden met een HBO-kwalificatie. Dit geldt het sterkste voor degenen die medisch laboratorium onderwijs hebben gevolgd.

De verschillen in onderbenutting blijken, zoals verwacht, in grote lijnen de discrepanties in functieniveau te volgen. Op het LBO- en MBO-niveau worden dus met name de werkenden met een sociaal-verzorgende opleidingsachtergrond onderbenut. Op het HBO-niveau blijken de beroepsbeoefenaren die de opleiding Diëtetiek hebben gevolgd de meeste onderbenuttingsproblemen te hebben, hoewel zij gemiddeld niet het laagste functieniveau hebben. Beroepsbeoefenaren met andere dan de drie hierboven genoemde 'vrouwelijke' opleidingskwalificaties blijken een beduidend lager onderbenuttingspercentage te hebben, dan gemiddeld gebruikelijk is op respectievelijk het LBO-, MBO- en HBO-niveau.

Voort is opvallend, dat met het toenemen van het onderwijsniveau de onderbenutting afneemt; namelijk van $47 \%$ gemiddeld op LBO-niveau tot $23 \%$ op HBO-niveau. Dit kan mede een gevolg zijn van het verdringingsproces. Hoger opgeleiden verdringen de lager opgeleiden hierbij uit de functies die voorheen ook door de lager opgeleiden werden vervuld. Hoe lager men is opgeleid, des te meer men door deze verdringing wordt getroffen en des te groter de kans dat men wordt onderbenut.

Bovendien duidt een lage onderbenuttingsgraad in combinatie met een kleine beroepen- en branchespreiding op opleidingen die voorbereiden op een geprofessionaliseerd arbeidsmarktsegment zoals bijvoorbeeld de gezondheidszorg en het onderwijs. Dit zijn deelmarkten waar een sterke regulering bestaat met betrekking tot de beroepsintrede: concurrentie vanuit andere aanbodscategorieën is vaak bij wet verboden. Dergelijke opleidingen, zoals de meeste vrouwenopleidingen op MBO- en HBO-niveau, hebben in dat opzicht een sterke marktpositie, maar zijn daarentegen wel kwetsbaar voor schommelingen in de vraagaanbodverhoudingen op de arbeidsmarkt.

Samenvattend kan men stellen, dat over het algemeen geldt dat er meer arbeidsmarktverschillen 
zijn tussen de werkenden met 'vrouwelijke' onderwijskwalificaties onderling, dan tussen werkenden met een vrouwenopleiding en beroepsbeoefenaren met andere onderwijskwalificaties. Dit geldt in nog sterkere mate als de onderscheiden vrouwenopleidingen vergeleken worden met bijbehorende gemiddelden op respectievelijk LBO-, MBO- en HBO-niveau. De belangrijkste verschillen tussen vrouwenopleidingen en andere opleidingskwalificaties blijken de nabije toekomst te betreffen.

Zo wordt de werkgelegenheidsgroei voor kwalificaties die men met typische vrouwenopleidingen kan behalen lager ingeschat, dan die gemiddeld voor andere opleidingskwalificaties. Door de huidige verhoudingsgewijs hoge vervangingsvraag bij beroepsbeoefenaren met 'vrouwelijke' onderwijsprofielen is de totale vraag naar 'vrouwelijke' opleidingskwalificaties toch vergelijkbaar met de gemiddelden op LBO-, MBO- en HBO-niveau.

Deze verhouding tussen de (lage) uitbreidingsvraag en (hoge) vervangingsvraag bij de werkenden met een 'vrouwelijke' opleidingsachtergrond dient men wel in de gaten te houden bij een eventueel veranderende arbeidsmarktparticipatie van vrouwen (ouders) bij de geboorte van het (eerste) kind. Met name op het LBO- en MBO-niveau is de (zeer) lage toekomstige instroom van schoolverlaters die een vrouwenopleiding hebben genoten, ook in vergelijking met de gemiddelde instroom op deze beide onderwijsniveaus, nogal opvallend. In combinatie met het gegeven, dat de instroom op het HBO-niveau juist bij de 'vrouwenopleidingen zo hoog is, lijkt dit het gevolg te zijn van het feit, dat vrouwen in snel tempo hun onderwijsachterstand aan het inhalen zijn.

Tot slot volgt per opleidingsniveau nog een algemene vergelijking tussen de beroepsbeoefenaren die een vrouwenopleiding als hoogst genoten opleidingskwalificatie hebben.

Op LBO-niveau zijn er wat betreft de arbeidsmarktpositie in het recente verleden slechts geringe verschillen tussen de sociaal-verzorgende en economisch-administratieve richting. Beiden kennen momenteel een hoge werkloosheid, een grote beroepen- en branchespreiding. Bovendien verwachten we voor beiden voor de nabije toekomst een hoge tot zeer hoge vervangingsvraag en een lage instroom van schoolverlaters op de arbeidsmarkt. Degenen die een lagere sociaalverzorgende opleidingsachtergrond hebben worden op dit moment nogal vaak onderbenut, maar voor (aankomende) beroepsbeoefenaren met een dergelijke opleidingsachtergrond geldt wel een goed arbeidsmarktperspectief. Omgekeerd hebben werkenden met LBO Economisch \& Administratief, door met name een zeer negatieve uitbreidingsvraag een slecht perspectief, maar zij worden daarentegen op dit moment wel minder vaak onderbenut.

Terwijl de beroepsbeoefenaren die andere vrouwenopleidingen op MBO-niveau hebben voltooid, een lage, voor het MBO gemiddelde, werkloosheid hebben, een (relatief) kleine beroepen- en branchespreiding kennen, een relatief hoog functieniveau hebben, zodat verhoudingsgewijs weinigen worden onderbenut, alsmede bij hen een lage instroom van schoolverlaters wordt verwacht, geldt voor de werkenden met de MBO-richting Sociale Verzorging het omgekeerde. Met andere woorden: een relatief hoge werkloosheid, een grote beroepen- en branchespreiding, 
een laag functieniveau en (dus) een hoog onderbenuttingspercentage, alsmede een niet lage, doch gemiddelde instroom van schoolverlaters. Ondanks de zeer hoge totale vraag naar sociaalverzorgende MBO-ers leidt de (relatief) hoge instroom bij hen tot een matig arbeidsmarktperspectief, terwijl de andere 'vrouwelijke' MBO-opleidingen een redelijk tot goed arbeidsmarktperspectief hebben.

Op het HBO-niveau zijn het HBO-V, Fysiotherapie en Diëtetiek in eniger mate verwant voor wat betreft een aantal arbeidsmarktkarakteristieken. Dit geldt met name voor de ontwikkelingen in de nabije toekomst. Zij kennen beiden namelijk een zeer lage vervangingsvraag en een zeer hoge instroom van schoolverlaters in de periode 1989-1994. Samen met een slechts gemiddelde uitbreidingsvraag leiden beide aspecten tot een slecht arbeidsmarktperspectief. Het hogere medische laboratoriumonderwijs daarentegen heeft het goede arbeidsmarktperspectief in eerste instantie te danken aan de lage instroom van schoolverlaters in de prognoseperiode, alsmede aan de zeer lage huidige werkloosheid. 
$-61-$

\section{BESLUIT}

In dit werkdocument hebben de verschillen tussen mannen en vrouwen voor wat betreft de aansluiting tussen het door hen genoten onderwijs en hun arbeidsmarktpositie centraal gestaan. Deze aansluiting is in een aantal deelaspecten uiteengelegd. Aan de ene kant zijn trends in de uitstroom uit verschillende opleidingsniveaus en -richtingen beschreven, waarbij met name is gelet op discrepanties tussen beide sexen. Aan de andere kant is een aantal kenmerken van de arbeidsmarkt beschreven, die een goede indicator vormen voor het signaleren van sexediscrepanties op de arbeidsmarkt. Tenslotte zijn enkele arbeidsmarktkarakteristieken en perspectieven aangegeven voor degenen die in typische vrouwenberoepen of met een typisch 'vrouwelijke' opleidingskwalificatie werkzaam zijn.

We hebben kunnen constateren dat vrouwen, hoewel zij hun onderwijsachterstand naar niveau sterk aan het inlopen zijn, nog steeds andere opleidingsrichtingen kiezen dan mannen. Vrouwen zijn oververtegenwoordigd in de algemene, verzorgende en economisch-administratieve richtingen, terwijl mannen vaker in een technische of agrarische richting zijn afgestudeerd. Een belangrijk deel van de beroepssegregatie tussen beide sexen kan worden toegeschreven aan hun verschillen in deze 'voorsortering'. Echter, er is ook geconstateerd, dat mannen en vrouwen bij een gelijke opleidingskwalificatie op de arbeidsmarkt naar verschillende beroepen doorstromen. Er blijken namelijk typische vrouwen- en mannenberoepen te bestaan.

Uit de analyse van zowel sexeverschillen op de arbeidsmarkt, als de karakteristieken van de belangrijkste vrouwenberoepen en vrouwenopleidingen blijkt, dat de arbeidsmarktpositie van vrouwen over het algemeen minder goed is dan die van mannen en dat hierin de afgelopen jaren nauwelijks verandering is gekomen. Zo hebben vrouwenberoepen, ook in vergelijking met hun functieniveau, een laag maatschappelijk aanzien, werken vrouwen relatief vaak in deeltijd en zijn ze minder vaak als zelfstandig ondernemer actief. Bovendien weten mannen, ook wanneer is gecorrigeerd voor opleidingskwalificatie, vaker een leidinggevende functie te verwerven.

Wat betreft de nabije toekomst kan worden opgemerkt, dat er met name bij de vrouwenberoepen een risico schuilt in het (relatief) grote belang van de vervangingsvraag in de totale vraag naar nieuwkomers. Deze 'job-openings' zijn bij de vrouwenberoepen met name het gevolg van het feit, dat op grote schaal vrouwen worden vervangen door andere vrouwen. Als vrouwen in de toekomst, ook na de geboorte van kinderen, (langer) blijven participeren op de arbeidsmarkt zullen job-openings als gevolg van de vervangingsvraag afnemen. De totale vraag zal dan meer afhankelijk worden van de uitbreidingsvraag ${ }^{68}$, die voor bijna alle vrouwenberoepen gemiddeld is. Indien vrouwen in de nabije toekomst, evenals in het recente verleden, meer zullen toetreden tot de arbeidsmarkt dan mannen, dan zal in deze

68. Aangezien zowel de vervangings-, als uitbreidingsvraag in personen wordt gemeten, wordt de (halve) baan die wordt opgevuld, als iemand (meestal een vrouw) met een voltijdse baan in deeltijd gaat werken, gemeten bij de uitbreidings-i.p.v. de vervangingsvraag. Een deel van de gemeten uitbreidingsvraag betreft dus eigenlijk vervangingsvraag. 
vrouwenberoepen de concurrentie tussen vrouwen en mannen en vrouwen onderling gaan toenemen. Dat mannen meer en meer in vrouwenberoepen werkzaam zijn (terwijl vrouwen nauwelijks doordringen in mannenberoepen) is met het oog op de werkgelegenheid van vrouwen derhalve geen goede zaak.

Hoewel de verschillende aspecten van de aansluitingsproblematiek en de discrepanties hierin tussen beide sexen in dit werkdocument als afzonderlijk thema's zijn besproken, dienen we ons wel te realiseren, dat deze aspecten voor een belangrijk deel in elkaars verlengde liggen.

Bruyn-Hundt (1988) geeft in haar beschrijving van vrouwen op de arbeidsmarkt aan, dat door de feiten en verwachtingen die men heeft omtrent de lagere 'levensproduktiviteit' van vrouwen, zij een minder goede arbeidsmarktpositie kunnen en willen verwerven. Immers, doordat vrouwen (tussentijds) hun loopbaan onderbreken om zich meer aan de taken binnenshuis te wijten, zijn werkgevers evenals deze vrouwen zelf vaak niet bereid om in hen evenveel te 'investeren' als in mannen. Mannen volgen dus vaker aanvullende scholing en kunnen makkelijker doorstromen naar hogere functies. Bij dit proces spelen niet alleen het feitelijk gedrag, maar vooral ook de beeldvorming over mannen en vrouwen een belangrijke rol.

Als aanvulling hierop laten Brouns en Schokker (1990) zien, dat sexeongelijkheid in arbeidssituaties niet alleen verklaard kan worden door factoren buiten de arbeidsmarkt, zoals socialisatie en genoten onderwijs, of door uitsluitings- en segmenteringsprocessen op de arbeidsmarkt. Ook factoren die betrekking hebben op de arbeidsorganisatie en het werk zelf zijn belangrijke oorzaken van sexediscrepanties in het arbeidsproces.

Aan de ene kant kan worden gesteld, dat vrouwen een minder goede arbeidsmarktpositie hebben omdat zij minder participeren in het arbeidsproces. Aan de andere kant is het even goed zo dat vrouwen juist doordat zij de minder aantrekkelijke banen vervullen, eerder geneigd zijn minder aan het arbeidsproces deel te nemen. Wil men deze vicieuze cirkel doorbreken, dan dient het beleid dus enerzijds gericht te zijn op het verhogen van de arbeidsmarktparticipatie en anderzijds op het creëren van behoorlijke banen en loopbaanperspectieven voor vrouwen. De taakverdeling binnenshuis tussen beide sexen kan daarbij uiteraard niet buiten schot blijven. 


\section{LITERATUUR}

Boot, P.A., Her- en bijscholing van werkenden; een inleiding, in: Tijdschrift voor Politieke Ekonomie, 1989/3, blz. 93-113, Stichting Politieke Ekonomie, Amsterdam.

Bruijn, J. de, Kwaliteit van de vrouwenarbeid, in: Tijdschrift voor Politieke Ekonomie, 1986/1, blz. 85-99, Stichting Politieke Ekonomie, Amsterdam.

Bruyn-Hundt, M. (1988), Vrouwen op de arbeidsmarkt, Nederlandse situatie in de jaren tachtig en negentig, Scala-reeks, Het Spectrum, Utrecht.

CBS (1981-1991), Overgangen binnen het onderwijs en intrede in de maatschappij, onderwijsmatrices 1979 - 1988, Centraal Bureau voor de Statistiek (CBS), Voorburg/Heerlen.

CBS (1982), Arbeidskrachtentelling 1979, Centraal Bureau voor de Statistiek (CBS), Voorburg/Heerlen.

CBS (1987), Arbeidskrachtentelling 1985, Centraal Bureau voor de Statistiek (CBS), Voorburg/Heerlen.

CBS (1990), Enquête Beroepsbevolking 1989, Centraal Bureau voor de Statistiek (CBS), Voorburg/Heerlen.

CBS (1991), Enquête Beroepsbevolking 1990, Centraal Bureau voor de Statistiek (CBS), Voorburg/Heerlen.

Dekker, R.J.P., A. de Grip, Th.B.J. Beekman, P.J.E. van de Loo, M.H. Wieling, E.J.T.A. Willems, Rapportage I-SEE! 1990, ROA-R-1990/6, Maastricht.

Dekker, R.J.P., A. de Grip (1990), P.J.E. van de Loo, ROA-Beroepenclassificatie 1990, ROA-W1990/9, Maastricht.

Doorne-Huiskes, A. van, Seksesegregatie op de arbeidsmarkt, in: Themabundel werken, 1987, blz. 47-56, ZUV, Groningen.

Elfring, T., R.C. Kloosterman (1989), De Nederlandse 'Jobmachine'; de snelle expansie van laagbetaald werk in de dienstensector 1979-1986, paper Ecozoek, Economisch Geografisch Instituut (EGI), Amsterdam.

Grip, A. de, J.A.M. Heijke, R.J.P. Dekker, De arbeidsmarkt naar opleiding en beroep in 1992, ROA-R-1989/8, Maastricht. 
Groot, L.F.M. (1990), De onderwijs- en beroepssegregatie tussen mannen en vrouwen in de jaren tachtig, in: Tijdschrift voor Arbeidsvraagstukken (TVA), 1990/4, blz. 4-12.

Huijgen, F. (1989), De kwalitatieve structuur van de werkgelegenheid in Nederland, deel III, bevolking in loondienst en functiestructuur in 1977 en 1985, OSA-voorstudie nr. V 33, Organisatie voor Strategisch Arbeidsmarktonderzoek (OSA), Den Haag.

Kiewit, J.G. de, C.N. Teulings, Afbakening van beroepsdeelmarkten voor een aantal sectoren, SEO-Research Memorandum 9001, Stichting voor Economisch Onderzoek (SEO), Amsterdam

Kuhry, B., R.M. van Opstal (1987), De arbeidsmarkt naar opleidingscategorie 1975-2000, CPBW-1987/17, Centraal Planbureau (CPB), Den Haag.

Laan, L. van der, E.R. van den Bout (1990), Een economisch-geografische analyse van de regionale verschillen in de participatie van vrouwen op de arbeidsmarkt in Nederland, Economisch-Geografisch Instituut (EGI), Rotterdam.

Lodder, B.J.H., P.J.E. van de Loo, G.W.M. Ramaekers, R.K.W. van der Velden, Arbeidsmarktindicatoren ten behoeve van het emancipatiebeleid aan de Rijksuniversiteit Limburg, ROA-R-1991/7, Researchcentrum voor Onderwijs en Arbeidsmarkt, Maastricht.

Loontechnische Dienst (1988), De positie van mannen en vrouwen in het arbeidsproces, Ministerie van Sociale Zaken en Werkgelegenheid, Den Haag.

Ministerie van Onderwijs en Wetenschappen (1990), SKILL-raming 1990-II, Tijdreeksen uit de onderwijsprognose 1990, Ministerie van Onderwijs en Wetenschappen, Zoetermeer.

Ministerie van Sociale Zaken en Werkgelegenheid (1990), Rapportage Arbeidsmarkt 1990, Ministerie van Sociale Zaken en Werkgelegenheid, Den Haag.

Mourik, A. van, J. Siegers (1988), Ontwikkelingen in de beroepssegregatie tussen mannen en vrouwen, 1971-1985, in: Economisch Statistische Berichten (ESB), 1988, blz. 732-737.

Nijssen, A.F.M., H.H.M. Peeters, A.R.M. Wennekers, Het MKB in de concurrentieslag van de jaren negentig, in: Economisch Statistische Berichten (ESB), 9-1-1991, blz. 41-44.

Ott, M. (1985), Assepoesters en kroonprinsen: een onderzoek naar de minderheidspositie van agentes en verplegers, SUA, Amsterdam.

ROA (1991), De arbeidsmarkt naar opleiding en beroep tot 1994, prototype, ROA-R-1991/5, Researchcentrum voor Onderwijs en Arbeidsmarkt, Maastricht. 
SCP (1988), Sociaal en Cultureel Rapport 1988, Sociaal Cultureel Planbureau, Rijswijk.

Siegers, J. (1979), Beroepssegregatie tussen mannen en vrouwen in Nederland, in: Economisch Statistische Berichten (ESB), 1979, blz. 208-213.

Sixma, H., W. Ultee (1983), Een beroepsprestigeschaal voor Nederland in de jaren tachtig, in: Mens en Maatschappij, 1983, jaargang 58, nr. 4, blz. 360-382.

Tijdens, K., (1989), Automatisering en vrouwenarbeid. Een studie over beroepssegregatie op de arbeidsmarkt in de administratieve beroepen en in het bankwezen, Utrecht.

Trommel, D. en E. Poutsma (1990), Nieuwe technologieën en functieverbetering voor vrouwen in de industrie, paper congres Vrouwen/Mannen, Veranderingen in maatschappelijke verhoudingen, Economisch Instituut voor het Midden- en Kleinbedrijf (EIM), Zoetermeer.

Tweede Kamer der Staten-Generaal (1984/1985), Beleidsplan Emancipatie, vergaderjaar 19841985, 19052, nrs. 1-2, Tweede Kamer der Staten-Generaal, Den Haag.

Wieling, M.H., A. de Grip, E.J.T.A. Willems, Een systematische kwalitatieve typering van arbeidsmarktinformatie, ROA-W-1990/8, Maastricht.

Willems, E.J.T.A., A. de Grip (1990), Vervangingsvraagprognoses naar beroep en opleiding, ROA-W-1990/7, Maastricht. 


\section{BIJLAGE 1. DE BELANGRIJKSTE OPLEIDINGSACHTERGRONDEN VAN DE BEROEPSBEOEFENAREN IN VROUWENBEROEPEN NAAR SEXE IN 1985 (TUSSEN HAAKJES: AANDEEL IN PROCENTEN)}

\begin{tabular}{|c|c|c|c|}
\hline \multicolumn{2}{|c|}{ Vrouwenberoep } & \multirow{2}{*}{$\begin{array}{l}\text { Mannen } \\
\text { WO Dier-, Geneeskunde, Tandheel- } \\
\text { kunde (33) } \\
\text { MBO Verpleging (18) }\end{array}$} & \multirow{2}{*}{$\begin{array}{l}\text { Vrouwen } \\
\text { MBO Verpleging (28) } \\
\text { HBO Verpleging, Fysiotherapie e.d. } \\
\text { (14) } \\
\text { MBO Sociale verzorging (13) }\end{array}$} \\
\hline 06/07 & $\begin{array}{l}\text { Verpleeg- en } \\
\text { geneeskundigen }\end{array}$ & & \\
\hline 32 & $\begin{array}{l}\text { Secretaressen, } \\
\text { Typisten }\end{array}$ & $\begin{array}{l}\text { MBO Economisch \& Administratief } \\
\text { (23) } \\
\text { MAVO, onderbouw HAVO/VWO } \\
\text { (19) } \\
\text { Bovenbouw HAVO/VWO (12) }\end{array}$ & $\begin{array}{l}\text { MBO Economisch + Administra- } \\
\text { tief (31) } \\
\text { HBO Economisch + Administratief } \\
\text { (15) } \\
\text { MAVO, onderbouw HAVO/VWO } \\
\text { (15) } \\
\text { Bovenbouw HAVO/VWO (11) } \\
\text { LBO Economisch + Administratief } \\
\text { (10) }\end{array}$ \\
\hline 38 & $\begin{array}{l}\text { Telefonisten, } \\
\text { telegrafisten }\end{array}$ & $\begin{array}{l}\text { HBO Verkeer, Vervoer + Telecom- } \\
\text { municatie (16) } \\
\text { MBO Politie-, Defensie-, Bewa- } \\
\text { kingsopleiding (14) } \\
\text { MAVO, onderbouw HAVO/VWO } \\
\text { (14) } \\
\text { Bovenbouw HAVO/VWO (13) }\end{array}$ & $\begin{array}{l}\text { MAVO, onderbouw HAVO/VWO } \\
(28) \\
\text { MBO Economisch + Administra- } \\
\text { tief (15) } \\
\text { Bovenbouw HAVO/VWO (12) }\end{array}$ \\
\hline 48 & $\begin{array}{l}\text { Winkelbedienden, } \\
\text { e.a. verkopers }\end{array}$ & $\begin{array}{l}\text { MBO Economisch + Administratief } \\
\text { (25) } \\
\text { Basisonderwijs (15) } \\
\text { MAVO, onderbouw HAVO/VWO } \\
\text { (15) } \\
\text { LBO Technisch (12) }\end{array}$ & $\begin{array}{l}\text { LBO Sociale verzorging + Horeca } \\
\text { (22) } \\
\text { Basisonderwijs (17) } \\
\text { MAVO, onderbouw HAVO/VWO } \\
\text { (16) } \\
\text { MBO Economisch + Administra- } \\
\text { tief (14) }\end{array}$ \\
\hline 54 & $\begin{array}{l}\text { Verzorgend en } \\
\text { huishoudelijk per- } \\
\text { soneel }\end{array}$ & Basisonderwijs (24) & MBO Sociale verzorging (25) \\
\hline & & $\begin{array}{l}\text { Bovenbouw HAVO/VWO (11) } \\
\text { LBO Technisch (11) }\end{array}$ & $\begin{array}{l}\text { LBO Sociale verzorging en Horeca } \\
\text { (23) } \\
\text { Basisonderwijs (21) }\end{array}$ \\
\hline 55 & $\begin{array}{l}\text { Schoonmakers, } \\
\text { conciërges }\end{array}$ & $\begin{array}{l}\text { Basisonderwijs (39) } \\
\text { LBO Technisch (20) } \\
\text { MBO Technisch (10) }\end{array}$ & $\begin{array}{l}\text { Basisonderwijs (46) } \\
\text { LBO Sociale verzorging en Horeca } \\
\text { (27) }\end{array}$ \\
\hline
\end{tabular}




\begin{tabular}{|c|c|c|c|}
\hline \multicolumn{2}{|c|}{ Vrouwenberoep } & \multirow{2}{*}{$\begin{array}{l}\text { Mannen } \\
\text { Basisonderwijs (53) } \\
\text { MBO Technisch (16) }\end{array}$} & \multirow{2}{*}{$\begin{array}{l}\text { Vrouwen } \\
\text { Basisonderwijs (38) } \\
\text { LBO Sociale verzorging + Horeca } \\
\text { (31) }\end{array}$} \\
\hline 56 & Wasserijpersoneel & & \\
\hline 57 & $\begin{array}{l}\text { Kappers, schoon- } \\
\text { heidsspecialisten }\end{array}$ & $\begin{array}{l}\text { MBO Horeca + Kappersopleiding }{ }^{1} \\
\text { (52) } \\
\text { MBO Sociale Verzorging (31) }\end{array}$ & $\begin{array}{l}\text { MBO Sociale Verzorging (47) } \\
\text { MBO Horeca- + Kappersopleiding } \\
\text { (36) }\end{array}$ \\
\hline 59 & $\begin{array}{l}\text { Dienstverlenende } \\
\text { functies n.e.g. }\end{array}$ & $\begin{array}{l}\text { Basisonderwijs (30) } \\
\text { LBO Technisch (18) } \\
\text { MBO Economisch + Administratief } \\
\text { (10) }\end{array}$ & $\begin{array}{l}\text { MBO Verpleging (42) } \\
\text { MAVO, onderbouw HAVO/VWO } \\
\text { (12) } \\
\text { Basisonderwijs (6) }\end{array}$ \\
\hline 79 & $\begin{array}{l}\text { Confectiemakers, } \\
\text { stoffeerders }\end{array}$ & $\begin{array}{l}\text { Basisonderwijs (33) } \\
\text { LBO Technisch }(25)^{2} \\
\text { MBO Technisch }(21)^{2}\end{array}$ & $\begin{array}{l}\text { LBO Sociale Verzorging + Horeca } \\
\text { (29) } \\
\text { Basisonderwijs }(24) \\
\text { MBO Technisch }(15)^{2} \\
\text { LBO Technisch }(15)^{2}\end{array}$ \\
\hline
\end{tabular}

1. Het gaat hier om (kappers)opleidingen waarmee men tevens de bevoegdheid om zich zelfstandig te vestigen kan betalen; bij de (kappers)opleidingen die vallen onder het opleidingstype MBO Sociale Verzorging kan men deze bevoegdheid niet halen!

2. Hierbij dient men zich te realiseren dat een aantal confectie-opleidingen in het leerlingwezen tot het technisch onderwijs wordt gerekend. 


\section{BIJLAGE 2. DE BELANGRIJKSTE BEROEPEN VAN BEROEPSBEOEFENAREN MET EEN VROUWENOPLEIDING ALS OPLEIDINGSACHTERGROND NAAR SEXE IN 1985 (TUSSEN HAAKJES: AANDEEL IN PROCENTEN)}

\begin{tabular}{|c|c|c|}
\hline Vrouwenopleiding & Mannen & Vrouwen \\
\hline $\begin{array}{l}\text { LBO Economisch + } \\
\text { Administratief }\end{array}$ & $\begin{array}{l}\text { Boekhoudkundige functies (22) } \\
\text { Overige administratieve functies } \\
\text { (15) } \\
\text { Winkelbedienden (7) }\end{array}$ & $\begin{array}{l}\text { Overige administratieve functies } \\
\text { (22) } \\
\text { Secretaressen, typisten (17) } \\
\text { Boekhoudkundige functies (17) } \\
\text { Winkelbedienden (16) }\end{array}$ \\
\hline $\begin{array}{l}\text { LBO Sociale Verzor- } \\
\text { ging en Horeca }{ }^{1}\end{array}$ & $\begin{array}{l}\text { Koks, kelners, serveersters (69) } \\
\text { Zelfstandige horecabedrijfhou- } \\
\text { ders (12) } \\
\text { Schoonmakers, conciërges (5) }\end{array}$ & $\begin{array}{l}\text { Huishoudelijk en verzorgend } \\
\text { personeel (19) } \\
\text { Winkelbedienden (17) } \\
\text { Schoonmakers, conciërges (13) } \\
\text { Koks, kelners, serveersters (9) }\end{array}$ \\
\hline MBO Verpleging & $\begin{array}{l}\text { Genees- en verpleegkundig } \\
\text { personeel (88) }\end{array}$ & $\begin{array}{l}\text { Genees- en verpleegkundig } \\
\text { personeel (64) } \\
\text { Dienstverlenende functies } \\
\text { n.e.g. }{ }^{2}(10) \\
\text { Huishoudelijk en verzorgend } \\
\text { personeel (7) }\end{array}$ \\
\hline $\begin{array}{l}\text { MBO Medisch } \\
\text { laboratorium }\end{array}$ & $\begin{array}{l}\text { Genees- en verpleegkundig } \\
\text { personeel }^{3}(30) \\
\text { Instrumentmakers, machine } \\
\text { bankwerker-monteurs (18) } \\
\text { Zelfstandige winkeliers (9) } \\
\text { Laboratoriumanalisten (7) }\end{array}$ & 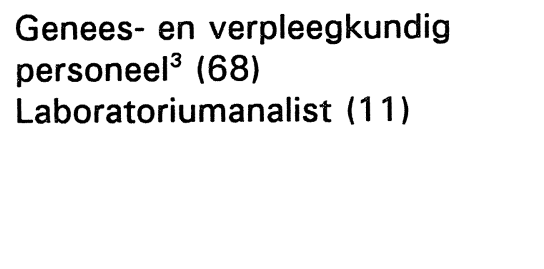 \\
\hline $\begin{array}{l}\text { MBO } \\
\text { Ziekenverzorging }\end{array}$ & $\begin{array}{l}\text { Genees- en verpleegkundig } \\
\text { personeel (82) }\end{array}$ & $\begin{array}{l}\text { Genees- en verpleegkundig } \\
\text { personeel (73) } \\
\text { Huishoudelijk en verzorgend } \\
\text { personeel (15) }\end{array}$ \\
\hline $\begin{array}{l}\text { MBO Sociale } \\
\text { Verzorging }\end{array}$ & $\begin{array}{l}\text { Genees- en verpleegkundig } \\
\text { personeel (26) } \\
\text { Kappers, schoonheidsspecialis- } \\
\text { ten (19) } \\
\text { Koks, kelners, serveersters (8) }\end{array}$ & $\begin{array}{l}\text { Huishoudelijk en verzorgend } \\
\text { personeel (33) } \\
\text { Genees- en verpleegkundig } \\
\text { personeel (19) } \\
\text { Kappers en } \\
\text { schoonheidsspecialisten (8) }\end{array}$ \\
\hline
\end{tabular}

1. In dit opleidingstype zit ook de LTS-opleiding kok/kelner begrepen.

2. Inclusief doktersassistenten.

3. Inclusief medisch laboranten. 
$-69-$

\begin{tabular}{|c|c|c|}
\hline Vrouwenopleiding & Mannen & Vrouwen \\
\hline & $\begin{array}{l}\text { Huishoudelijk en verzorgend } \\
\text { personeel (7) }\end{array}$ & Winkelbedienden (8) \\
\hline $\begin{array}{l}\text { HBO Verpleging en } \\
\text { Therapie }\end{array}$ & $\begin{array}{l}\text { Genees- en verpleegkundig } \\
\text { personeel }^{4}(87)\end{array}$ & $\begin{array}{l}\text { Genees- en verpleegkundig } \\
\text { personeel }^{4}(88)\end{array}$ \\
\hline \multirow{3}{*}{$\begin{array}{l}\text { HBO Medisch } \\
\text { laboratorium }\end{array}$} & Laboratoriumanalist (48) & Laboratoriumanalist (48) \\
\hline & $\begin{array}{l}\text { Genees- en verpleegkundig } \\
\text { personeel }^{3}(22)\end{array}$ & $\begin{array}{l}\text { Genees- en verpleegkundig } \\
\text { personeel }{ }^{3}(34)\end{array}$ \\
\hline & $\begin{array}{l}\text { Hogere schei-/natuurkundig } \\
\text { analisten (15) }\end{array}$ & $\begin{array}{l}\text { Hogere schei-/natuurkundig } \\
\text { analisten (6) }\end{array}$ \\
\hline \multirow[t]{4}{*}{ HBO Diëtetiek } & $\begin{array}{l}\text { Verpleeg-/geneeskundigen, } \\
\text { diëtisten (56) }\end{array}$ & $\begin{array}{l}\text { Verpleeg-/geneeskundigen, } \\
\text { diëtisten (68) }\end{array}$ \\
\hline & $\begin{array}{l}\text { Vertegenwoordigers, } \\
\text { artsenbezoekers (18) }\end{array}$ & Koks, kelners, serveersters (11) \\
\hline & Koks, kelners, serveersters (15) & $\begin{array}{l}\text { Dienstverlenende functies n.e.g. } \\
\text { (doktersassistenten) (6) }\end{array}$ \\
\hline & $\begin{array}{l}\text { Toezichthoudend leidinggevend } \\
\text { personeel (11) }\end{array}$ & Leerkrachten $(6)$ \\
\hline
\end{tabular}

4. Inclusief diëtisten. 


\section{INLEIDING}

In dit werkdocument staat de relatie tussen sexe en de aansluiting van de arbeidsmarkt op het onderwijs centraal. Het gaat hierbij om verschillen tussen mannen en vrouwen met betrekking tot dit aansluitingsvraagstuk, waarbij met name aandacht zal worden besteed aan ontwikkelingen die zich in de tachtiger jaren hebben afgespeeld op de arbeidsmarkt. Deze geslachtsspecifieke ongelijkheid' kan zich op de onderwijs- en arbeidsmarkt in een aantal dimensies uiten (zie ook Huijgen, 1989):

- het niveau en de richting van de behaalde opleidingskwalificaties;

- het verwerven, dan wel het verliezen van betaald werk;

- het vinden van 'passende arbeid' in relatie tot de behaalde opleidingskwalificaties (in casu de aansluiting tussen opleiding en functie);

- de mate van toegang tot bepaalde beroepen (in casu de beroepssegregatie);

- de (verticale) beroepsmobiliteit.

Bovengenoemde dimensies zullen in dit werkdocument allen aan bod komen. De positie van vrouwen op de arbeidsmarkt zal bovendien mede worden belicht aan de hand van een aantal arbeidsmarktkarakteristieken van degenen die werkzaam zijn in de belangrijkste 'vrouwenberoepen' dan wel met één van de belangrijkste 'vrouwenopleidingen' als hoogst genoten opleidingskwalificatie. Dit zijn beroepen ${ }^{2}$, c.q. opleidingstypen ${ }^{3}$, waarin vrouwen het meeste zijn oververtegenwoordigd. Ter vergelijking zullen de arbeidsmarktkenmerken van deze beroepen en opleidingen worden gerelateerd aan de gemiddelden van de betreffende arbeidsmarktkenmerken over respectievelijk alle onderscheiden beroepen en opleidingen.

Naast een aantal arbeidsmarktgegevens uit het recente verleden zullen ook de arbeidsmarktperspectieven van de onderscheiden vrouwenopleidingen en vrouwenberoepen voor de nabije toekomst worden gepresenteerd. Voor de historische data geldt dat deze in een groot aantal gevallen niet verder gaan dan 1985, aangezien de gegevens uit de Enquête Beroepsbevolking (EBB), die sindsdien de Arbeidskrachtentelling (AKT) vervangt, niet goed vergelijkbaar zijn met de data uit de AKT. Door een andere vraagstelling met betrekking tot betaald werk, is in de EBB met name het aantal personen met een kleine werkweek in vergelijking met de AKT overschat. Het gaat hier vooral om personen (vrouwen) met een kleine deeltijdbaan en schoolgaande jongeren met bijbanen. Hierdoor zijn niet alleen de gegevens over de participatiegraad sterk beïnvloed, maar eveneens gegevens over de structuur van de werkgelegenheid (zie ook

1. De in dit werkdocument te schetsen verschillen tussen mannen en vrouwen, laten uiteraard de vaak belangrijker verschillen tussen vrouwen (en mannen) onderling onverlet (zie ondermeer Van der Laan e.a., 1990).

2. Het gaat hier om de aggregatie op het 2-cijferige niveau, zoals die in de CBSBeroepenclassificatie wordt onderscheiden (in casu de beroepsklassen).

3. Het gaat hier om clusters van opleidingen, die in de Standaard Onderwijs Indeling (SOI) van het CBS op het 3-cijferige niveau worden onderscheiden. 


$$
-2-
$$

Rapportage Arbeidsmarkt 1990 van het Ministerie van Sociale Zaken en Werkgelegenheid en de CBS-publicatie over de Enquête Beroepsbevolking 1988).

Dit werkdocument heeft als primaire doel om een beschrijving te geven van de verschillen tussen mannen en vrouwen in hun aansluiting van het onderwijs naar de arbeidsmarkt. Voor een overzicht van de verklaringsgronden die hiervoor in de loop der jaren zijn aangedragen wordt ondermeer verwezen naar het trendrapport 'arbeidsvraagstukken en sexe', dat door Brouns en Schokker (1990) in opdracht van de Stimuleringsgroep Emancipatie-onderzoek (STEO) is samengesteld. Dit trendrapport bevat een uitgebreide inventarisatie en kritische evaluatie van de belangrijkste trends in het onderzoek rondom het thema arbeid en sexe.

Dit werkdocument is als volgt ingedeeld. In hoofdstuk 2 wordt aangegeven in welke mate beide sexen participeren op de arbeidsmarkt. Bij de bespreking van deze participatie wordt ook rekening gehouden met factoren als deeltijdwerk en werkloosheid. Vervolgens wordt in hoofdstuk 3 de segregatie (scheiding) tussen mannen en vrouwen voor wat betreft hun onderwijs- en beroepskeuze uiteengezet. Daarna volgt in hoofdstuk 4 een beschrijving van de Nederlandse werkgelegenheidsstructuur in de jaren tachtig, welke is gerelateerd aan de kwalificatiestructuur van de Nederlandse beroepsbevolking. De hoofdstukken 5 en 6 behandelen een aantal specifieke kenmerken van degenen die achtereenvolgens in de zogenoemde vrouwenberoepen of met een vrouwelijke opleidingskwalificatie werkzaam zijn. Het werkdocument zal in hoofdstuk 7 worden afgesloten met enkele conclusies over de relatie tussen sexe, onderwijs en arbeidsmarkt nu en in de nabije toekomst. 